\title{
The Third Space \\ Terminal Architecture and the Territory of the In-Between
}

\author{
Sean J. Solowski
}

A thesis submitted to the Faculty of Graduate Studies and Research in partial fulfillment of the requirements for the degree of

Master of Architecture

M.Arch (Professional)

Sean J. Solowski (C) 2009 


$\begin{array}{ll}\begin{array}{l}\text { Library and } \\ \text { Archives Canada }\end{array} & \begin{array}{l}\text { Bibliothèque et } \\ \text { Archives Canada }\end{array} \\ \begin{array}{l}\text { Published Heritage } \\ \text { Branch }\end{array} & \begin{array}{l}\text { Direction du } \\ \text { Patrimoine de l'édition }\end{array} \\ \begin{array}{l}\text { 395 Wellington Street } \\ \text { Ottawa ON K1A 0N4 } \\ \text { Canada }\end{array} & \begin{array}{l}\text { 395, rue Wellington } \\ \text { Ottawa ON K1A 0N4 } \\ \text { Canada }\end{array}\end{array}$

Your file Votre référence ISBN: 978-0-494-47526-3

Our file Notre référence

ISBN: 978-0-494-47526-3

NOTICE:

The author has granted a nonexclusive license allowing Library and Archives Canada to reproduce, publish, archive, preserve, conserve, communicate to the public by telecommunication or on the Internet, loan, distribute and sell theses worldwide, for commercial or noncommercial purposes, in microform, paper, electronic and/or any other formats.

The author retains copyright ownership and moral rights in this thesis. Neither the thesis nor substantial extracts from it may be printed or otherwise reproduced without the author's permission.
AVIS:

L'auteur a accordé une licence non exclusive permettant à la Bibliothèque et Archives Canada de reproduire, publier, archiver, sauvegarder, conserver, transmettre au public par télécommunication ou par l'Internet, prêter, distribuer et vendre des thèses partout dans le monde, à des fins commerciales ou autres, sur support microforme, papier, électronique et/ou autres formats.

L'auteur conserve la propriété du droit d'auteur et des droits moraux qui protège cette thèse. $\mathrm{Ni}$ la thèse ni des extraits substantiels de celle-ci ne doivent être imprimés ou autrement reproduits sans son autorisation.
In compliance with the Canadian Privacy Act some supporting forms may have been removed from this thesis.

While these forms may be included in the document page count, their removal does not represent any loss of content from the thesis.
Conformément à la loi canadienne sur la protection de la vie privée, quelques formulaires secondaires ont été enlevés de cette thèse.

Bien que ces formulaires aient inclus dans la pagination, il n'y aura aucun contenu manquant.

\section{Canada}


"Architecture consists of placing something between earth and sky"

-Eero Saarinen 


\section{ABSTRACT}

This thesis investigates the role of architecture in the expression and jurisdiction of borders that define nation state. Sovereign territory exists through the circumscription of geo-physical limits and enforcement of ports of entry. Global mobility as well as external threats shape territorial boundaries into a system that is both fortified and permeable. As a result, the border space has intensified in scale and become autonomous in definition. In particular, the commercialization of aviation has shaped a unique global frontier. The airport exists as a constructed border condition that enables a simultaneous adjacency to any nation. The transitory, intermediate space of the airport territory is the focus of this thesis. This detached territory, or ' 3 rd space', presents an opportunity for unique functions and architectural expression. As a condensed convergence of diverse users, this investigation postulates the airport as a site for socio-cultural exchange. 


\section{CONTENTS}

\section{ABSTRACT \\ TABLE OF CONTENTS \\ LIST OF FIGURES \\ LIST OF APPENDICES \\ ACKNOWLEDGEMENTS}

INTRODUCTION

01.

The Boundaries of Space and the Space of Boundaries

PART 01 - BORDER TERRITORY

02.

PART $01.1 / /$ The Frontier Border

02

PART 01.2 // The Frontline Border

07

PART $01.3 / /$ The $3^{\text {rd }}$ Space

PART 02 - CASE STUDIES

14.

PART 02.1// Kansai International Airport, Bernard Tschumi Architects 14

PART 02.2 // Hajj Terminal, Skidmore, Owings and Merrill 17

PART 02.3 // Yokohama International Port Terminal, Foreign Office Architects 20

PART 03 - PROPOSED ARCHITECTURE

23.

PART 03.1// PROJECT PROPOSAL

Project Intent

Project Context and Scope

PART 03.2 // SITE AND CONTEXT

Overview

Historical Brief

Site Context

Existing Site Conditions

PART 03.3 // DESIGN

Programmatic Concept \& Organizing Hypotheses

Master Planning Concepts

PART 03.4 // ARCHITECTURAL CONCEPT

41

Generative Concepts

Theoretical Case Study

Architectural Process

Architectural Design Principles

Architectural Generation

Design Solution

PART 04 - PROJECT OVERVIEW AND CONCLUSIONS

60.

62. 


\section{LIST OF FIGURES}

Figure 1. Global Commercial Air Traffic. Source: Airports Council International <http;//www.airports.org/cda>

Figure 2. Total Worldwide Passengers. Source: Airports Council International <http://www.airports.org/cda>

Figure 3. Aaron Koblin, dir. Flight Patterns. 2005. <http://www.aaronkoblin.com/work/flightpatterns/>

Figure 4. Air Canada Route Map, Enroute Magazine.

Figure 5. U.S. - Mexico Border Crossings, 2006. Design: by author. Source: Bureau of Transportation Statistics. <http://www.bts.gov>

Figure 6. The boundaries of economic communities and trade agreements. Source: Fernando Romero/Lar, Hyperborder (New York: Princeton Architectural Press, 2008) 38.

Figure 7. All Nippon Airways (ANA) check-in security poster, Photo by author.

Figure 8. Body Scanners Installed at 10 Busiest U.S. Airports. Source: USA Today. <http://www.usatoday.com/travel/flights>

Figure 9. Screen Capture, The Terminal. dir. Steven Spielberg, Dream Works Pictures, 2004.

Figure 10. Axonometric View, Kansai International Airport, Bernard Tschumi. Event-Cities: Praxis.

Figure 11. Model Section, Kansai International Airport, Bernard Tschumi. Event-Cities: Praxis.

Figure 12. Plan, Kansai International Airport, Bernard Tschumi. Event-Cities: Praxis.

Figure 13. Perspective, Hajj Terminal. Source: SOM. <http://www.SOM.com>

Figure 14. Plan View, Hajj Terminal. Source: Adams 263.

Figure 15. Interior Perspectives, Hajj Terminal. Source: Adams 265.

Figure 16. Site Perspective, Yokohama Port Terminal. Source: Foreign Office Architects. The Yokohama Project. 301.

Figure 17. Roof and Terminal Plan, Yokohama Port Terminal. Source: Foreign Office Architects. The Yokohama Project. 36.

Figure 18. Main Entry Perspective, Yokohama Port Terminal. Source: Foreign Office Architects 315.

Figure 19. Geographic Context. Graphic by author.

Figure 20. Malton Airport. 1930s. Source: Toronto Archives. Fonds 1244. Item 4644.

Figure 21. Malton Airport. 1939. Source: Toronto Archives. Fonds 1231. Item 1141.

Figure 22. Malton Airport. 1950s. Source: Greater Toronto Airports Authority. (GTAA) Celebrating Success: GTAA 10 Year Anniversary. 10.

Figure 23. Pearson International Airport. 1965. Source: Greater Toronto Airports Authority. (GTAA) Celebrating Success: GTAA 10 Year Anniversary. 15.

Figure 24. Pearson Aiport Site. Aerial Photography, 1954-2006. Source: City of Mississauga, E-maps. <http:www.mississauga.ca/portal/services/map>.

Figure 25. Site Context. Graphic by author.

Figure 26.

Figure 27.

Pearson Airport Land Areas. Graphic by author.

Figure 28. Programmatic Layout Existing. Graphic by author.

Figure 29. Proposed Programmatic Layout. Graphic by author.

Figure 30. Terminal Space. Photo by author.

Figure 31.

Figure 32. Airside Space. Photo by author.

Groundside System. Photo by author.

Master Planning Concepts. Graphic by author.

Figure 33. VW Automated Parking. Autostadt, Wolfsburg, Germany. Source: The New York Times. Photo: Christian Charisius.

Figure 34. Eisenman Conceptual Diagram. Digital Eisenman. 32.

Figure 35. Eisenman Conceptual Diagram. Digital Eisenman. 33.

Figure 36. Eisenman Conceptual Diagram. Digital Eisenman. 36.

Figure 37. Mapping Programmatic Sequences. Graphic by author.

Figure 38. Circulation Patterns. Graphic by author.

Figure 39. Process Panel. Graphic by author. 
Figure 40. Process Model. Graphic by author.

Figure 41. Process Models. Graphic by author.

Figure 42. Process Modeling. Graphic by author.

Figure 43. Images of 3D printer. Photo by author.

Figure 44. 3D printed study models. Photo by author.

Figure 45. Fabricated Study models. Photo by author.

Figure 46. Fabricated Study models. Photo by author.

Figure 47. 3D scanning of Study models. Photo by author.

Figure 48. Aircraft Stand Sizes. Graphic by author. Source: J. Blow. Aircraft Terminals. 148.

Figure 49. Aircraft Stand Layout. Graphic by author.

Figure 50. Potential Gate Configuration. Graphic by author.

Figure 51. Exploded Perspective, Graphic by author.

Figure 52. Perspective Study. Graphic by author.

Figure 53. Undercarriage Surface of Mixed-use Facility.

Figure 54. Lee Petrie, Interview by author. Pearson International Airport, Toronto. Photo by author.

Figure 55. Peter King, Interview by author. Pearson International Airport, Toronto. Photo by author.

Figure 56. Daniel Robert Gooch, Interview by author. Canadian Airport Council Offices, Ottawa. Photo by author.

Figure 57. Steve Shaw, Interview by author. Greater Toronto Airports Authority Office, Toronto. Photo by author.

Figure 58. Renald Fortier, Interview by author. Aviation Museum, Ottawa. Photo by author.

Figure 59. David Jensen, Interview by author. Adamson Associate Architects, Toronto. Photo by author. 


\section{LIST OF APPENDICES}

Appendix 01. Interview by Author 01 - Lee Petrie Interview by Author 02 - Peter King

Interview by Author 03 - Daniel Robert Gooch

Interview by Author 04 - Steve Shaw

Interview by Author 05 - Renald Fortier

Interview by Author 06 - David Jensen

Appendix 02. Presentation Panel 01 - Geographic Context Presentation Panel 02 - Master Plan

Presentation Panel 03 - Process

Presentation Panel 04 - In-Field Terminal

Presentation Panel 05 - Program Elements

Presentation Panel 06 - Structure 


\section{ACKNOWLEDGEMENTS}

The completion of this research is made possible through a variety of contributors and support from many individuals. Lee Petrie, Peter King, Daniel Robert Gooch, Steve Shaw, Renald Fortier, and David Jensen provided invaluable feedback and unique insight. Their willingness, cooperation and time was a meaningful contribution to this research. The financial support from the Ontario Graduate Scholarship Program provided the means to allow a rigorous and comprehensive research process. Additionally, the support from the Carleton School of Architecture faculty and, in particular, professor Stephen Fai has assisted in the thread of research and process of investigation. The consistent encouragement from friends and family provided the most significant pillar of support during this undertaking. Thanks for championing the cause! And lastly, thanks Dad for providing that resonating mantra -- l've tried not to let school get in the way of my education. I hope this document can be some testament to that. 


\section{INTRODUCTION}

\section{The Boundaries of Space and the Space of Boundaries}

Borders delineate territory. The nature of organized space lies in the formation of boundaries. 'Place' is often understood relative to its clarity of perimeter as it precisely distinguishes between an inside and an outside. From the perspective of territorial borders, the declaration of boundaries delineates ownership of property, authority of space and jurisdiction of enforcement. ${ }^{1}$ Nation-states utilize the border as an apparatus of sovereignty. In this context, borders serve to protect populations from external threats, regulate movement across state boundaries, and contribute towards the definition of a socio-political identity. ${ }^{2}$ As an interface between nations, border conditions evolve as a condition for both conflict and prosperity.

By virtue of their objectives, international boundaries enclose and define statehood as identifiable entities. The trend of globalization, however, has strained the framework of border functions and has entirely altered the traditional perception of borders as merely geopolitical in definition. The movement of people, cargo, currency and information across international boundaries is higher than any other period in history. In contrast, the demand to control and regulate border territory has never been greater. As a result of these two dialectical factors, the border must manage a complex paradox, one that demands both fortification and permeability. The logistics of this system establishes the border condition as a ' 3 rd space': an interstitial territory that manifests an autonomous identity. Detached from sovereign nation, it is a space of processing and transition. The international airport, enforced as a border condition, characterizes the phenomena of the $3^{\text {rd }}$ space within constructed limits.

This thesis researches the detached territory of the $3^{\text {rd }}$ space in the context of airport architecture. The objective is to examine the potential role of architecture in the function and expression of the $3^{\text {rd }}$ space. As a contiguous site accessible by every nation, the airport is a node of convergence and intersection. This territory is the site proposed for cultural development and architectural invention.

To achieve the appropriate architecture of international space, the research proceeds with two objectives. The first is to identify the potential function and operation within the limits of non-nation space. (What is the nature of the $3^{\text {rd }}$ space and what should operate within it?) The second is to determine the architectural expression within such a space. (What should it look like, how is this expression reached and what is the experience of the space?)

With these goals, the text begins with a contextual analysis and discussion of the $3^{\text {rd }}$ space, a historical trace of its genesis, evolution and current state. Once defined, case studies provide a conceptual frame of reference. These methods are discussed to determine their merits in relationship to the expression of the $3^{\text {rd }}$ space. Ultimately, it is argued that the functions of the international space should facilitate commingling and social interconnection.

A comprehensive site overview provides the basic framework within which an architectural approach may evolve. An additional theoretical case study is examined and discussed to situate an architectural process. Throughout the research, personal

\footnotetext{
1 John Williams, "Territorial Borders, International Ethics and Geography," Geopolitics 8.2 (2003) 25.

${ }^{2}$ Fernando Romero/Lar, Hyperborder (New York: Princeton Architectural Press, 2008) 15.
} 
interviews have been conducted with various specialists in diverse fields. By engaging in a direct dialogue with users and operators, additional insight is brought to design decisions. Finally, the architectural project combines forms devised from creative processes, factors of operational requisites and specific challenges of site conditions. Within such an approach it is argued that the appropriate architecture of international space is shaped through factors of internal nature and qualities of experience.

\title{
PART 01
}

\section{BORDER TERRITORY}

\author{
From BorderLine to BorderSpace
}

\section{PART 01.1}

\section{THE FRONTIER BORDER}

\author{
"I should tell you of the hidden [city of] Berenice, the city of the just... \\ linking a network of wires and pipes and pulleys and pistons and \\ counterweights that infiltrates like a climbing plant" \\ - Italo Calvino
}

"This is not the era of liberalization, but of vectoralization"

- McKenzie Wark

Globalization alludes to the movement and accessibility of information. Through technological connectivity, traditional concepts of boundaries have been confronted. As Mckenzie Wark appropriately points out in his essay for Mutations, the telegram was the first to redefine the notion of containment. Since that period, Wark argues, "information moves faster then people, or goods, or armies". ${ }^{3}$ The telegraph, and subsequent forms of transmitting and broadcasting, represents a virtual means of communication. Within this medium information travels along invisible vectors of no fixed origin, connecting any two places. As a consequence, Wark concludes, "The enclosure is now subordinate to the vector." 4

A global world is a vectoral world. Threads of urban infrastructure, composed of water, waste, energy, telecommunications and transport systems interconnect communities, cities and industry shaping a new geography outside the definition of geopolitical limits. These network systems distribute and accelerate the movement of information, transforming the border condition into a porous threshold.

\subsubsection{Mass Transit in the age of Commercial Aviation}

Relative to recent development in infrastructure and traffic, the aviation industry has been largely immune to market forces or world events. During an interview conducted in October 2007, Daniel Robert Gooch, director of communication at the Canadian Airports Council (CAC) describes the trend of the sector.

\footnotetext{
${ }^{3}$ McKenzie Wark, "Telegram from Nowhere" essay. , Mutations, by Rem Koolhaas, et al. (New York: Actar, 2001) 32.

${ }^{4}$ Wark 35.
} 
Question from Author. "With respect to the aviation industry, how would you characterize the effects of world incidents, infectious disease, and acts of terrorism?"

Daniel Robert Gooch: "A blip is how I would characterize those."

In the fiscal year 2007, worldwide passenger traffic reached the highest volume ever recorded. Increasing $6.9 \%$ over the previous year, total processing is reported at 4.8 billion passengers amongst 76.4 million aircraft movements. ${ }^{6}$

"When we look at growth in the past 10 years, it's been phenomenal. [...] Since 1991, Canada has experienced more than a 50\% growth in domestic passenger traffic and $120 \%$ growth in international traffic" - Daniel Robert Gooch.

TOTAL WOLDWIDE PASSENGERS (billions) Source: Airports Council international

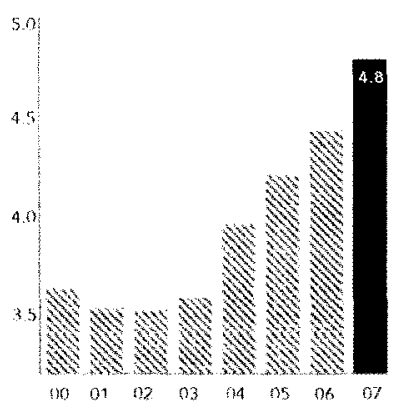

Figure 01

\section{GLOBAL COMMERCIAL AIR TRAFFIC}

Source: Airports Council Interriational

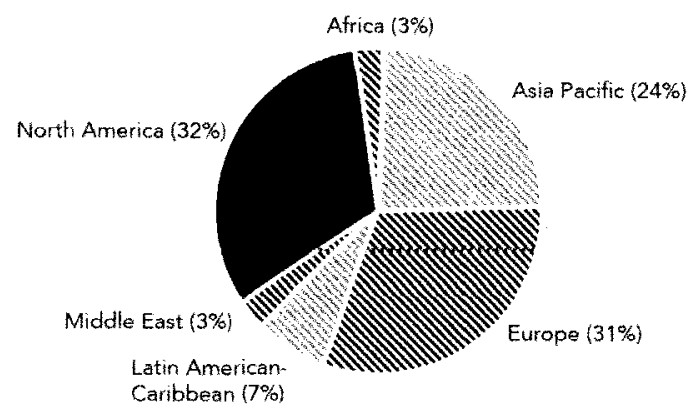

Figure 02.

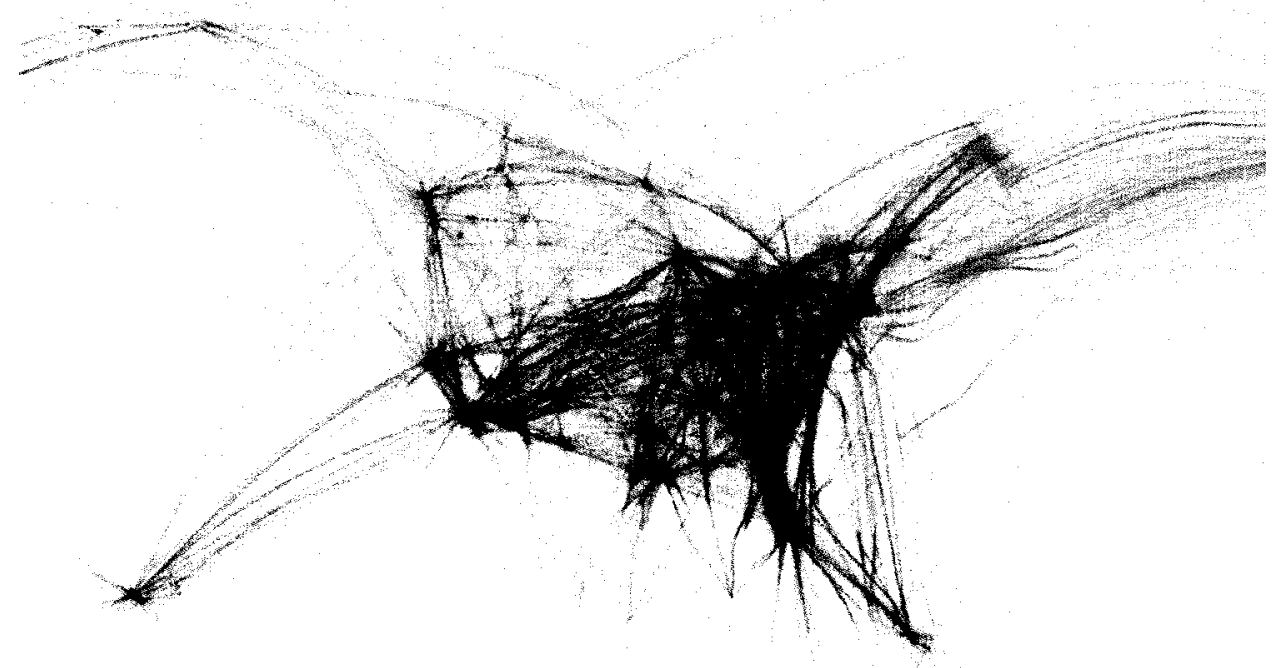

Figure 03. Mapped Commercial Aviation paths over North America

${ }^{5}$ Daniel-Robert Gooch, Director of Communications, Canadian Airport Council, interview by author, $\mathbf{3 1}$ October 2007.

${ }^{6}$ Airports Council International. “Annual Traffic Data." 2007 World Airport Traffic Report. 2007. 28 Oct. 2008 <http://www.airports.org> 
Within this framework, the observations of theorist Giorgio Agamben become strikingly clear. As demonstrated by many multi-cultural nations, Agamben writes, a mass-transit, global world can result in a citizenship whereby residents are neither of blood (of citizen parents) nor soil (born in sovereign territory). In such a case, when the "continuity of man and citizen, nativity and nationality' is broken, fundamental "presuppositions of modern sovereignty" require redefinition. ${ }^{7}$



FIGURE 4: Air Canada Route Map, Enroute Magazine

${ }^{7}$ Giorgio Agamben, Means without End, trans. VBinetti \& C. Casarino. (Minneapolis, University of Minnesota Press, 2000) 131. 
01.1.2 The 'Hyperborder': U.S. \& Mexico

With over one million crossing its threshold daily, the U.S.-Mexico border is the busiest in the world. ${ }^{8}$

TOTAL Border Crossings. U.S / Mexico / 2006 Source: Bureau of Transportation Statiastics

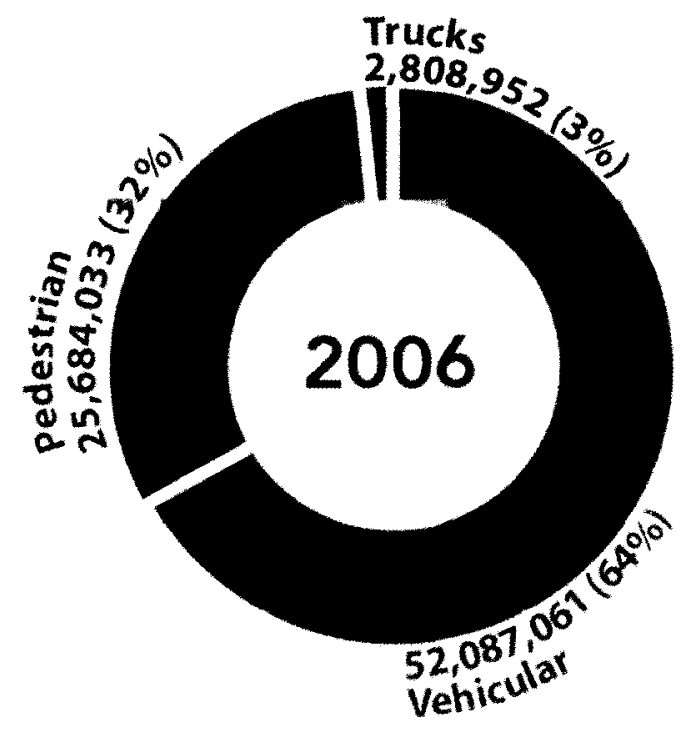

FIGURE 5: Border Crossing and Border Trade

${ }^{8}$ Romero 9. 


\subsubsection{Global Economies, Neo Liberalization and Free trade}

The $19^{\text {th }}$ century philosopher G.W.F. Hegel is perhaps the most notable defender of the liberal state as the ultimate form of human government. ${ }^{9}$ Francis Fukuyama, a political economist and author of End of History and the Last Man argues similarly for the merits of liberal democracies as the endpoint in ideological evolution. The movement toward this governing structure, argues Fukuyama, is largely economically based. ${ }^{10}$ Liberalism, in its economic form, is the recognition of a free economic exchange.

"The growth of liberal democracy, together with its companion, economic liberalism, has been the most remarkable macropolitical phenomenon of the last four hundred years." - Francis Fukuyama

The trend of free-markets has led to neoliberal policies to encourage international trade. Countries seek to open their markets to become more competitive, efficient and integrated within a global economy. "International boundaries are ignored to allow trade, investment and money to flow easily."11

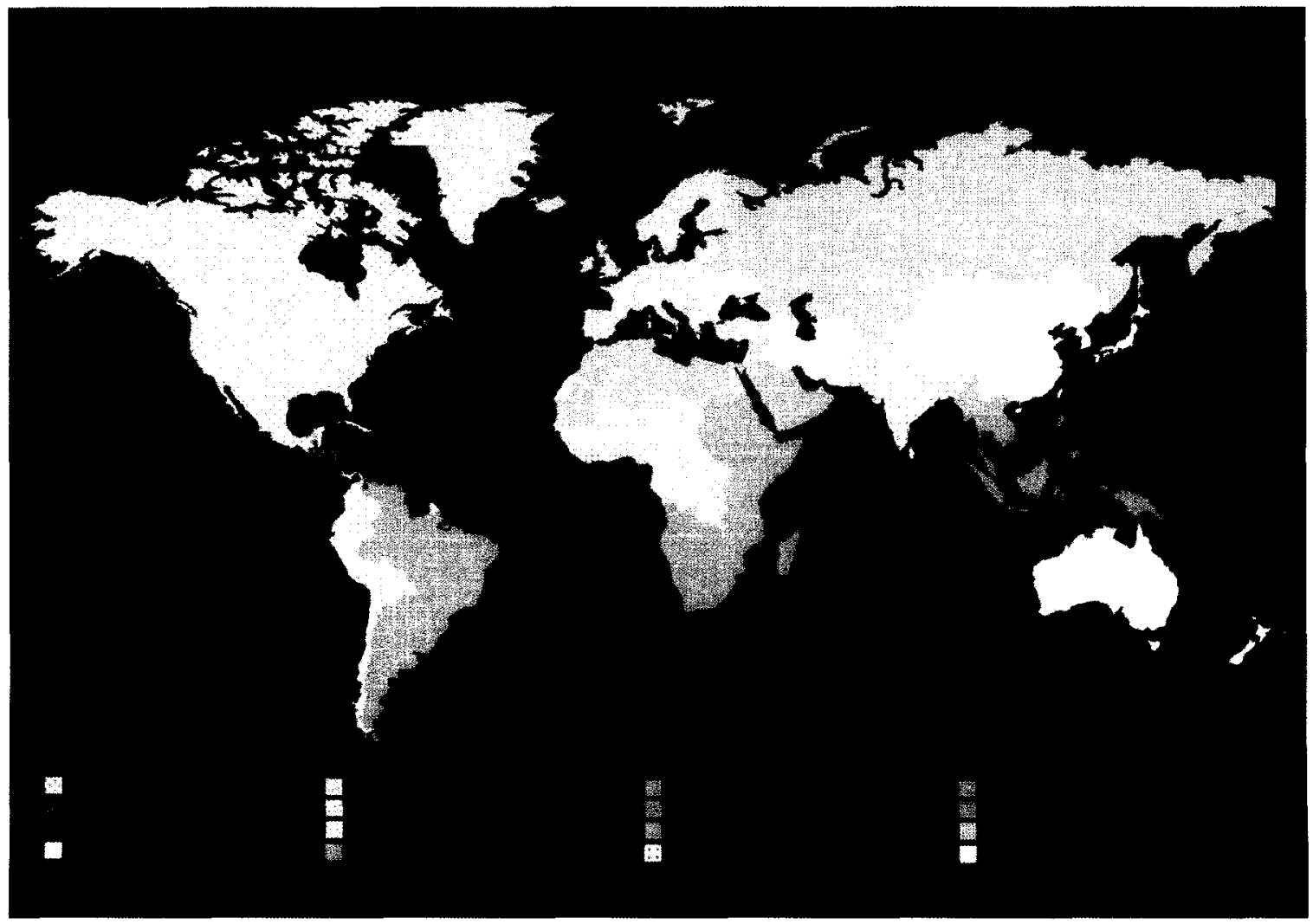

FIGURE 6: The boundaries of economic communities and trade agreements.

\footnotetext{
${ }^{9}$ Francis Fukuyama, The End of History and the Last Man (New York: The Free Press, 1992) xii

${ }^{10}$ Fukuyama 13.

${ }^{11}$ Romero 39.
} 


\section{PART 01.2}

\section{THE FRONTLINE BORDER}

"There will be no individualism without identity checks"

- Marc Augé

"Good fences make good neighbors"

- Robert Frost

While, on one hand, the magnitude of global transit and international trade has blurred the boundary of sovereign territories, the concept of 'territorial integrity' remains a significant principle of international relations. Under the United Nations Charter, 'territorial integrity' is - in part - contingent upon the preservation of existing boundaries. ${ }^{12}$ Particularly in the present climate of heightened threats of terrorism, nation states urgently fortify frontier space in an attempt to control and regulate movement. The inability of any state to meet such requirements presents, in today's environment, a concern for "regional stability and global security"13



The border as a defense measure against external threats, however, is not a new concept. Historically, the enclosure of space defines the extent "within which things can be rationally ordered ${ }^{1314} \mathrm{By}$ extension; enclosure defines a territory of ownership and responsibility of jurisdiction. However, in the face of economic demand, governments must negotiate a new relationship between global transparency and sovereign security.

FIGURE 7: All Nippon Airways (ANA) Security Poster

\footnotetext{
${ }^{12}$ Stuart Elden, "Territorial Integrity and the War on Terror," Environment and Planning A 37. (2005) 2086.

${ }^{13}$ Elden 2097.

${ }^{14}$ Wark 32.
} 




FIGURE 8. New Body Scanners Installed at the 10 busiest U.S. Airports.

\subsubsection{North Korea and South Korea}

Currently, the most fortified border exists between the one-party state of North Korea and the democratic republic of South Korea. ${ }^{15}$ Between these two warring countries lies a $4 \mathrm{~km}$ (2.5 mile) wide demilitarized zone (DMZ). ${ }^{16}$ Established after a cease-fire agreement in 1953, this interstitial space is restricted to military patrol. Once described by former U.S president Bill Clinton as the "scariest place on earth", over two million troops continuously monitor the border on both sides. ${ }^{17}$

\subsubsection{United States and Mexico}

While everyday more than one million people cross the border between Mexico and the United States, the contiguous space of the two nations is one of the most strictly enforced boundaries in the world. As a divide between a leading industrial superpower and a developing nation, illegal activity has existed as a continuing challenge. Under the Department of Homeland Security (DHS), the U.S. Customs and Border Protection (CBP) manage and control all points of entry. Following September 11,2001 the border patrol workforce has grown more than $11 \%{ }^{18} \mathrm{~A}$ proposed 700-mile security fence, as part of the Secure Border Initiative, is expected to integrate anti-vehicles trenches, surveillance cameras, night lighting, and buried motion detectors. ${ }^{19}$

\subsubsection{Canada and The United States: Slowdown, Showdown, or Shutdown}

The destructive and tragic events of September 11, 2001 compelled many to confront fundamental concepts of technological systems and frameworks of global transit. As a collision between two parallel components of globalization - the World Trade Centre as economic engine and the aircraft as engine of international mobility $-9 / 11$ prompted a global reorganization in security policy and border regulation.

\footnotetext{
${ }^{15}$ Romero 26.

${ }^{16}$ Romero 26.

${ }^{17}$ Romero 26.

${ }^{18}$ Romero 76.

${ }^{19}$ Romero 129.
} 
"We still have a long way to go before we can declare America safe and that means doing a better job along our borders"

- John McCain, Republic Candidate, U.S. Presidency Debates,

September 2008

"We are employing better technology, managing risk, and through a layered, defense-in-depth strategy that pushes our border - our zone of security - out beyond our physical borders, so that we know who and what is headed our way before they arrive"

- Robert C. Bonner, Former Commissioner, U.S. Customs and Border Protection (CBP)

Within a Canadian context, the post $9 / 11$ climate instigated several national initiatives. The following is a short list of new agencies, and legislation that are intended to provide improved screening, security, regulation and control along Canadian borders.

\subsubsection{1// CBSA Canadian Border Security Agency}

Created: December 12, 2003

Created through an amalgamation of Canada Customs and Department of Citizenship and Immigration Canada (CIC) and the Canadian Food Inspection Agency (CFIA) "The Agency is responsible for providing integrated border services that support national security and public safety priorities and facilitates the free flow of persons and goods" - Tracie LeBlanc, Communications Officer / Media Relations CBSA

\subsubsection{2 // CATSA The Canadian Air Transport Security Authority}

Created: April 1, 2002

As a crown corporation, the responsibilities of the CATSA include pre-board screening, and management and training of security personnel. ${ }^{20}$ CATSA was created during the December 2001 budget as part of a $\$ 2.2$ billion initiative to address air security in Canada. ${ }^{21}$

\subsubsection{3. // Canadian Anti-terrorism Act (Bill C-36)}

Created: December 18, 2001

As Canada's most significant legislative response following the attacks of September 11, Bill-36 introduced new legal concepts to deter, disable and prosecute individuals or groups engaged in terrorist activities. Following its Royal Assent, the Criminal Code of Canada was revised to include a new component entitled "Terrorism"22

\subsubsection{4 // Canadian Smart Border Agreement}

Created: December 2001

Created to facilitate the flow of 'low risk' travelers, the Smart Border Agreement incorporates information sharing, pre-clearance and technological systems to

\footnotetext{
${ }^{20}$ Kent Roach, September 11: Consequences for Canada (Montreal: McGill-Queen's University Press, 2003) 179.

21 "About Us." Canadian Air Transport Security Authority. 28 Oct. $2008<$ http://www.catsa-acsta.gc.ca>

${ }^{22}$ Roach 21.
} 
expedite screening. ${ }^{23}$ Programs such as the NEXUS Border Initiative include the scanning and documentation of biometric information. ${ }^{24}$

\section{PART 01.3 \\ THE 3RD SPACE}

"In this space, the cradle of accumulation, the place of richness, the subject of history, the centre of historical space, --in other words -- the city, has exploded..."

- Henri Lefebvre

For many people, the recollection of high-school geography class evoke the delightfully precise representations of cartography. Numerous forms of maps, surveys, photographs, and 3-dimensional models communicate the world's diverse physical characteristics. Maps dedicated to the information of human settlement illustrate a striking composition of organized space defined through the inscription of boundaries, and enclosure. The map of world nations, for example, was a colorful rendering with each country diligently circumscribed and filled with a corresponding shade. However, the representation of the borderline as a 2-dimensional spline has been transformed by the activity of international mobility and commerce. As Brian Massumi correctly points out, sovereignty is becoming more about "the patterning of exits and entries across thresholds" than the "impermeabilities of boundaries"25

\section{DEFINING THE 3RD SPACE}

In its classical form, architecture of the threshold was an expression found through portals, gateways, and arches. These conditions represent the delineation between two spaces, a clear architectural divide between 'inside' and 'outside', 'starting point' and 'end point', 'space 1' and 'space 2'. However, in the modern condition, the rise of global mobility has contributed to the manifestation of a 'midpoint' space, a 'space 3'. This territory can be described as the transitory environment between two fixed conditions. In 1909 Arnold Van Gennep, in his text Les Rites de Passage, identified transitory conditions as liminal states. ${ }^{26}$ While originally written in the context of social transition, the concepts of 'liminality' can be applied to movement in time and space.

Uniquely - as it relates to the crossing of boundaries - when the transitory process occurs in the threshold between nation-states - on a ship crossing the Atlantic for instance - the condition implies an existence outside sovereignty. These spaces, that lack identity or national allegiance, are defined by one author as 'non-places'. In his book, Non Places: Introduction to an Anthropology of Supermodernity, Marc Augé defines the non-place as those spaces "which cannot be defined as relational, or historical, or concerned with identity". ${ }^{27}$ The architecture of terminal buildings

\footnotetext{
${ }^{23}$ Roach 141.

${ }^{24}$ Canadian Border Services Agency. Canada's Privacy Statement. 30 October 2008. <http://www.cbsaasfc.gc.ca /prog/nexus/privacy-privee-eng.html>.

${ }^{25}$ Brian Massumi, Parables for the Virtual: Movement, Affect, Sensation (Durham: Duke University Press, 2002) 85.

${ }^{26}$ Arnold Van Gennep, The Rites of Passage, trans. Monika B. Vizedom and Gabrielle L. Caffee. (Chicago: University of Chicago Press, 1960) 21.

${ }^{27}$ Marc Augé, Non-Places; Introduction to an Anthropology of Supermodernity (New York: Verso Publishers, 1995) 78.
} 
best represent the condition of the $3^{\text {rd }}$ space. By their functioning, transportation architecture exists as a transitional space linking a system of points. Within this typology, the airport exists as a distinct model of border territory and the $3^{\text {rd }}$ space.

\subsection{2 // THE 3RD SPACE AND AIRPORT TERRITORY}

Aircrafts, as vessels of international territory, converge and interface with the complex architecture of airport space. Unlike the peripheral border crossings of seaports and highway checkpoints, the airport is a national frontier from within geophysical borders. At these condensed coordinates airports form a contiguous border condition with any nation. As a result, the airport manifests a precise territory of the $3^{\text {rd }}$ space. As one author laments, "The airport is a non-place: its 'topos' is primarily symbolic and transitory; its sociality is solitary and contractual ${ }^{m 28}$

While the $3^{\text {rd }}$ space can be largely understood as metaphorical space of transition, the airport manifests a unique condition which relates to sovereignty and citizenry. Within international terminals there exists an ambiguous territory between the customs and security threshold and aircraft gates. In Canada, foreign travelers do not officially arrive within the country until processed by a Customs Officer. ${ }^{29}$ Therefore, this space - between the time a foreign passenger de-planes and is received by a customs officer - remains a transitory non-place. ${ }^{30}$ As Martha Rosler describes, "The airport of necessity became a limbo, for some purposes neither here nor there." With its detached placelessness it achieves a unique expression. "Certainly not a trans-nation", Rosler writes, "It's a non-nation."31

Spaces dedicated for international operations are secure, sterile environments. ${ }^{32}$ While managed by the private sector, the Canadian government retains the role as safety regulators within all major Canadian International Airports. ${ }^{33}$ Spaces are enforced through Integrated Border Enforcement Teams (IBET) that include members of national and provincial police agencies. From a legal perspective, this territory can be defined as an International Zone under the category of Extraterritoriality. Under this classification, spaces do not prescribe to the jurisdiction of local law but rather observe the governance of international law. ${ }^{34}$ Inhabitants of this space, therefore, exist within a non-place, detached from specific sovereignty and contained within a vectorized environment.

The phenomenon of the $3^{\text {rd }}$ space is perhaps most aptly illustrated in the motion picture movie The Terminal, in which a foreign immigrant - played by Tom Hanks is denied entry to the United States. For the duration of the movie he resides within the boundary of the international transit lounge within which he must find shelter and employment.

${ }^{28}$ Felix Guattari, "Movement: Life in the Air Changes Everything on the Ground ." Aviopolis: A Book About Airports, by Gillian Fuller, Ross Harley (London: Black Dog Publishing LTD., 2004) 44.

${ }^{29}$ Steve Shaw, Vice-president, Marketing and Business Development, Greater Toronto Airport Authority (GTAA), interview by author, 22 October 2007.

${ }^{30}$ Refer to subsequent chapter on airport programmatic layout for clarification. Figure 27/28.

${ }^{31}$ Martha Rosler, In the Place of the Public: Observations of a Frequent Flyer (Ostfildern-Ruit: Cantz Verlag, 1998) 64.

${ }^{32}$ Steve Shaw, interview by author, 22 October 2007.



${ }^{34}$ Romero 33. 
Security Officer: Beyond those doors is American soil. You are not to enter through those doors. America is closed.

Tom Hanks: What will I do here?

Security Office: There is only one thing to do here. Shop. ${ }^{35}$



FIGURE 9. Stills from the Motion Picture, The Terminal

\section{PART 01 CONCLUSION}

The detached placelessness of international airports is not a recent phenomenon. Since the outset of international passenger service, airports have embodied some dimension of the $3^{\text {rd }}$ space. Development in aircraft design brought larger capacities, while the aerial hijackings of the 1970's prompted the compartmentalization of terminal space.$^{36}$ However, there is an evolving context within which the airport must continue to operate. These factors, it is argued, have contributed to a growth in size and defined containment of the $3^{\text {rd }}$ space. It is within these limits where the opportunity for development and architectural exploration reside.

The ease of international mobility and liberalization of trade policy, as discussed in chapter one, has contributed to the growth in airport design and investment. To accommodate incomprehensible passenger capacities, airports now exist as one of the largest building types in the world. The result is an increase in the visible footprint of the $3^{\text {rd }}$ space.

\footnotetext{
${ }^{35}$ The Terminal, dir. Steven Spielberg, perf. Tom Hanks, Catherine Zeta-Jones, Dream Works Pictures, 2004.

${ }^{36}$ Alastair Gordon, Naked Airport: A Cultural History of the Worlds Most Revolutionary Structure (New York: Metropolitan Books, 2004) 231.
} 
To maintain territorial integrity, particularly in light of recent events, the border condition is site of increased restriction, and fortification. Chapter 2 illustrates some measures implemented to control flow and assert jurisdictional enforcement. Airports have bolstered screening processes, tightly encircling international areas. The $3^{\text {rd }}$ space, in this context, reads with clearly defined edges.

What is the appropriate use and expression of this transitory space? Popular strategies of airport design would dictate the development of the $3^{\text {rd }}$ space as a sterile environment for retail and concessions. However, the greater value of this territory lies within its unique characteristic as a liminal space. Victor Turner, cultural anthropologist and author of The Forest of Symbols, expands on Gennep's original concepts of liminality. Turner points out that individuals who exist within liminality shed common signs of status, and rank. The typical social hierarchy, turner describes, is reconstituted to one of commonality. ${ }^{37}$ In other words, the $3^{\text {rd }}$ space is a territory liberated from restriction of geographic, ethnic and political boundaries. As such, this space presents a unique 'place' to embrace a connection between multilateral viewpoints, yet also to consider the common values that connect people globally. Within a considerate framework, the $3^{\text {rd }}$ space can develop as a venue for cooperative exchange.

As Foucault has written, "We are in the epoch of simultaneity: we are in the epoch of juxtaposition, the epoch of near and the far, of the side by side, of the dispersed. We are at the moment, I believe when our experience of the world is less that of a long life developing through time than that of a network that connects points and intersects with its own skein" ${ }^{38}$ Airports are multi-dimensional and multi-national spaces connecting any two points within a system of liminality. As border conditions which mediate aspects of sovereignty, politics, economy and identity, airports represent a confined intensity of cultural simultaneity. International mobility as well as global conflict has resulted in a transitory ' 3 rd space' of significant area and defined limits. Within this site of 'simultaneity' lie opportunities for cultural exchange and architectural exploration.

${ }^{37}$ Victor Turner, The Forest of Symbols: Aspects of Ndembu Ritual (New York: Cornell University Press, 1967) 98.

${ }^{38}$ Michel Foucault, "Of Other Spaces," ms. Diacritics trans. Jay Miskowiec. 16 (1986) 22. 


\section{PART 02}

\section{CASE STUDIES}

The identity, expression and - in the case of the international airport - containment of the $3^{\text {rd }}$ space is shaped by the architecture of transit facilities. The following is an analysis and critical discussion of precedent methods that have contributed to the expression of the $3^{\text {rd }}$ space.

\section{PART 02.1}

\section{KANSAI INTERNATIONAL AIRPORT}

Completed: 1988 (un-built proposal)

Location: Osaka Bay

Architect: Bernard Tschumi Architects

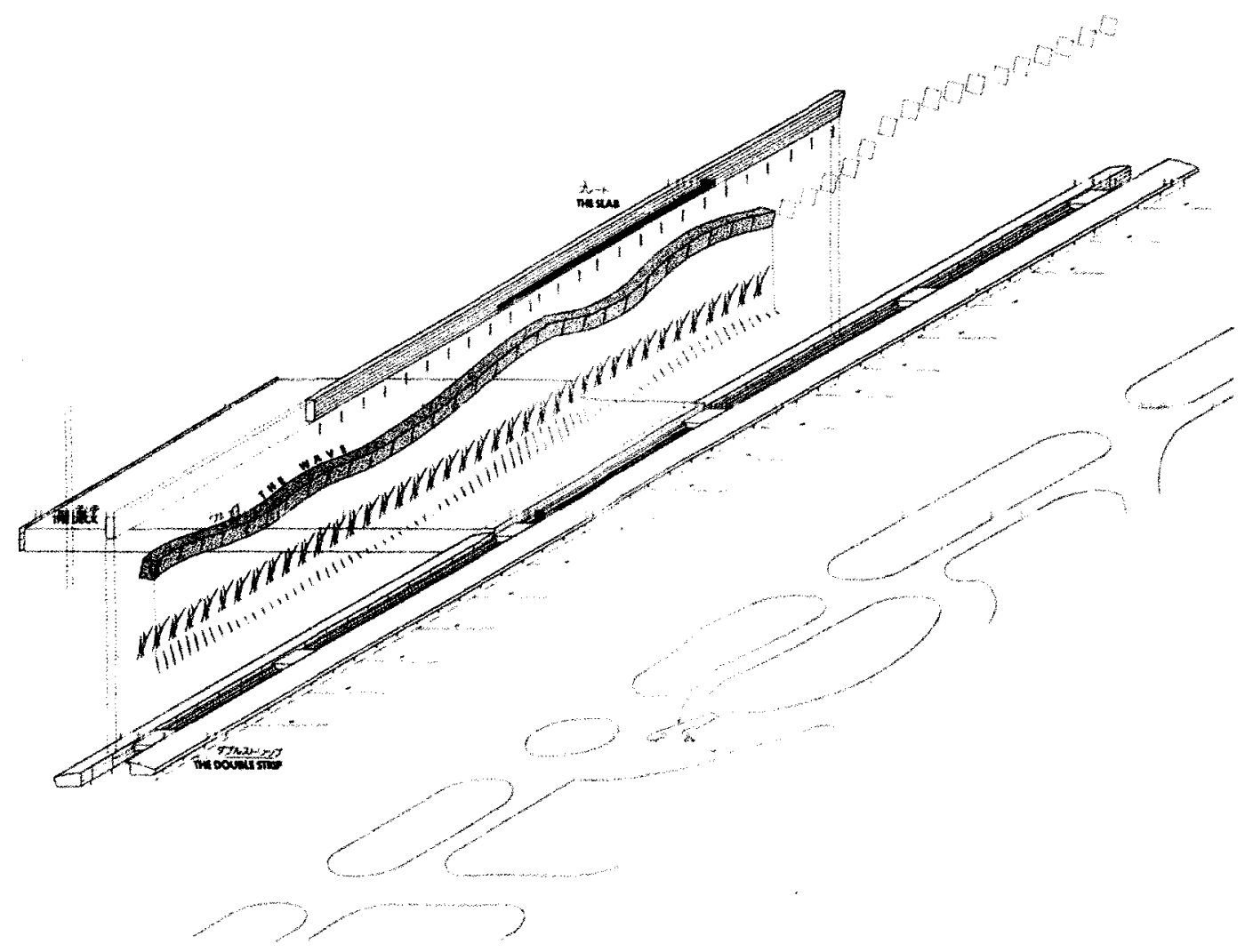

FIGURE 10. Exploded axonometric illustrating building components

It would seem appropriate that the architectural methods which identify the $3^{\text {rd }}$ space as a site for opportunity could be credited, in part, to deconstructivist architects such as Bernard Tschumi. While work of this period can be formally characterized by the fragmentation, and distortion of building elements, Tschumi's work, in particular, questions the relationship between architectural expression and internal function. ${ }^{39}$ Through concepts of 'cross-programming', and techniques of

${ }^{39}$ Bernard Tschumi, Event-Cities: Praxis (Massachusetts: The MIT press, 1994) 13. 
'defamiliarization' Tschumi hopes architecture can exist as a tool for revising social structure and hierarchies. ${ }^{40}$

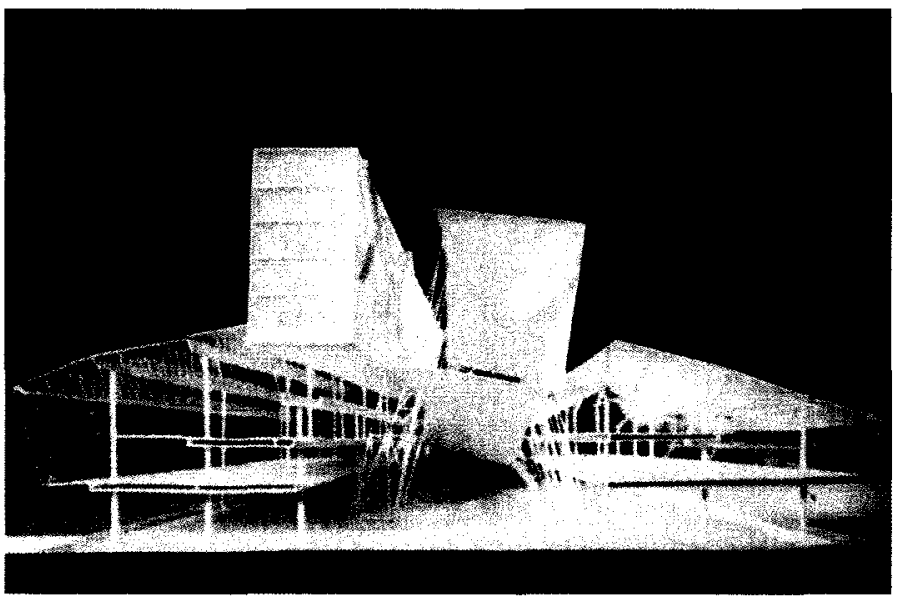

FIGURE 11. Sectional Model

The proposed concept for the Kansai International Airport demonstrates Tschumi's ideas in relation to the territory of the $3^{\text {rd }}$ space. Originally submitted as part of an international competition in 1988, Tschumi provides a detailed account of the project within his publication, Event Cities. ${ }^{41}$ The architectural project conceived the airport terminal as an extension of the metropolis. ${ }^{42}$

"Our ambition is for Kansai International not only to address world travelers but to act as a new urban segment for culture and recreation, superstores and great hotels." Bernard Tschumi, Event-Cities. (105)
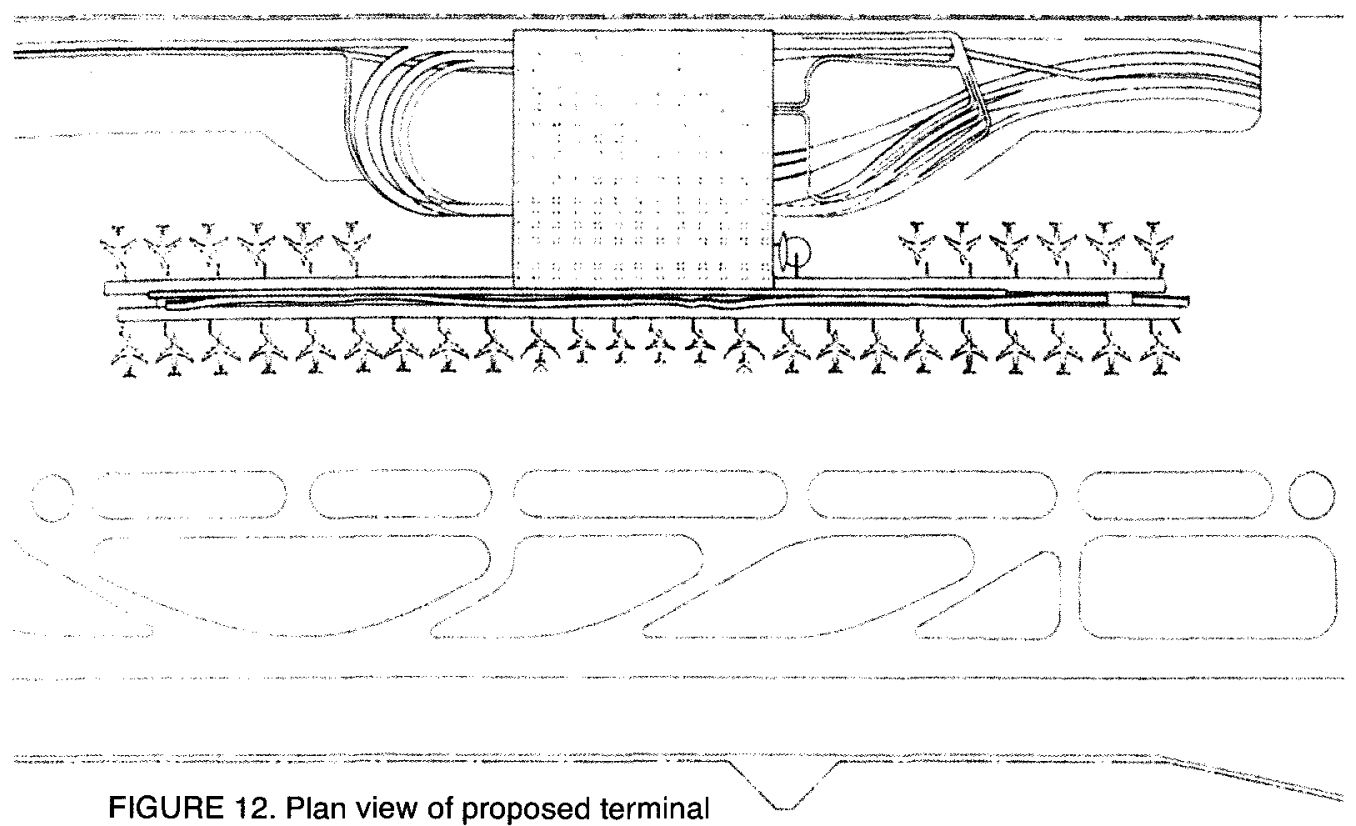

\footnotetext{
40 Tschumi 13.

${ }^{41}$ This international competition was rewarded to Renzo Piano Building Workshop and completed construction in 1994.

${ }^{42}$ Tschumi 105.
} 
The terminal is composed of two fundamental components: 'the linear city' and 'the deck'. (FIGURE 10) The linear city is broken down further within 3 elements. The first, 'the double slab' contains all typical airport functions. The second, 'the wave' integrates a mile long entertainment, cultural, and sports centre. Lastly, ' the slab' is a modular component for hotel suites. The deck exists as an adjacent element and contains adaptive office spaces to support all activities within the linear city.

\section{CRITICAL DISCUSSION}

For Tschumi, the presence of the separate bands is as much about their own internal function as they are about their adjacent relationship. The interstices between bands, describes Tschumi, "questions architectural composition by proposing unclassifiable space". It is argued that within this territory social engagement may occur. ${ }^{43}$ While Tschumi does make a provision for the in-between space of engagement, the architecture lacks a desire to interconnect the various spaces beyond their spatial boundary. Despite Tchumi's objectives of crossprogramming and superimposition, the architectural approach conveys a dominant compartmentalization of program and function. Rendering of respective elements slab, deck, wave, and strip - are conveyed as unitary components. The architectural approach places little emphasis toward the relationship between contiguous elements. As one example the 'slab', as the container of airport function, remains uninterrupted by the added program and hermetically clad within a stainless steel envelope. ${ }^{44}$ Furthermore, the 'deck', as container of mixed office space, is composed as a detached figure perpendicular to the linear city. The engagement between functional elements, sought by Tschumi, appears limited within their detached definition. The architectural composition does not appear to acknowledge other dimension of cross programming which may occur through strategies of visual and material porosity.

Bernard Tschumi's project for the Kansai International Airport recognizes the $3^{\text {rd }}$ space as a site for cultural development, social exchange and architectural exploration. However, the large sweeping gestures compositionally detach building functions and communicate little reference to internal experience or humanistic intonation. The compartmentalization of building elements prevent significant interconnection between programmatic functions leaving airport spaces largely unchanged. As such, the proposed organizational structure, and architectural design lacks the appropriate spatial approach to convincingly represent the $3^{\text {rd }}$ space as a territory of cross programming and defamiliarization.

\footnotetext{
${ }^{43}$ Tschumi 107.

${ }^{44}$ Bernard 107.
} 


\section{PART 02.2}

\section{HAJJ TERMINAL, KING ABDUL AZIZ INTERNATIONAL AIRPORT}

Completed: 1981

Location: Jeddah, Saudi Arabia

Architect: Skidmore, Owings \& Merrill

Project Area: $260,120 \mathrm{~m} 2(2,800,000 \mathrm{ft} 2)$

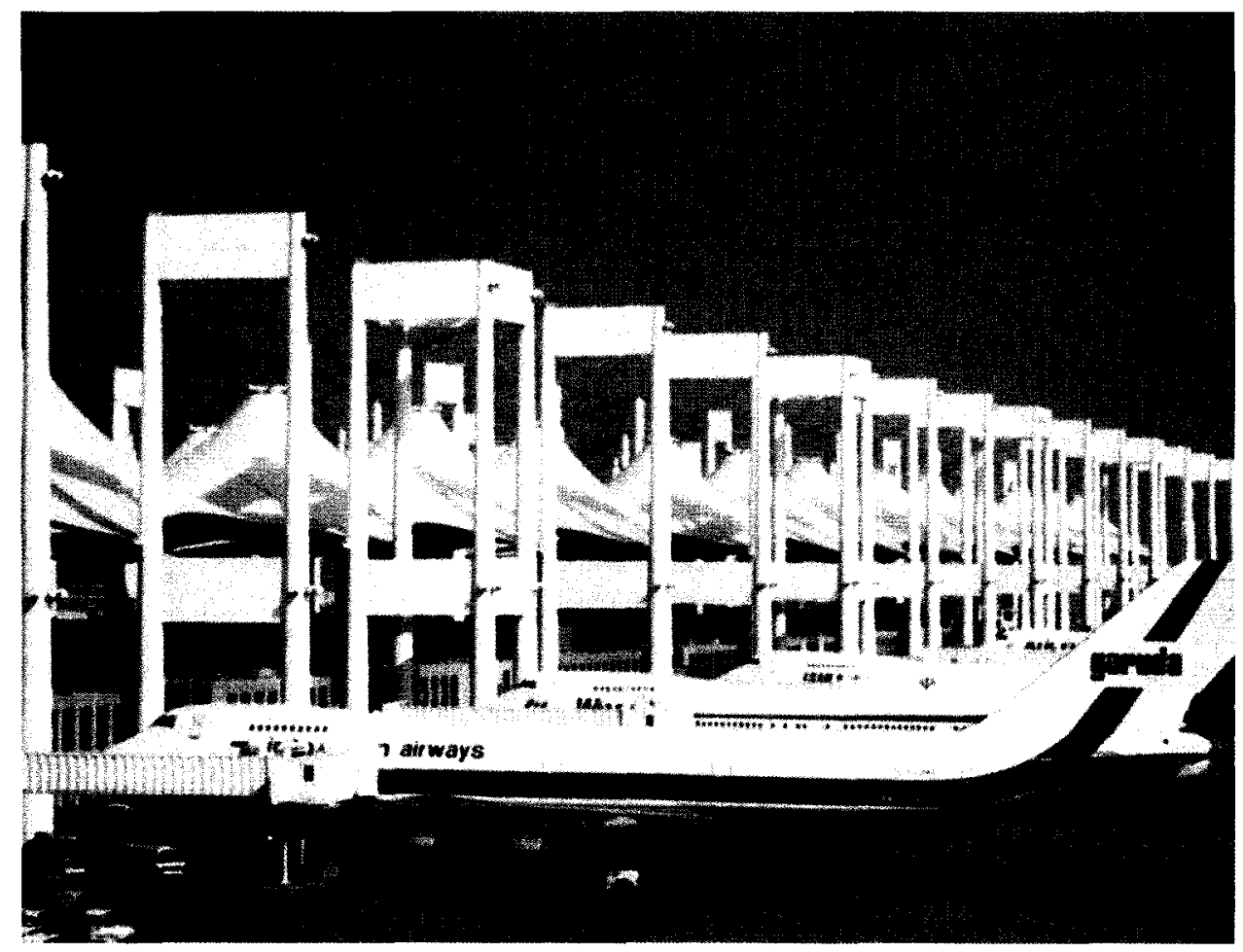

FIGURE 13. Perspective view of modular roof structure.

The Hajj Terminal lies within the greater complex of the King Abdul Aziz International Airport. Constructed in 1981, the terminal is a custom built facility designed to accommodate pilgrims of the Hajj. At the peak seasonal capacity, up to 100,000 worshipers disembark en-route to Mekkah. Due to lengthy wait times (for aircraft and land transport) that range between 24 and 36 hours, the terminal becomes an intermediate lodging for thousands of pilgrims. As a consequence, programmatic areas include cleansing spaces for ritual ablutions, changing rooms, rest areas and cooking facilities for individual meal preparation. ${ }^{45}$

${ }^{45}$ Nicholas Adams, Skidmore Owings \& Merrill. SOM since 1936. (Milan: Electa architecture, 2007) 262. 


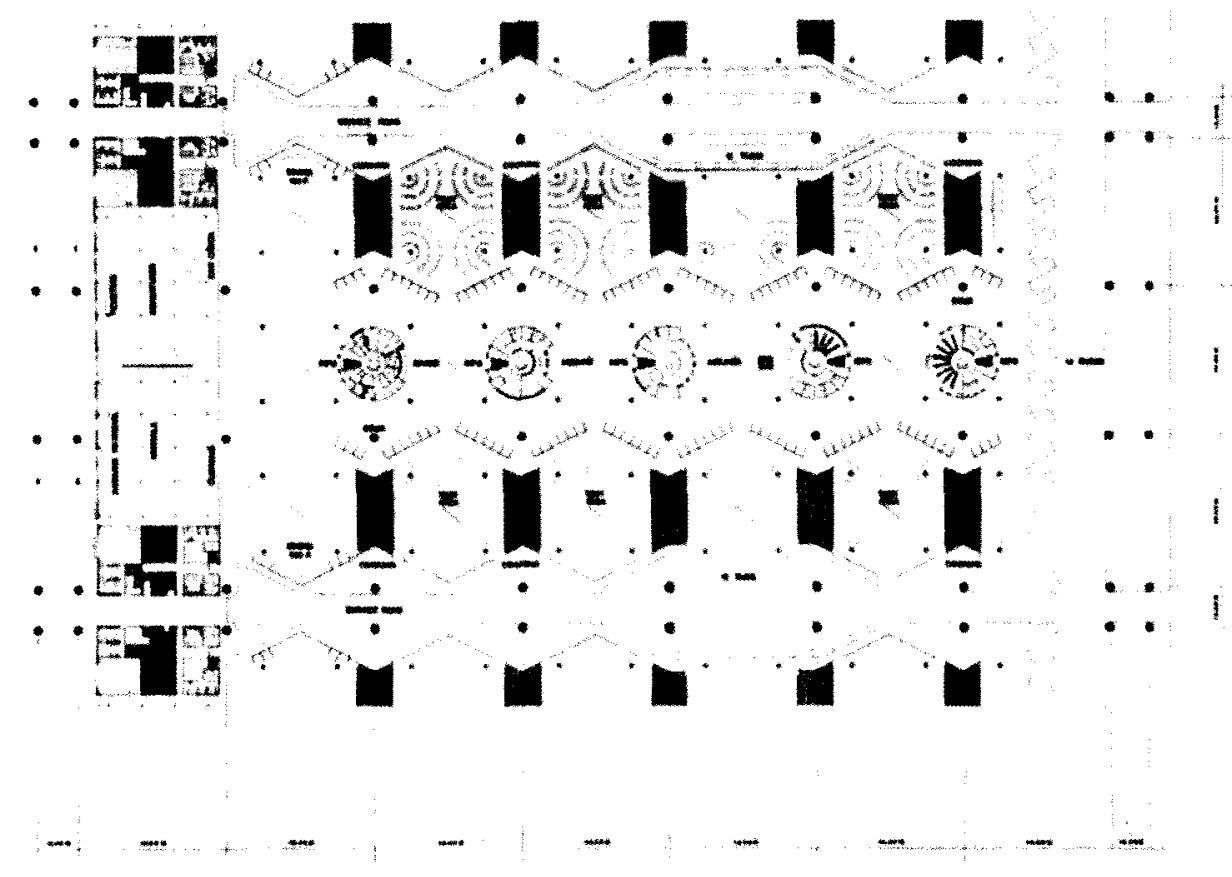

FIGURE 14. Plan of terminal concourse

The architectural expression is dominated by a cable-stayed, tent roof structure. At a peak of 110 feet, the Fiberglas system is a modular design consisting of 150 square foot sections. A total of $\mathbf{2 1 0}$ modules, divided into two fields, cover the 105acre terminal. Uniquely, the construction is not enclosed within an envelope and does not require an air-conditioning system. ${ }^{46}$ Tent modules provide shaded coverage for terminal spaces, roadway entrances, and aircraft gates.
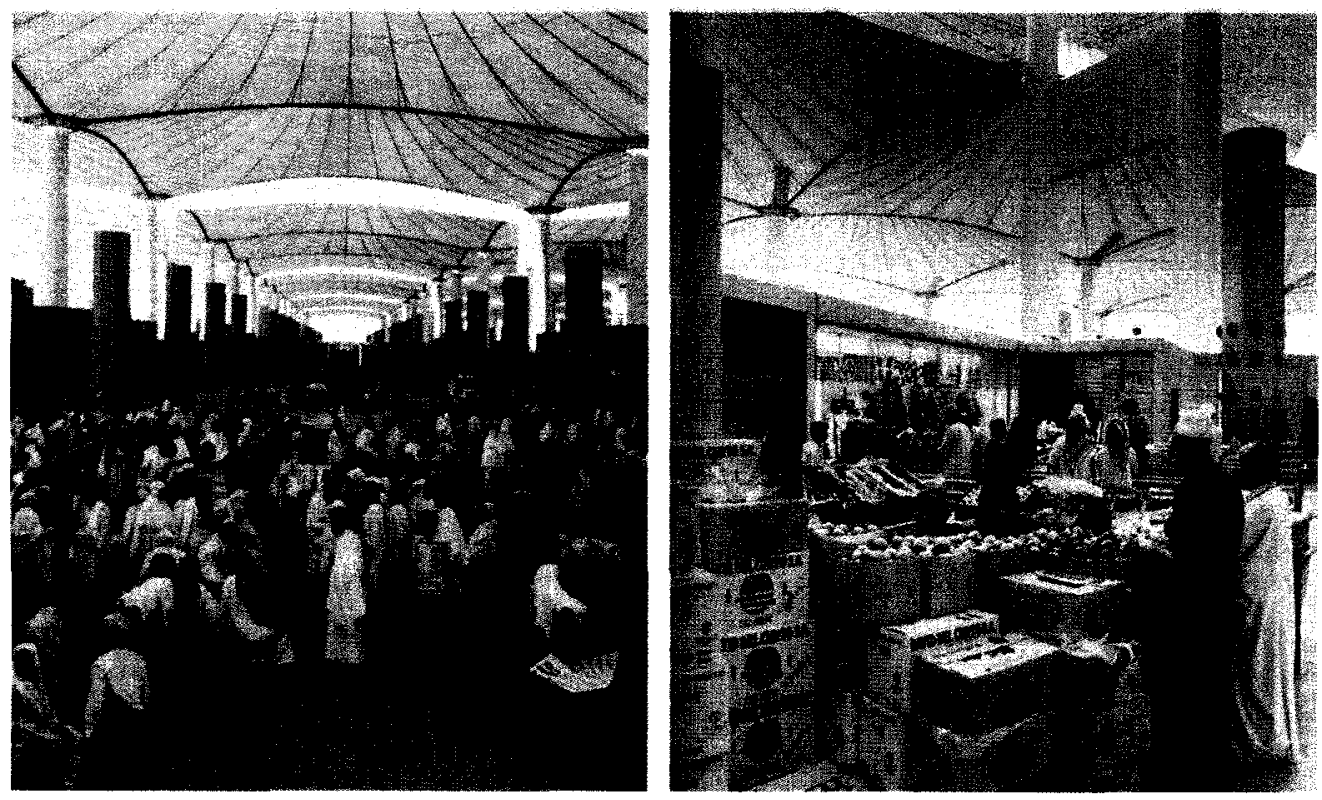

FIGURE 15. Internal view of passenger lounge and retail areas.

${ }^{46}$ Adams 263. 


\section{CRITICAL DICUSSION}

The most striking accomplishment of the Hajj Terminal, in contrast to conventional airport design, is the simplicity of execution. The labyrinthine, multilayered roadway systems, parking structures and impermeable glass facades of typical airports are replaced by a singular datum, the most minimal provision of shelter; a roof. The open-ended, semi-translucent structure provides a breezy shelter underneath which pilgrims establish temporary tenancy. Apart from service blocks and ticket kiosks, passenger areas remain largely uninterrupted and impressionistically unrestricted. Interconnected lounge areas become a collective territory for commingling and communal activities. From the perspective of interior spaces, the terminal areas appear more characteristic of a market space than an international transit facility.

The Hajj Terminal conveys an approach of objectivity. In contrast to conventional terminal design, the architectural solution is reduced to "almost nothing". Through minimal intervention - as argued by modernist creed - spaces may achieve greater adaptability and universality. The Hajj terminal achieves an expression of functional variability through seemingly versatile spaces. However, ambiguity of space, in part, contributes to the popular criticism of liminal territory as a non-place. Marc Augé offers the following definition:

"If a place can be defined as relational, historical, and concerned with identity, then a space which cannot be defined as relational, or historical, or concerned with identity will be a non-place. ${ }^{n 47}$

The $3^{\text {rd }}$ space can exist as a place and as an event space. The Hajj terminal is successful in creating architecture which liberates functions beyond their physical boundary. However, the architecture of the $3^{\text {rd }}$ space must also, in addition to this, be concerned with aspects of identity and the relational challenges of experience. With these criteria, the $3^{\text {rd }}$ space can more effectively convey itself as a defined territory for cultural exchange and social intermingling.

\footnotetext{
${ }^{47}$ Augé 78.
} 
PART 02.3

YOKOHAMA INTERNATIONAL PORT TERMINAL

Completed: 2002

Location: Yokohama, Japan

Architect: Foreign Office Architects

Gross External Floor Area: 438,243 m2

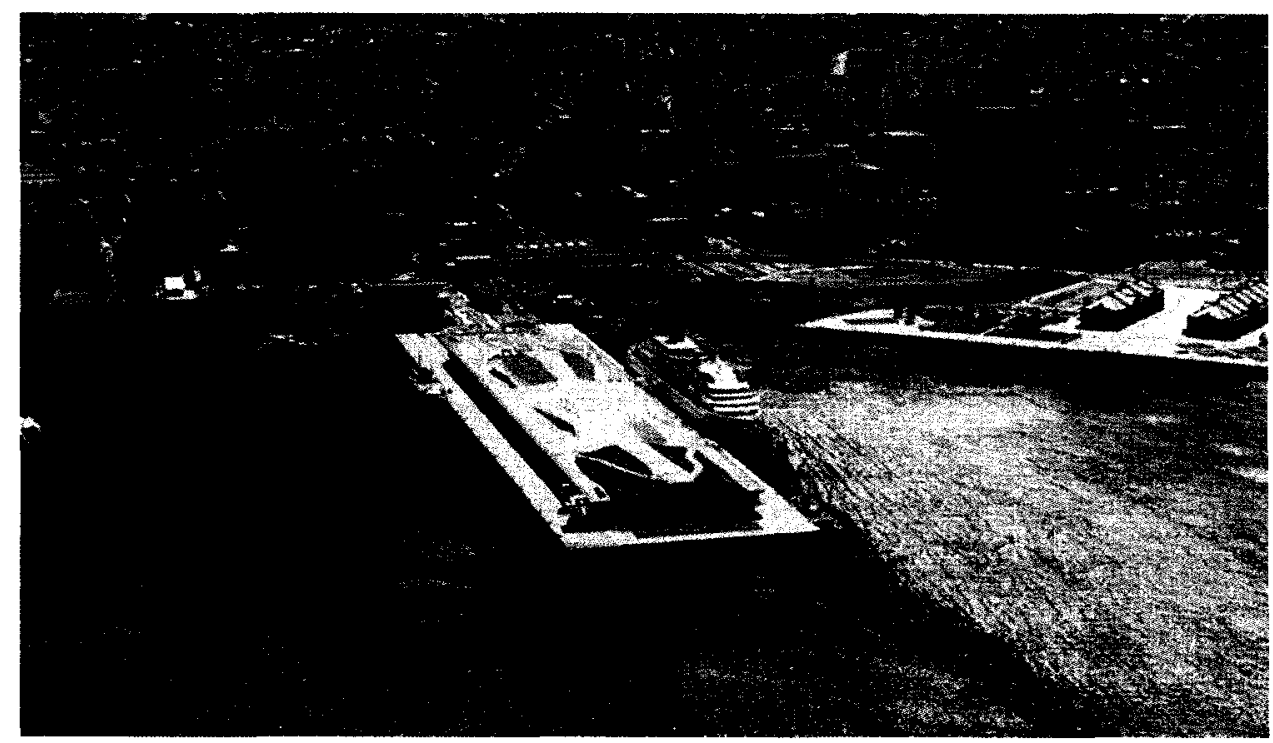

FIGURE 16. Yokohama Port Terminal as added swath of urban infrastructure.

Like the airport, seaport terminals mediate international and sovereign territory through the condition of the $3^{\text {rd }}$ space. The Yokohama International Port Terminal is a public transit facility for large scale cruise ships. Able to accommodate up to 4 vessels at one time, the facility contains flexible processing areas for immigration and passport control. However, Foreign Office Architects - selected in the 1995 international competition - conceived additional programme areas to facilitate greater exchange between city and harbor. Public spaces include multi-functional rooms, a continuous roof plaza, and retail areas. 


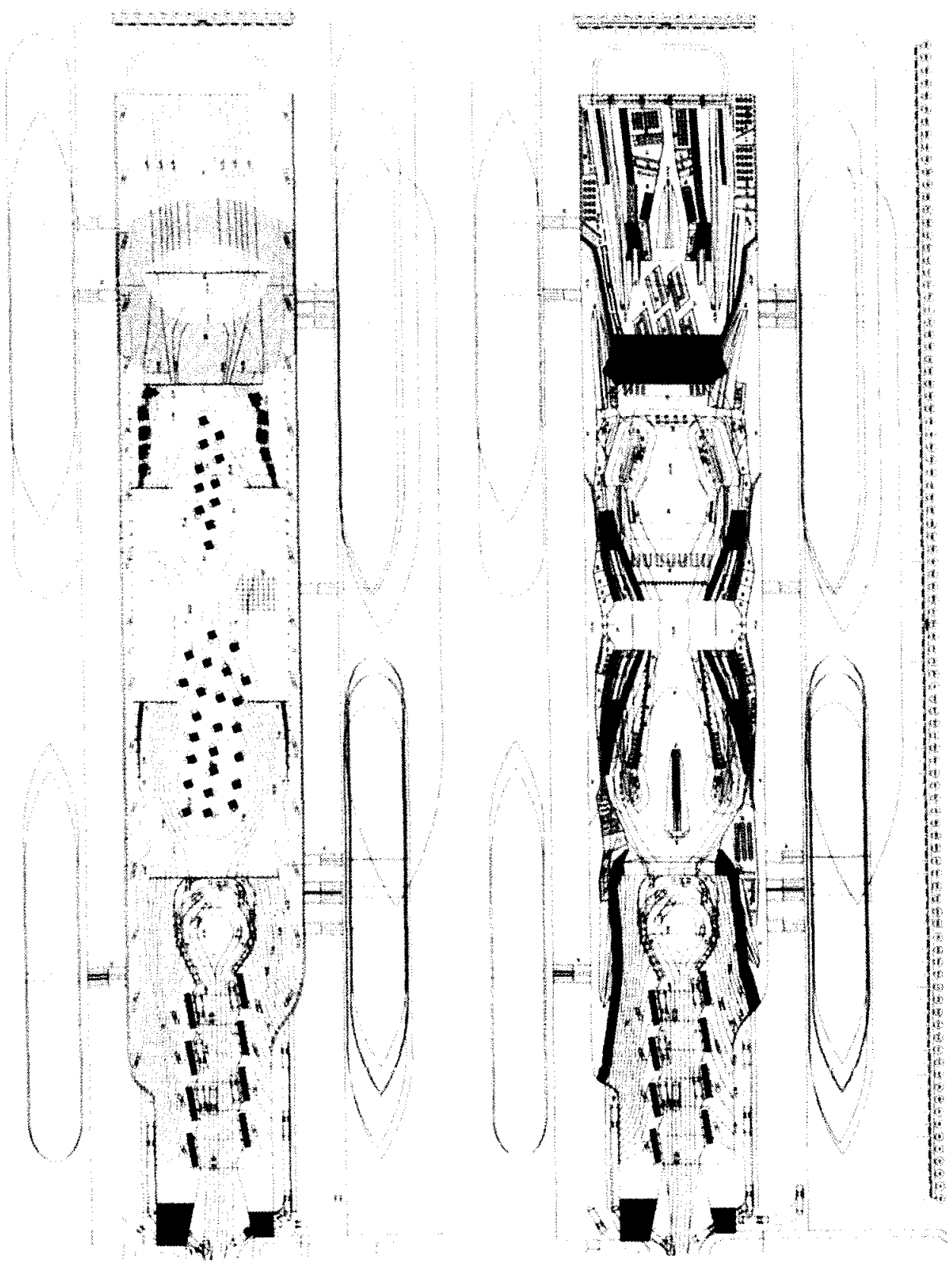

FIGURE 17. Plan views illustrating passenger areas

Conceived through patterns of circulation, the design challenges functional containment through warped surfaces, distorted spaces and wrapped planes. ${ }^{48}$ The aspiration of the architects is to manifest the pier as a field of movement rather than a gate or space of limits. ${ }^{49}$ This approach to 'de-territorialization' is addressed in two ways. The first was to devise a form of public space that enveloped the entire building. The second was based on a function of structure that would not impose "instruction for occupation". The aim, as described by the architects, was to move "imperceptibly between spaces" transforming states into a gradation of intensity

${ }^{48}$ Foreign Office Architects, The Yokohama Project (Barcelona: Actar, 2002) 11.

${ }^{49}$ Foreign Office Architects, "The Yokohama International Port Terminal," El Croquis 115/116[1]. $2003: 42$. 
"countering the effects of rigid segmentation - especially those dedicated to maintaining borders."



FIGURE 18. Exterior view. Main entry.

\section{CRITICAL DISCUSSION}

The Yokohama terminal demonstrates a rigorous mediation between passenger flow and public space. As a swath of terrain grafted onto the urban edge, the building extends the infrastructure of the city. Spatial metamorphosis and functional diversity encourage a multiplicity of events. As a result, its physical presence resonates within the city as a landmark site for public use. Within the architecture, the exaggeration of threshold conditions, continuity of materials and transparency of spaces bleed functions from a prescribed containment. Movement between interior and exterior space is experienced seamlessly through a slippage of planes. In the context of an international transit facility, these spatial characteristics are particularly meritorious. The $3^{\text {rd }}$ space thus conveys itself as a complex networked system intersecting city, harbor and sea.

Through the Yokohama project, Foreign Office Architects acknowledge the latent value of the liminal territory. The integration of cultural programming as well as the 'de-territorialized' formal expression conveys the $3^{\text {rd }}$ space as an inclusive territory of interaction. However, the architecture presents several challenges with respect to legibility and utilization. While the design aims to dismantle rigid operational frameworks of transit facilities, the ultimate fluidity of space and form may, arguably, detract from its ultimate success. Unlike the architect's description, the uninterrupted surfaces convey uniformity and constancy rather than "degrees of intensity". Public areas are deliberately stripped of furnishings to maximize their ambiguity. Interior and exterior spaces provide minimal seating while - perhaps ironically - limited grass areas remain off limits. ${ }^{51}$ In this manner, the port terminal fulfills a characteristic of built form identified by Gilles Deleuze and Félix Guattarr, in Milles Plateaus as 'smooth space'. Together with its counterpoint, 'striated space', these qualitative terms form the fundamental components of spatial experience. As illustrated by Deleuze and Guattarr, smooth space represents the vector of the nomad, a transient space. In contrast, striated space is the territory of the

\footnotetext{
${ }^{50}$ Foreign Office Architects, "The Yokohama International Port Terminal,": 42.

${ }^{51}$ This observation was made during a visit by the author, February 20, 2008.
} 
sedentary, a node or destination. ${ }^{52}$ The Yokohama Port Terminal is a construction dominated by perpetual movement of 'smooth space'. If the architecture of the $3^{\text {rd }}$ space is to emerge as a territory for cultural development and of unique identity, built form must holistically integrate and balance forms of both smooth and striated space.

\section{PART 03 PROPOSED ARCHITECTURE}

\section{PART 03.1 \\ PROJECT PROPOSAL}

\subsection{1 // PROPOSED PROJECT}

The architectural project proposes a mixed-use facility within the international component of a 3-sector airport terminal. The terminal component accommodates all sectors of passenger service, which include Domestic, Regional and International operations. Mixed-use facilities include hotel accommodates, leisure amenities, and conference facilities to support performances, conventions, cultural shows and gallery exhibitions.

\subsection{2 // PROJECT INTENT}

The proposed project is an investigation into the phenomenal experience of interstitial space. Border territory, as the interstice between boundaries of nation-state, is the non-nation, extraterritorial domain of international space. The international component of airport architecture defines the extent of this terrain. The intent of the research can be described relative to two fundamental questions. The first asks: Once this space has been identified, the architecture within it should fulfill what function? The second question, although interconnected to the first, asks: What is the appropriate architectural expression within this landscape?

The particularities of these questions are addressed concurrently within the following sections relating to programmatic concept and architectural design approach. The general objective lies in the derivation of an international space architecture that is defined through the multiplicities of cultural exchange, commingling and interconnection.

\subsection{3 / PROJECT CONTEXT AND SCOPE}

The proposed project is presented as an added component to the airport development program (ADP) originally drafted by the Greater Toronto Airport Authority (GTAA) in 2002. The following investigation is primarily focused on the design of a mixed-use public facility and new international passenger terminal. Roadside development, land-use and master planning principles are also discussed.

${ }^{52}$ Gilles Deleuze, and Félix Guattarr, A Thousand Plateaus trans. Brian Massumi. (Minneapolis: University of Minnesota Press, 1987) 474. 


\section{PART 03.2}

\section{SITE AND CONTEXT}

\subsubsection{1 // OVERVIEW}

The proposed terminal development is situated at the existing Lester B. Pearson International Airport. Located 27 miles west of downtown Toronto, the 1,867 -hectare $(4,613$ acre) site is the location of Canada's largest and busiest airport. Handling over 31 million passengers annually, the facility is ranked globally as $29^{\text {th }}$ among the world's busiest airports. ${ }^{53}$ As a member of the National Airport System (NAS), Pearson is owned by Transport Canada and leased to a local authority for management and operation. ${ }^{54}$

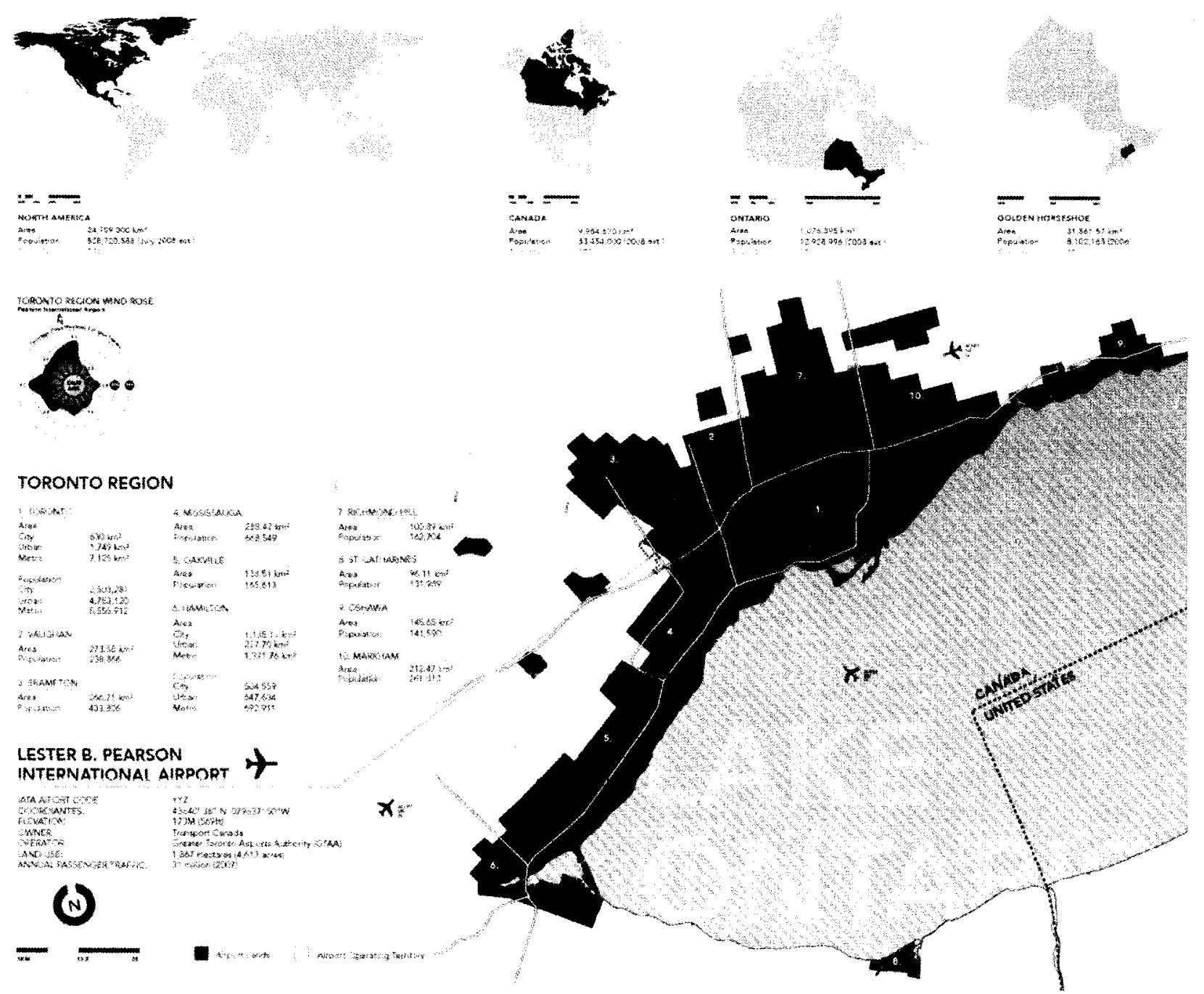

FIGURE 19. Regional Context

${ }^{53}$ Airports Council International. "Passenger Traffic 2005." 30 Oct. 2008. <http://www.airports.org>

${ }^{54}$ Daniel-Robert Gooch, Canadian Airport Council, interview by author, 31 October 2007. 
LOCATION: Lester B. Pearson International Airport

IATA AIPORT CODE: YYZ

COORDIANTES: $43040^{\prime} 38^{\prime \prime} \mathrm{N}$ 079037' 50"W

ELEVATION: $173 \mathrm{M}$ (569ft)

OWNER: Transport Canada

OPERATOR: Greater Toronto Airports Authority (GTAA)

LAND USE: 1,867 Hectares (4,613 acres)

ANNUAL PASSENGER TRAFFIC: 31 million (2007)

$30 \%$ of Canada's Air Passenger traffic

$47 \%$ of Canada's air cargo (Source: GTAA master plan, 1.6 )

\subsection{2 // HISTORICAL BRIEF}

The original 425 Hectare $(1,050$ Acre) site was purchased in 1937 by the Federal Government shortly after the creation of the Department of Transport. ${ }^{55}$ Prior to this period, civil and military aircrafts operated from several aerodromes throughout the region. A dedicated facility promised safe operations for aircraft throughout the year. Opening in 1939, the original terminal operated from a converted farmhouse. Toronto Municipal Airport, as it was originally known, began public operations in 1938 with regular scheduled service between Buffalo, NY and Toronto. ${ }^{56}$ The first purpose-built terminal was constructed in 1939 and was of identical design to the present-day Toronto Island Airport Terminal. Subsequent construction of a single-storey brick terminal in 1954 helped mitigate growing traffic demands during the post-war period. The inception of the jet-age instigated the expansion of runway systems as well as construction of a modern 23-gate aeroquay facility designed by John C. Parkin. Despite a progressive design, growing trans-oceanic services and developing requirements for passenger aircrafts quickly outmoded Terminal $1 .{ }^{57}$ To supplement operations Terminal 2, completed in 1972, accommodated an additional 6 million passengers annually. ${ }^{58}$
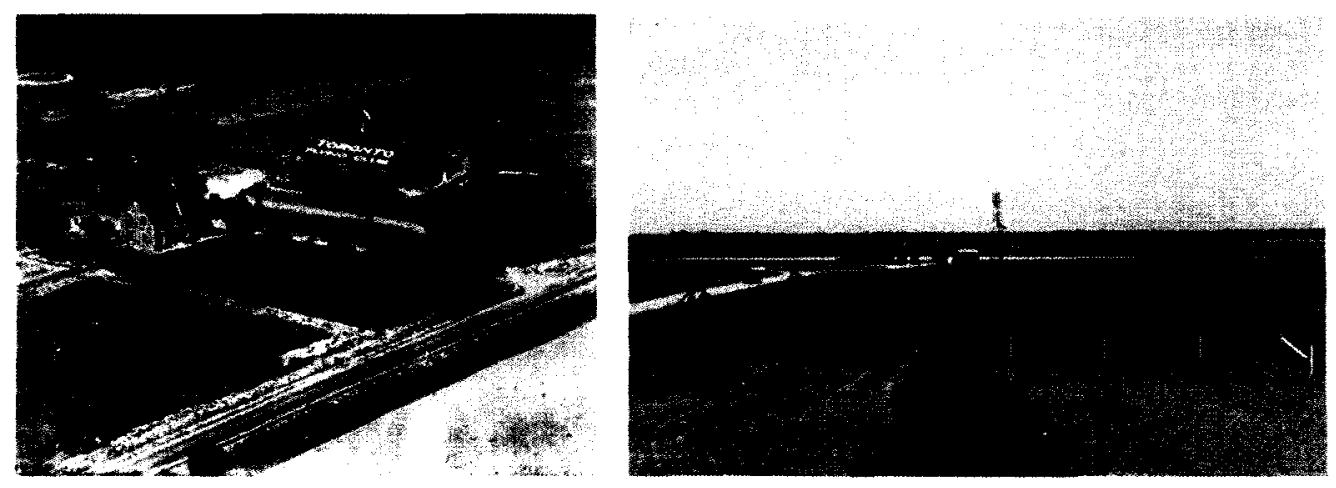

FIGURE 20. Original converted Farmhouse, circa 1930. FIGURE 21. Malton Airport, 1939.

\footnotetext{
${ }^{55}$ Greater Toronto Airports Authority (GTAA), Celebrating Success: GTAA 10 year anniversary (Toronto: 2006) 4.

${ }^{56}$ Greater Toronto Airports Authority, Celebrating Success 6.

${ }^{57}$ Followings the construction of Terminal 1, a NASA committee chaired by Carl Sagan chose a photograph of the terminal as one of the 115 images for the Voyager spacecraft golden record. Launched into space in 1977, images selected were intended to represent human civilization.

${ }^{58}$ Greater Toronto Airports Authority (GTAA), "Introduction," Taking Flight: The Airport Master Plan 20082030 (Toronto: Grafikom, 2007) 20.
} 




FIGURE 22. Malton Airport, circa 1950.



FIGURE 23. Pearson International Airport, Terminal 1, 1965

The 1980's was a period of liberalization. While the federal government initiated movement toward the privatized operation of Canadian airports, the deregulation of domestic air travel prompted further expansion of the airport system. Terminal 3, completed in 1991, was the first airport terminal in the world to be designed, built and operated by a private enterprise on federal property. ${ }^{59}$ A privatized framework, as argued by then Transport Minister John Crosbie, would provide greater community accountability, management efficiency and economic opportunity. ${ }^{60}$

In 1994, Transport Canada officially recognized the Greater Toronto Airport Authority (GTAA) as the not-for-profit operating agency at Pearson International. Under a 60-year lease from Transport Canada, GTAA is responsible for the operation, management and maintenance of the airport lands. ${ }^{61}$ Immediately following its constitution, the GTAA embark to develop the Pearson airport site. As per the recommendations of a Transport Canada planning report, the GTAA initiate expansion plans to address forecasted aviation demands. ${ }^{62}$ The $\$ 4.4$ billion undertaking, known as the Airport Development Program (ADP), included refurbishment, replacement and expansion of facilities. ${ }^{63}$ From 1994 to present day, Pearson has undergone a series of new constructions that include a:

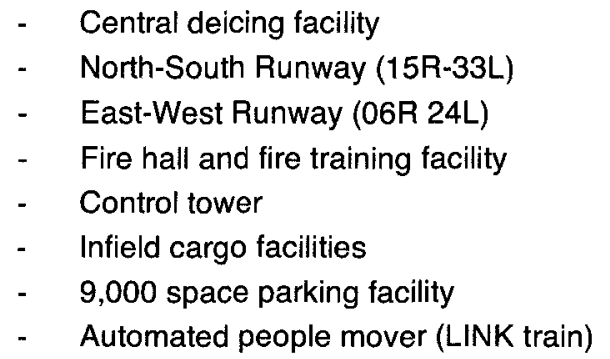

Most substantial among these new projects is the construction of a unified passenger terminal designed by an international consortium consisting of Moshe Safdie and Associates, Skidmore, Owings and Merrill LLP (SOM), and Adamson Associates Architects. Conceived as part of a phased planning development, the new structure replaces both existing terminals

\footnotetext{
${ }^{59}$ GTAA, Celebrating Success 12.

${ }^{60}$ GTAA, Celebrating Success 18.

${ }^{61}$ GTAA, "Introduction," Taking Flight 20.

${ }^{62}$ GTAA, "Introduction," Taking Flight 3.

${ }^{63}$ Airports Authority, "Introduction," Taking Flight 20.
} 
1 and 2. In its current phase, the new terminal 1 has a passenger capacity of 21 million annually. ${ }^{64}$

These development measures have enabled the growth of annual traffic to 31 million passengers. The GTAA future planning objectives are to maximize development potential. With forecasted demands of 50 million passengers by 2020 , the GTAA planning goals include further terminal and airside expansions. ${ }^{65}$

TERMINALS AT PEARSON

1939

$13 \mathrm{M} \times 12 \mathrm{M}$ two level facility (DEMOLISHED)

Architect: unknown

1954

(expansion 1959) (DEMOLISHED)

Single Storey Brick structure

400,000 annual capacity

Architect: unknown

1964

Terminal 1 (DEMOLISHED)

23 gate

3.5 million annual capacity

6.5 million, (1981 expansion)

56,180 square meters

Architect: John C. Parkin

1972

Terminal 2 (DEMOLISHED)

31 gate

6 million annual capacity

9 million (1977 expansion)

84,978 sq. m.

Architect: John C. Parkin

1991

Terminal 3

24 gate

10 million annual capacity

119,060 sq. m.

Scott Associate Architects Incorporated

2004

New Terminal 1

Current (2007)

73 gates ( 24 commuter +49 bridged)

21 million annual capacity

346,000 sq. $m(4,000,000$ sqft $)$

${ }^{64}$ GTAA "Passenger Terminals," Taking Flight 1.

${ }^{65}$ GTAA "Airport Development Program," Taking Flight 6. 
Architects: Moshe Safdie and Associates / Skidmore, Owings and Merrill LLP (SOM) //

Adamson Associates Architects

Master Plan (2020) :

189 gates ( 32 commuter +157 bridged)

54 million annual capacity
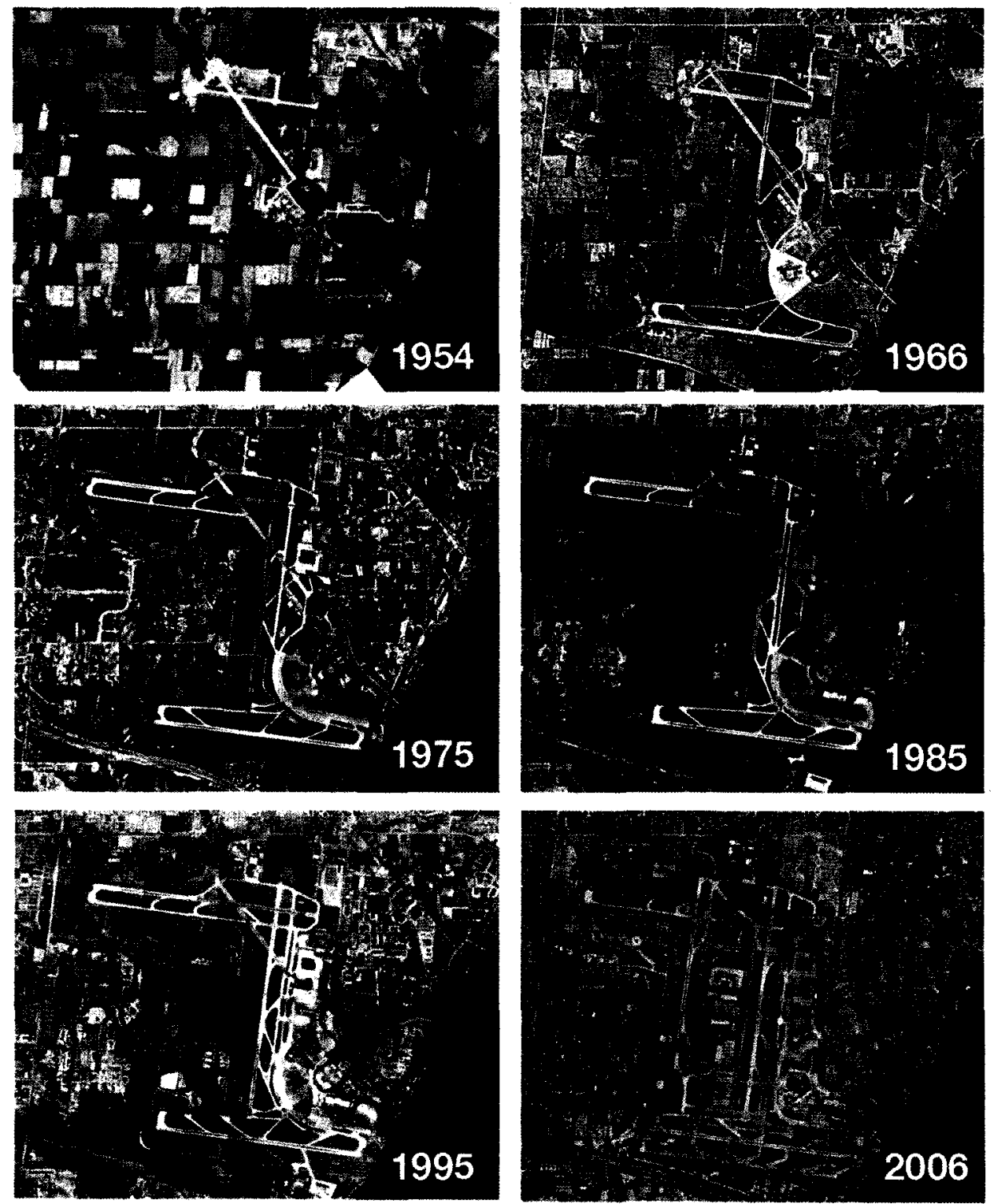

FIGURE 24. Aerial photography illustrating development of the airport lands.

\subsection{3 // SITE CONTEXT}

While Pearson International is largely known as Toronto's airport, the physical territory of the airport does not exist within the boundary of the Greater Toronto Area (GTA). The site lies just beyond the westerly extent of the GTA, in the north-east quadrant of Mississauga.

The boundary of Pearson International is defined by several major highways and local roads. Highway 401 to the south and Highway 427 to the east provide access to downtown Toronto and various communities of south-central Ontario. Airport Road defines the north-east 
boundary and, in addition to the highway infrastructure, provides civilian access to all terminal systems. Derry Road and Dixie Road define the north-west and south-west limits of the airport lands.

In addition to Mississauga and Toronto, Pearson is bordered by the regions of Peel, York and Halton. The built form adjacent to the airport has developed rapidly over the last decade. Surrounding density has reached such a level whereby the boundary of the vast airside system is made clearly visible in contrast to built form. Adjacent land use is largely limited to employment areas. While the airport lands occupy 1,867 hectares ( 4,613 acres), the airport operating territory, - the jurisdiction of arriving and departing aircraft - extends nearly three times that amount at approximately 5,500 hectares. $(14,000 \text { acres })^{66}$ (figure 18) Aircraft movements within these areas have vastly affected built form. Noise infiltration within neighboring communities has instigated the development of predominantly commercial and industrial areas.



FIGURE 25. Site Context.

${ }^{66}$ GTAA "Noise Management," Taking Flight 10. 


\subsection{4 // EXISTING SITE CONDITIONS}

As a strategy to clearly comprehend the vast territory and complex facilities of the airport land, the GTAA master plan defines several sub territories within its 1,867-hectare site. They include Airport East, Airport Infield, Airport South, Airport North, Airport East Access, Airport Airside, and Other Airport Lands. ${ }^{67}$ (Figure 26)

\section{AIRPORT EAST}

259.2-hectares (640 acres)

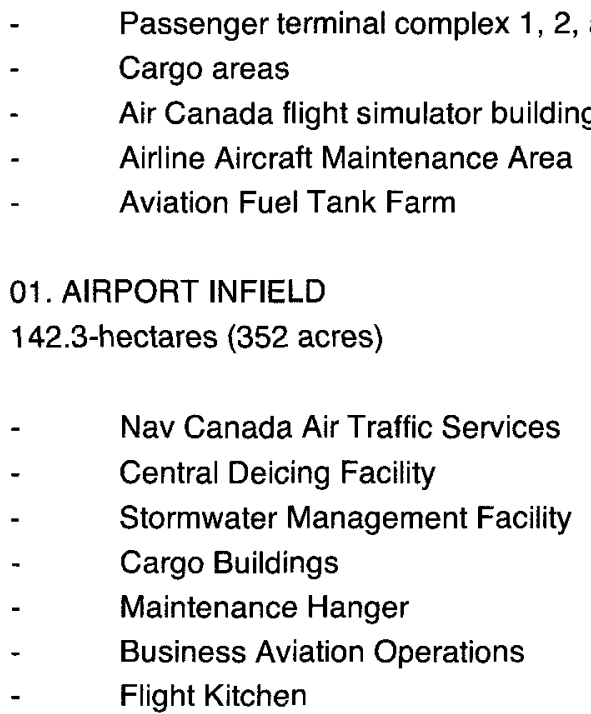

07. AIRPORT SOUTH

55.3-hectares (136 acres)



\footnotetext{
${ }^{67}$ GTAA "Introduction," Taking Flight 11.
} 
- $\quad$ Employee Parking

- Central Utilities Plants

- $\quad$ Reduced Rate Parking

- All inbound and outbound Highway infrastructure

02. AIRPORT AIRSIDE

1,168-hectares $(2,886$ acres $)$

- Runways

- Taxiways

- Navigational aids

- $\quad$ Airside roadways

- $\quad$ Fire and Emergency Training Facility

06. OTHER AIRPORT LANDS

11.3-hectares (28 acres)

- $\quad$ storm water management

- $\quad$ parking 




FIGURE 26. Land areas.

\section{PART 03.3}

\section{DESIGN}

\subsection{1 // PROGRAMMATIC CONCEPT // ORGANIZING HYPOTHESES}

The proposed construction serves two functions. A mixed-use facility provides meeting and exhibition space for up to 5,000 users. It is situated within the international territory of an airport terminal. These functions, while independent in operation, are integrated within a single development.

The terminal component prescribes to typical functions common to 3-sector airports. While some of these elements are reinterpreted, their sequence of experience remains unchanged. For outbound passengers, the departing sequence can be described in 4 stages: curbside $/$ public transit, check-in, security clearance and boarding. For inbound passengers, arrival consists of deplaning, customs/security clearance, baggage claim, and curbside/ public transit. 




FIGURE 27. DIAGRAM: CONVENTIONAL AIRPORT LAYOUT

The security checkpoint for inbound and outbound passengers delineates private and public space. Gillian Fuller, in a critical discussion of airports, defines this distinction as sterile and non-sterile space, respectively. ${ }^{68}$ This threshold is also the transition to the place of the $3^{\text {rd }}$ space. The proposed mixed-use facility resides within the environment of this non-nation territory.

"It's a processing space. It's a secure space. And it can't be too Canada." -Steve Shaw, Vice President, Marketing and Business Development, Greater Toronto Airports Authority (GTAA)

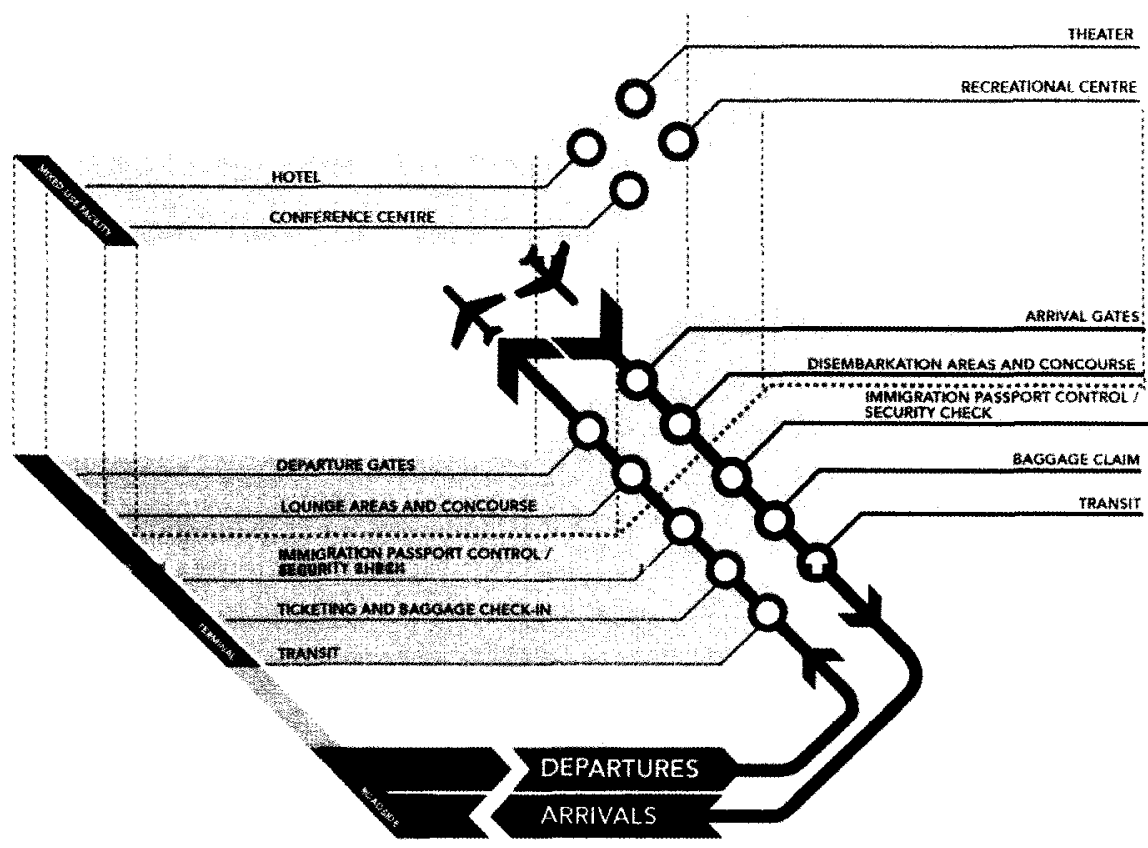

FIGURE 28. DIAGRAM: PROPOSED LAYOUT

${ }^{68}$ Gillian Fuller, Ross Harley, Aviopolis: A Book About Airports (London: Black Dog Publishing LTD., 2004) 20. 
The programmatic concept is based on two aspirations. The first is to re-contextualize the airport as a destination within the framework of intermodal space. The second is to embrace international space as territory of commingling and cultural engagement.

\section{AIPORT AS TERMINUS}

Airports have traditionally existed as transient spaces of city infrastructure. Much like a train or bus station, "an airport is an intermodal space. It's a transfer space. It facilitates the movement of passengers and cargo." ${ }^{169}$ However, with the expansion of terminal systems and autonomy of airport management, "airports are becoming more than just places to catch your plane."70

"[Airports] are becoming [...] cultural environments. And I think we are seeing a great shift in the way we think about culture and the way we present culture to people. We are moving beyond institutions."

- Lee Petrie, Manager, Cultural Programming, GTAA

Prompted by the localization of airport management - from federal jurisdiction to private enterprise - terminal space has transformed into a venue for economic development. As a result, one of the greatest challenges faced by the Canadian airport industry is international competitiveness. ${ }^{71}$ Airport operators are compelled to provide incentives for both passengers and businesses. These can range from the practical to the surreal. Singapore International Airport, for instance, provides themed environments, spas, pools and lounges as a respite for its traveling patrons. ${ }^{72}$ These functional examples exist as dereitic devices, intended to detach the user from direct experience. As alternatives to conventional waiting areas, these leisure amenities are deferential to airport operations.

The terminal project proposes a new approach to economic and functional development within the airport. A dedicated conference and mixed-use facility re-contextualizes the terminal as a destinative building type in addition to being an intermodal facility. While airport functions may continue uninterrupted, the conference centre provides formal facilities for scheduled events. In this way, the airport may exist as a destination within the terrain of international space. The effect would establish the $3^{\text {rd }}$ space as an autonomous territory, a unique 'place' of identity and global competitiveness.

\section{AIRPORT AS CULTURAL CONVERGENCE}

The nature of airport operations demand a rigorous framework of programmatic order. To ensure functional performance, circulation is limited to a linear sequence of processing. Movement is controlled through systems of signs, boundaries and checkpoints. These controlled environments, aptly described by $20^{\text {th }}$ century philosopher Henri Lefebvre as abstract spaces of 'lived obedience', contain users in a static formation. ${ }^{73}$ Interaction is restricted or limited to designated areas.

\footnotetext{
${ }^{69}$ Shaw personal interview.

${ }^{70}$ Lee Petrie, Manager, Cultural Programming, Greater Toronto Airport Authority GTAA, interview by author, 24 October 2007.

${ }^{71}$ Gooch, interview by author.

${ }^{72}$ Fuller, Harley 116.

${ }^{73}$ Henri Lefebvre, The Production of Space trans. Donald Nicholson-Smith (Massachusetts: Blackwell

Publishers Inc., 1992) 143.
} 
The nature of international space, however, presents an opportunity to coalesce a diverse group of international travelers. The boarding gate, as the threshold from aircraft to terminal, is the veritable gateway to an international community.

"Pearson Airport is a global village. It's a global village with people from every nation, every background, every language, every culture."

- Peter King, Fellowship Chaplaincy Services, Pearson International Airport.

While the proposed programmatic concept does not dismantle the structure of airport systems, it does provide an alternate forum for social convergence and engagement. The conference facility, as a construct within the territory of international space, facilitates the intersection of users through a collaborative, multi-purpose environment. Performances, symposia, cultural programming and gallery exhibitions offer venues for exchange and commingling.

"It's the commingling. You meet an interesting person and I like that. I think that is part of the travel experience. You do rub shoulders with other people. I wouldn't want to be too separated from that"

- Steve Shaw, Vice President, Marketing and Business Development, Greater Toronto Airports Authority (GTAA)

\section{PROGRAMMATIC CONCEPT CONCLUSIONS}

The programmatic proposals are strategies to anticipate modalities of function and spatial relationships. The formation of airport as terminus manifests the $3^{\text {rd }}$ space as a distinct 'place' within the zone of non-nation territory. Proposed conference facilities present unique opportunities for economic development and global competitiveness in the context of airports as private enterprise. The proposed programme spaces also embrace the latent value of airport space as the territory for cultural convergence. Detached from restriction of geographic, ethnic and political boundaries, the $3^{\text {rd }}$ space can provide an ideal venue for cultural, and social exchange.

\subsection{2 // MASTER PLANNING CONCEPTS}

Within the context of the airport site, there exist conditions that shape a range of master planning challenges. Airlines, airport businesses, government agencies, airport users, community groups and the general public all contribute to development guidelines. In addition to a terminal design, this thesis proposes a series of master plan initiatives that re-examine land use and development in the context of the new programmatic concepts. This exercise is approached as an extension to the theoretical framework of the architectural design. These concepts can be described relative to three component systems common to any contemporary airport layout. They include Terminal Systems, Airside Systems and Roadside Systems. 
TERMINAL SYSTEMS (SEMI-PUBLIC AND SECURE)

Facilities designed for the movement, processing and holding of passenger and cargo between aircraft and groundside networks.



FIGURE 29.

Passenger Terminals

Parking Facilities

Infield Terminals

Cargo Terminals

\section{AIRSIDE SYSTEMS (PRIVATE, SECURE ZONE)}

A dedicated network to facilitate the movement and operation of aircraft, specialized support vehicles and authorized personnel. The capacity of this system defines the scale of all subsystems including terminal systems, and groundside access.

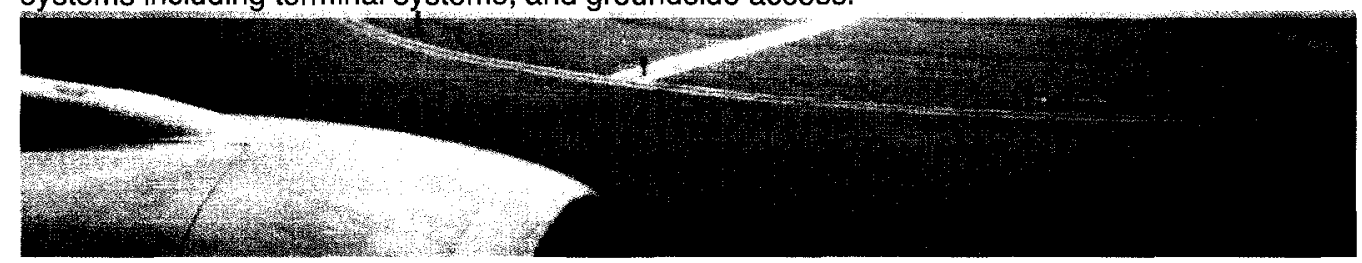

FIGURE 30.

Control tower

Apron

De-icing Pads

Taxi-ways

Runways

Tunnels and Service Roadways

Emergency access roads

Glide path, localizer, Doppler Distance Measuring Equipment

Terminal Surveillance Radar

Airport Surface Detection Equipment.

Navigational and Visual Approach Aids

Maintenance Facilities 


\section{GROUNDSIDE SYTEMS (PUBLIC SPACE)}

A network for the automobile, bus and train. The infrastructural link composed of all systems that connect passenger terminal facilities to the Greater Toronto Area (GTA) transportation network.

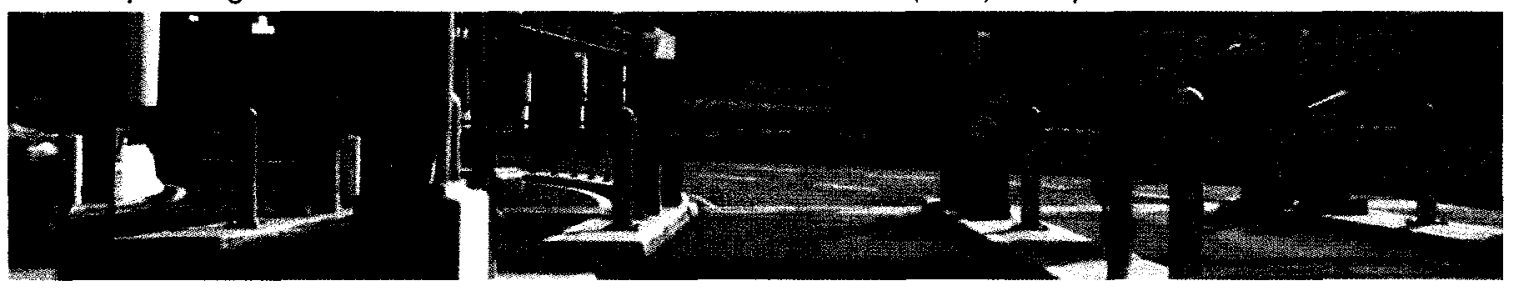

FIGURE 31.

Roadway Access (terminal and conference centre)

Parking Facilities (short and long-term)

Rental Car Facilities

Public Transit

LINK train

Ground Transportation

RAIL link

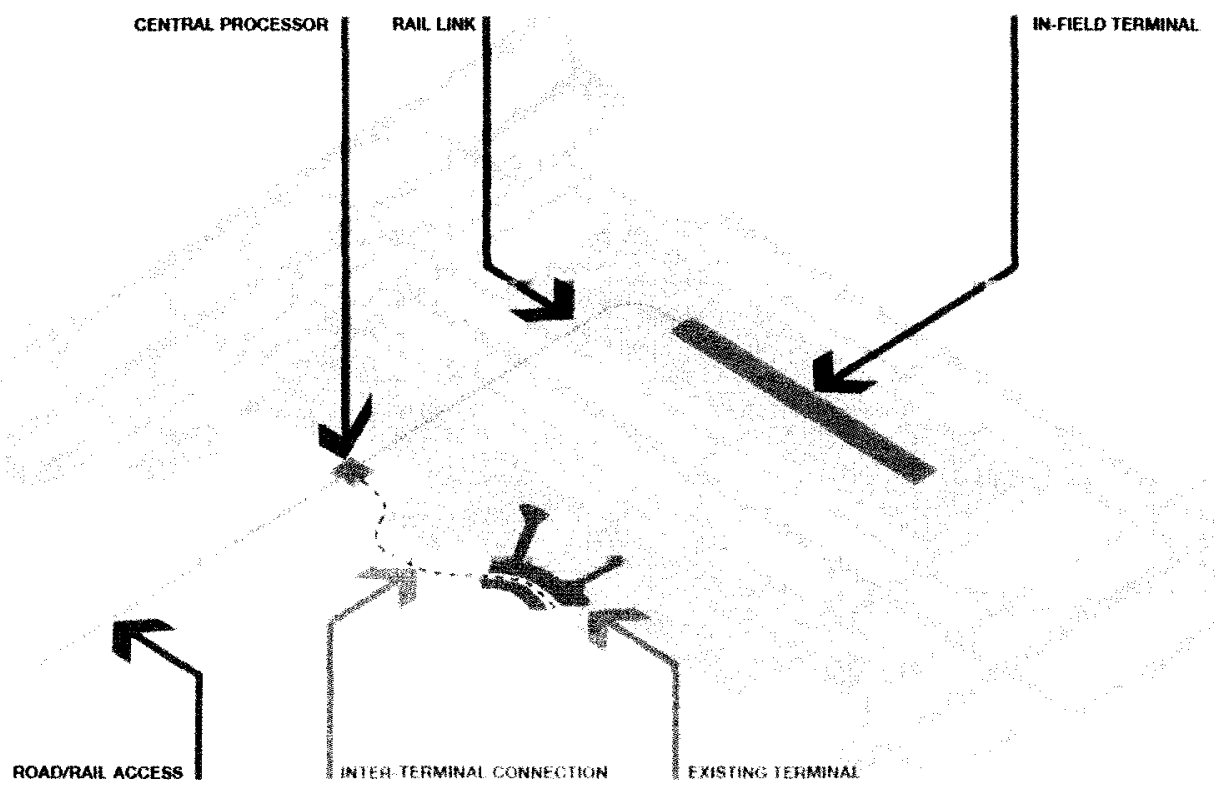

FIGURE 32. MASTER PLANNING CONCEPTS

\section{A_PROPOSED TERMINAL SYSTEMS}

To address conceptual and functional concerns, the new international passenger terminal is proposed within the in-field space of the airport lands. For this to occur the terminal is split into two components. The first, a central processor, acts as the main entry and interface between terminal and city-transport infrastructure. (part 3.3.3.2) The second, an in-field, satellite component, houses all major programmatic elements such as conference centre and international boarding facilities. These constituent sections are connected by an underground rail link. 


\section{IN-FIELD TERMINAL}

Conceptually, the purpose of a satellite terminal is to enable the architecture to identify itself as an autonomous expression. An explicit separation between groundside and airside experiences is exaggerated by the entry sequence of an underground rail link. Detached from the access roads that interconnect terminal to city, the in-field built form exists exclusively within the airside territory. Encircled by aircraft of diverse origin, the terminal aligns theoretically with the notion of architecture of international space. It is within this space that the building design may develop as a unique identity.

Functionally, the benefits of an infield terminal are numerous. Existing location of runways and taxiways circumscribe the 143 ha (352 acres) territory. ${ }^{74} \mathrm{~A}$ passenger terminal constructed here is centrally located within the airside system and provides minimal taxi distance for arriving and departing aircraft. The satellite space is also directly adjacent to an existing de-icing facility. The cumulative effect results in more efficient movement of aircraft, economizing fuel consumption and decreasing passenger wait times.

From the standpoint of security and control, an in-field construction has conceptual and functional implications. Due of surrounding runways, structures within this area have limited points of access. Dedicated underground roads and tunnels provide the only effective means of entry and egress. These controlled routes regulate the nature and magnitude of movement. On ground level, in-field construction must prescribe to height restrictions that maintain expansive sight lines. ${ }^{75}$ Overall, these qualities are characteristic of an in-field space that is highly secure and surveilled. Since this space lies on the periphery to the gateway of Toronto and, by extension, Canada, it is enforced as a border condition. ${ }^{76}$ The placement of a passenger terminal at the centre of the in-field space is affirmation that architecture of this territory is encircled by the limits of a secure, monitored environment. While this degree of surveillance does not extend to the internal organization of the terminal, it does apply to the sequences of approach and egress.

The master planning stage establishes general guidelines for building footprint and overall proportions of the satellite terminal. For reasons that relate to conceptual and functional concerns, the architecture prescribes to a linear, rectangular footprint. These geometric boundaries are analogous to the larger limits that exist between the terminal space and airside space. They express an explicit terminus and bound containment of the internalized functions. A linear terminal is also a required layout for efficient gate operations. All International terminals share common equipment. Airlines require that gates operate in the same manner regardless of location. ${ }^{77}$

"A flight can be Air Canada this hour or United the next hour and the equipment's common. And that is a very big asset. [...] Airlines come in and it's literally plug and play."

-Steve Shaw, Vice President, Marketing and Business Development, Greater Toronto Airports Authority (GTAA)

A linear design accommodates these requirements and is flexible to changing scales in aircraft design and equipment. Lastly, the in-field site condition naturally supports a linear terminal within its 143 ha (352 acres) rectilinear area.

\footnotetext{
${ }^{74}$ GTAA "Airport Development Program," Taking Flight 5.

${ }^{75}$ Edward G. Blankenship, The Airport: Architecture, Urban Integration, Ecological Problems (London: Pall Mall Press, 1974) 17.

${ }^{76}$ Shaw, personal interview.

${ }^{77}$ Shaw, personal interview.
} 


\section{CENTRAL PROCESSOR}

The central processor is the built form between Canadian territory and international space. It is fed by the groundside systems and is located adjacent to existing terminals and access roads in the Airport East Lands. This facility is the primary processing and screening area for travelers and conference delegates. Major programmatic elements include the main ticketing hall, primary security screening, customs-and-immigration, greeters' hall and baggage claim. Within conventional airport designs, the central processor has existed as the most prominent built component. This is largely driven by the vast space requirements for ticketing and check-in. These areas are often accommodated through large span ceilings and generous floor areas. Advancements in processing technologies have led to the automated check-in system. Online services and electronic kiosks are replacing the conventional check-in counter. ${ }^{78}$ As a result, the spatial requirements for the ticketing area are vastly diminished. Architecturally, this is changing the character of the departures hall. ${ }^{79}$ The design of the central processor reflects this phenomenon. The economized ticketing area has reduced physical prominence. Conceptually, the intent is to express the transient nature of this processing facility and translate architectural emphasis to the in-field conference centre and boarding areas.

\section{ADDITIONAL PROPOSALS TO TERMINAL SYSTEM}

- Maintenance of existing T3.

- Executive aircraft terminal.(closer to city roadways, shortened travel distance from downtown Toronto.

- Cargo facilities relocated to east.

- New proposed administrative wing as part of terminal.

\section{B_PROPOSED GROUNDSIDE SYSTEMS.}

The groundside system is the connection to the Greater Toronto Area (GTA) transportation network. Roadways facilitate access to provincial highways (409/427/401) and local roads from arrival, departure and conference levels. Parking is supplied through two facilities. A conventional garage accommodates travelers as well as conference delegates. An additional facility provides automated parking for long-term travelers. To improve accessibility, a highspeed rail link is proposed.

\section{MULTI-PURPOSE GARAGE}

Located within the airport east lands, the parking garage houses approximately 8,000 spaces. Designed as a modular construction, the facility may be expanded to accommodate up to approximately 12,000 vehicles.

\footnotetext{
${ }^{78}$ Shaw, personal interview.

${ }^{79}$ David Jensen, Partner and Joint Venture Representative, Adamson Associate Architects, personal interview, 13 February 2008.
} 


\section{AUTOMATED PARKING}

As a supplement to the conventional garage, the automated parking facility supports roughly 2,000 spaces. Passengers drop-off and retrieve vehicles at designated queuing areas. A computerized conveyance system stores vehicles within a secure environment. Due to load capacities, this facility is most suitable for long-term parking.

Advantages over a conventional garage include:

- reduced building footprint and environmental impact.

- reduced travel distance for passengers.

- improved security.

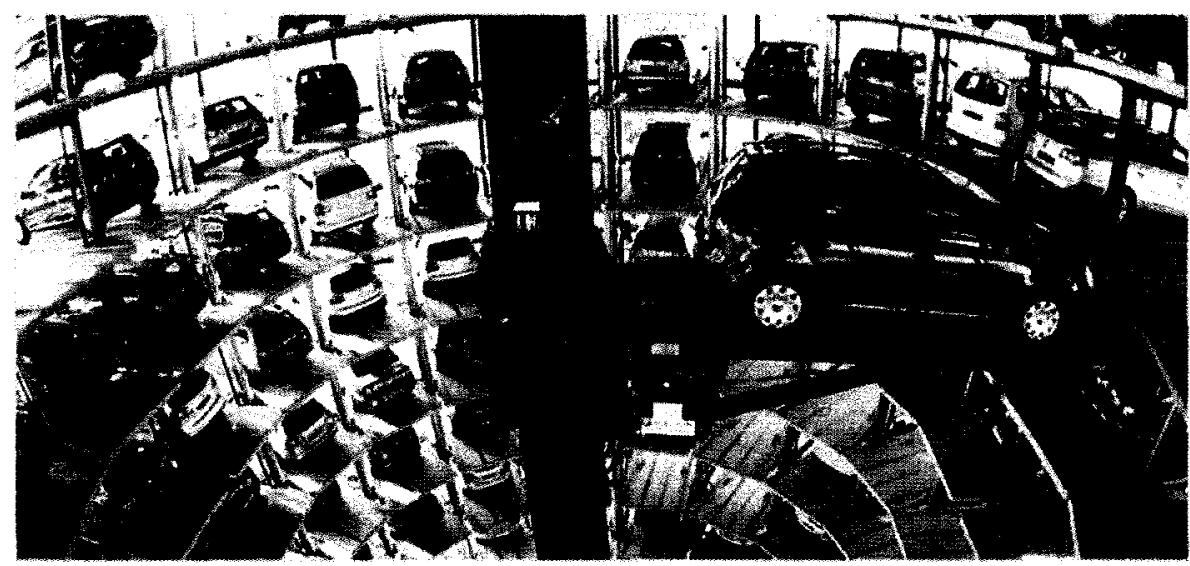

FIGURE 33. VW Automated Parking, Autostadt. Wolfsburg, Germany.

\section{RAIL LINK}

To reduce dependence on road transportation, a high-speed rail link provides improved access to the metropolitan area and surrounding regions. As per the recommendations of a Transport Canada feasibility report, the system integrates within the $\mathrm{CN}$ rail Weston subdivision via the $427 / 409$ corridor. ${ }^{80}$

\section{GROUNDSIDE SYSTEM CONCLUSION}

While these strategies address functional requirements, the conceptual implications are significant. The groundside system is a complex network infrastructure that radically alters the notion of arrival. There is no front door to the airport in any conventional sense. Entry may occur from many levels. While expansive in scale, the system initiates the sequence of arrival through a compression of space. Users are filtered into a series of functional categorizations. (i.e. arriving, departing, international, domestic.) Through these initial forms of processing, the groundside system prepares users for further screening. (i.e. ticketing, check-in.) The architecture and groundside system thus simultaneously exist as forms of network space. Subsequently, the boundary between architecture and infrastructure is blurred and the notion of arrival becomes indistinct.

\section{PROPOSED AIRSIDE SYSTEMS}

The proposed airside developments provide improved aircraft movements and higher overall capacity. A new east-west runway is proposed parallel to the existing Runway 05-23. At approximately 3,300 metres $(11,100 \mathrm{ft})$ in length, the new runway is able to accommodate the largest wide-bodied passenger aircrafts. Based on the findings of a Greater Toronto Airport Authority (GTAA) planning report, the addition of a sixth runway would increase the airport

${ }^{80}$ Transport Canada, Rapid Transit Access to Lester B. Pearson International Airport: Final Report By IB| Group. February 1999. Transport Canada. 20 June 2008. 34. <http://www.georgetownpearsonstudy.ca>. 
capacity by $10-15 \%$, translating to an increase in up to 9 million passengers annually. ${ }^{81}$ Highspeed exit taxiways allow landing aircraft to quickly vacate runways, allowing higher hourly movements. The new proposed east-west runway integrates this construction while the existing 15R-33L runway is upgraded. A dual taxiway system around the passenger terminal area achieves higher efficiently by allowing bi-directional movement of aircraft. To ensure the safe operation of aircrafts during winter months, a large de-icing facility is proposed within the in-field. Consisting of 6 anti-icing pads and support area, the facility may accommodate the simultaneous deicing of 12 wide body aircraft or 24 narrow-body aircrafts.

Provide increased capacity.

- taxi-way enhancements (high speed exit taxi-way, and dual taxiways)

- de-icing upgrades (re-orientation and expansion)

- Runway 33L extension (larger aircraft capacity)

- New N-S runway (improve airport capacity)

\section{MASTER PLAN CONCLUSION}

The master plan works within a conceptual framework while addressing functional complexities. Expanded runways and enhanced taxiways provide increased capacity in the airside system. Groundside upgrades reduce travel distance for passengers while integrating more diverse transit systems to enhance access. Proposed terminal systems improve passenger experience with automated services and advanced security measures. Conceptually, the planning approach distinguishes between transient space (central processor and groundside systems) and holding space (in-field terminal). The groundside and central processor reflect their nature as intermodal processing and screening spaces within a larger networked system. Movement is restricted within a compressed space. Users travel within designated areas along linear paths. An in-field, satellite terminal expresses an international space which is terminal, holistic and autonomous. Restriction is released within its secure environment.

\section{PART 03.4}

\section{DESIGN / ARCHITECTURAL CONCEPT}

\subsection{1 // GENERATIVE CONCEPT}

The architecture of the airport resides within a non-place, outside the boundary of Canadian and international borders. The initial concept is concerned with generating architecture that is shaped through its own nature and internal experiences rather than the outward influence of style, representation and form. One architect who works with similar objectives is Peter Eisenman. His writings and projects provide the frame of reference for the methodology towards an architecture of international space.

\subsubsection{1 // THEORETICAL CASE STUDY}

Peter Eisenman is an American architect who has worked to liberate architectural form from external meaning. In an article for Perspecta published 1982, Eisenman argues that architecture - since the $15^{\text {th }}$ century - has not successfully managed to reflect cultural history, reason and representation. Eisenman describes this manifestation in architecture as the fictions of a classical approach. ${ }^{82}$ The solution, as proposed in the text and later attempted in built projects, was a liberation from the fictions of meaning and truth.

${ }^{81}$ GTAA "The Airside System," Taking Flight 22.

${ }^{82}$ Peter Eisenman, "The End of the Classical: The End of the Beginning, the End of the End," Perspecta 21. (1984): 157. 
Pre-renaissance was the most recent period, Eisenman argues, where the language of architecture intersected with meaning. The difference between representation and language was indistinguishable. Since that period, however, architecture has existed as a form of 'simulacra', simulations or fictions of representations. In the case of the renaissance, works received their value from the representation of an already valued architecture. Architecture had thus transformed into a message rather than a meaning. ${ }^{83}$

In a historical context Eisenman describes the emergence of the zeitgeist and conception of past and present as factors that erase truth and meaning from architecture and language. Expression is suddenly compelled to find justification within past and futures rather than existing as a simple declaration of itself. Meaning and truth is transformed from a straightforward 'existing as' to a process of 'reference too'. ${ }^{84}$ Still, even the assertion of modernism falls into a fiction of history as it attempts to represent the truths of its zeitgeist. This pursuit, Eisenman argues, cannot occur as a principle purpose as it is an inevitable factor of any period. Truth and meaning exist as subjective notions. Timelessness, Eisenman concludes, is the only objective predetermination in architecture. $^{85}$

Eisenman presented these arguments to instigate a new conception of architecture, one that is detached from the fictions of representation. Instead, it may more appropriately be described as an 'other manifestation', an architecture 'as is', now as a fiction. It is a representation of itself, of its own values and internal experience. ${ }^{86}$

To this end, Eisenman works to eradicate external values, and experience. The most significant relate to the origins of architecture in what Eisenamn terms as the classical concepts of 'beginning' and 'end'. 'To begin' and 'to end', in this case, relate to the questions in architecture that asks where one starts and where one finishes. If the beginning is based in concepts of the natural, divine or universal, one automatically prescribes to external values that influence direction as well as design goals. In Eisenman's view, an architecture that is entirely selfreferential and hermetic must begin with an arbitrary origin. This starting point, it is argued, imposes no direction or prescribed closure.

"[...] because the motivation for change of state (that is, the inherent instability of the beginning) can never lead to a state of no change (that is, an end). ${ }^{.87}$

A biased origin also formalizes 'the end'. Completion is a measure of success relative to initial motives. The generative process of composition is a task of addition or subtraction, an interplay that is constantly measured against the origin. An objectified beginning, in contrast, enables a process of modification. Design becomes a non-directional process of invention and discovery.

In Eisenman's architecture the process of design is a process of research into formal structures and shapes which do not exist prior to the design. ${ }^{88}$

\footnotetext{
${ }^{83}$ Eisenman 156.

${ }^{84}$ Eisenman 162.

${ }^{85}$ Eisenman 164.

${ }^{86}$ Eisenman 167.

${ }^{87}$ Eisenman 168.

${ }^{88}$ Mario Gandelsonas, introduction, "From Structure to Subject: The Formation of an Architectural Language" House X, by Peter Eisenman (New York: Rizzoli, 1982) 10.
} 
Eisenman's objective is towards architecture as text, a spatial language read internally through a configuration of forms. Through the elimination of external values and a creative exploration of formal structures, emphasis can favour communication over representation.

"Reading [...] makes available a level of indication rather than a level of meaning or expression." 89

\subsubsection{2 // THEORETICAL CASE STUDY CRITICAL DISCUSSION}

To achieve an architecture 'as is' and 'of its own values and experiences', Eisenman makes declarations regarding approach and process. A methodology toward the architecture of airport space begins with the concepts implicated by Eisenman. They include the functional, the meaningful, and the processing.

\section{THE FUNCTIONAL}

In the struggle to develop a new language in architecture, Eisenman forfeits the task of functionality. In his defense, Mario Gandelsonas describes the modern creed of 'form following function' as not unlike the classical trappings of simulacra. Modern architecture did not derive its form from function but rather from other references such as machine technology. However, Gandelsonas concedes, Eisenman does surrender not only functionalism but humanism as well. ${ }^{90}$ By this testament, Eisenamn's objective becomes obsolete. If architecture is the text than the human dimension is the reader. Once detached from humanism, architecture loses all legibility. Suzanne Frank, a client of Eisenman's 'House VI', described her discontent in a publication written in response to the architecture. According to Suzanne, the role of architecture should include the provisions for basic inhabitation. "There were some decisions - sometimes involving unpleasant confrontation - that caused us inconvenience and discomfort." Eisenman's own admission, "the house is not an object in the traditional sense [...] but more accurately a record of a process." ${ }^{92}$ Within this rational, function is subordinate to formal structures.

Airport design cannot exist within this framework. The challenge of airport architecture is, in part, about creating a functional environment. Functionality is a consequence of a design process that is considerate of the human dimension.

\section{THE MEANINGFUL}

To create architecture as an autonomous representation, Eisenman resolves to detach external values from the design process. With a proposed arbitrary origin, "one that has no external value derived from meaning, truth, or timelessness", architecture can achieve a pure expression. ${ }^{93}$ In this manner, Eisenman claims, architecture may become a manifestation of its own being in a timeless expression.

External values first infiltrate the path of architectural conception at its earliest beginnings. Eiseman describes these classical starting points as sourced from deductive reason, divine, natural and universal orders. These concepts are subjective notions. "There is no one meaning, there is no one truth" Eisenman proclaimed. ${ }^{94}$ By extension, one may argue that there is no one

\footnotetext{
${ }^{89}$ Eisenman 172.

${ }^{90}$ Gandelsonas 8.

${ }^{91}$ Suzanne Frank, Peter Eisenman's House VI: The Client's Response (New York: Whitney Library of Design,1994) 54.

92 Frank 23.

${ }^{93}$ Eisenman 167.

${ }_{94}^{94}$ Eisenman 164.
} 
architecture. The act of building is in itself a subjective experience, an interpretation of the senses. However, in his pursuit of a language of form, objectifying architecture is precisely Eiseman's aspiration. One author described Eiseman's approach as "a method to apply syntactic criteria and definition to a formal structure. ${ }^{.95}$ Mario Gandelsonas, in an essay on Eisemnas theories, admits the elimination of meaning in architecture is an impossible task..$^{96}$ Therefore, if meaning is subjective then architecture is subjective because there is no architecture without meaning.

Eiseman stresses the 'not-classical origin' as a method to accomplish the ontological and timeless in architecture. The 'not-classical origin' is chiefly described as a starting point that is without value. Creating architecture that is devoid of external value is the creation of a timeless architecture, argued Eisenman, "a timeless space of invention". Timelessness in defined in the strictest sense. Literally, something of no specific time.

"[...]Timeless space in the present without a determining relation to an ideal future or to an idealized past. ${ }^{197}$

Eiseman's argument for the ontological nature in architecture runs parallel to the parameters of timelessness. Like the timeless, architecture 'as-is' and 'of its own being' can only exist when it is absent of external influence.

In his methods, Eiseman attempted to objectify architectural language through the subtraction of external meaning. With the proposed 'arbitrary origin, Eisenman could accomplish the timeless and ontological expression in architecture. The approach to international architecture takes a different attitude towards meaning, timelessness and nature of being. The architecture of international space does not begin, as Eisenman might suggest, with an arbitrary starting point. External meaning is neither sought nor unsought. Through a constant evaluation and re-invention of operations, function, site and use, airport architecture can achieve both a timeless and ontological expression.

\section{THE PROCESSING.}

Along with the elimination of a valued origin, Eisenman argued for a creative process that excluded any predetermined goal in the design development. A conventional process - termed by Eisenman as the 'classical' approach -- exists within a framework of addition and subtraction. Architectural development is a directed process toward a fixed objective. The creative process, however, is a strategy of manipulation and metamorphosis. Schematic forms undergo a series of operations which produce unexpected results. Architecture is no longer a controlled conception but rather a process of discovery and invention. Luca Galofaro, a collaborator of Eisenman, describes this technique as "a long speculative process that leaves tracks and opens up other feasible paths." ${ }^{\text {"98 }}$ This method can be illustrated through Eiseman's proposal for the University of Geneva's Library. In this example, diagrammatic models of human neurological data are superimposed to derive design constraints. The tracings of the various diagrams form the boundaries of space. (Figure 34,35 )

\footnotetext{
${ }^{95}$ Gandelsonas 8.

${ }^{96}$ Gandelsonas 10.

${ }^{97}$ Eisenman 171.

${ }^{98}$ Luca Galofaro, Digital Eisenman: An Office of the Electronic Era trans. Lucinda Byatt (Basel: Birkhauser, 1999) 27.
} 


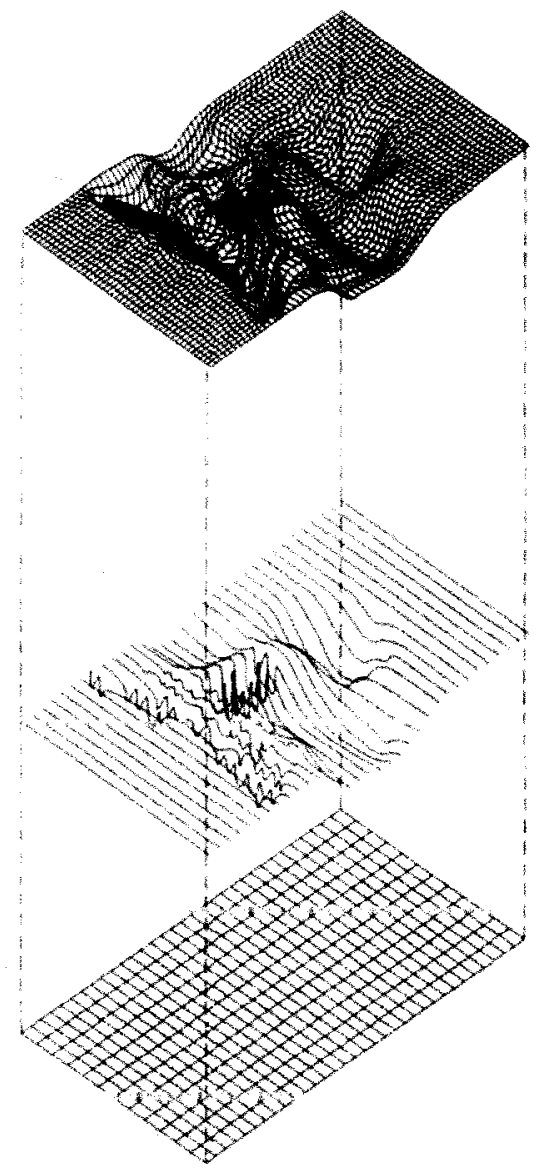

Conceptual diagrams, unification of the diagrams on memory: 1. Activity below the synaptic threshold. 2. Synaptic activity. 3. Consolidation of memory.

FIGURE 34. 

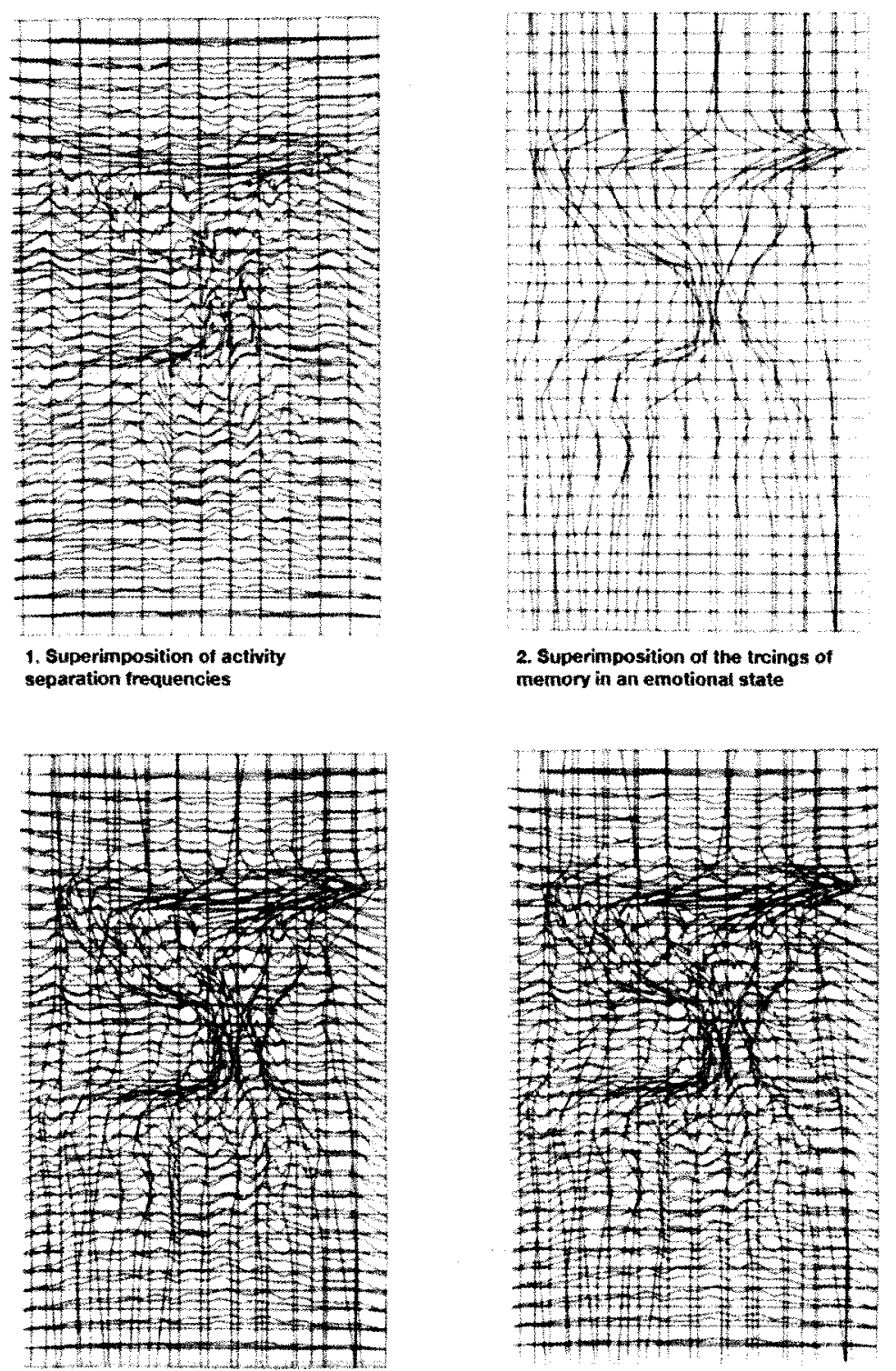

3. Superimposition of tracings of frequencies

4. Superimposition of diagrams on the site.

FIGURE 35. 

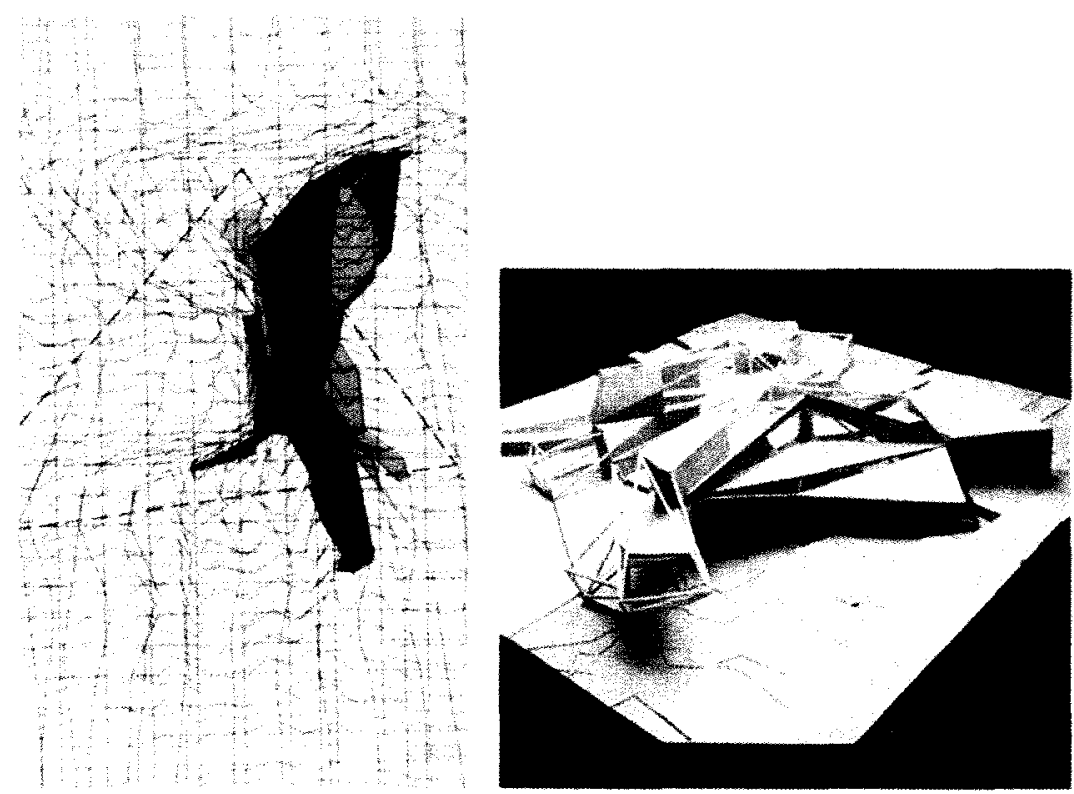

FIGURE 36. Extrapolating building form from conceptual diagrams

It is this particular aspect of Eisenamn's approach that is of interest in the conception of extraterritorial architecture. A creative process enables architectural form to reveal itself through an explorative method. A manifestation through discovery as opposed to envisioned goals. It is in this manner that architecture can achieve the expression of architecture 'as is' and 'of its own being'.

\section{THEORETICAL CASE STUDY CONCLUSION}

The purpose of the preceding section is to describe the basic framework from which the strategy of this thesis evolves. Eisenman is discussed here due to the aspects of his work that suggest the alienating dimensions of architecture. Eisenman's writings outline guidelines for the practice of architecture, principles toward a language of space. While this thesis does not promote adopting this approach as a manifesto, it does explore the appropriateness of such a method within the context of international space. The embodiment of Eisenman's concept of architecture 'as-is' and 'of its own values and internal experiences' is the ultimate goal within the isolated, non-place that is the airport territory. To achieve this, the approach to international architecture places emphasis on the creative process as a key technique. The value of a creative process, as pointed out by Gandelsonas, is the discovery and invention of form that have more significant effect on internal experience versus external measures of representation. However, in contrast to Eisenman, functional concerns represent a prominent factor in decision-making and processes. Furthermore, the notion of an arbitrary origin is revised as it is argued that architecture of 'its own values and internal experiences' can be shaped through a starting point based on the rigorous investigation into the evaluation and re-examination of operations, function, site and use. 


\section{PART 03.5}

\section{ARCHITECTURAL PROCESS}

The airport project begins with the notion of generating organizational frameworks from circulation patterns. To achieve the desired interconnection and exchange outlined in 'programmatic concepts' (Part 03.3) the architectural process starts with the mapping of programmatic sequencing. Within the context of airport operations, this process is a linear path consisting of processing checkpoints and holding areas. ${ }^{99}$ Once this general protocol is understood, opportunities for functional reinterpretation can be explored.

As previously outlined, the facility is composed of two elements. The main processor manages intermodal transfer, passenger check-in, and security screening. The in-field satellite terminal integrates boarding areas and conference facilities. Because the infield component is representative of the $3^{\text {rd }}$ space and contains the hybridized programme areas, it is the focus of conceptual strategies toward commingling and exchange. The central processor is approached as the organizer of vectors to expedite movement between the $3^{\text {rd }}$ space and city infrastructure. The remainder of this section will focus on the processes shaping the architecture of the infield terminal.

\section{MAPPING OF SEQUENCE}

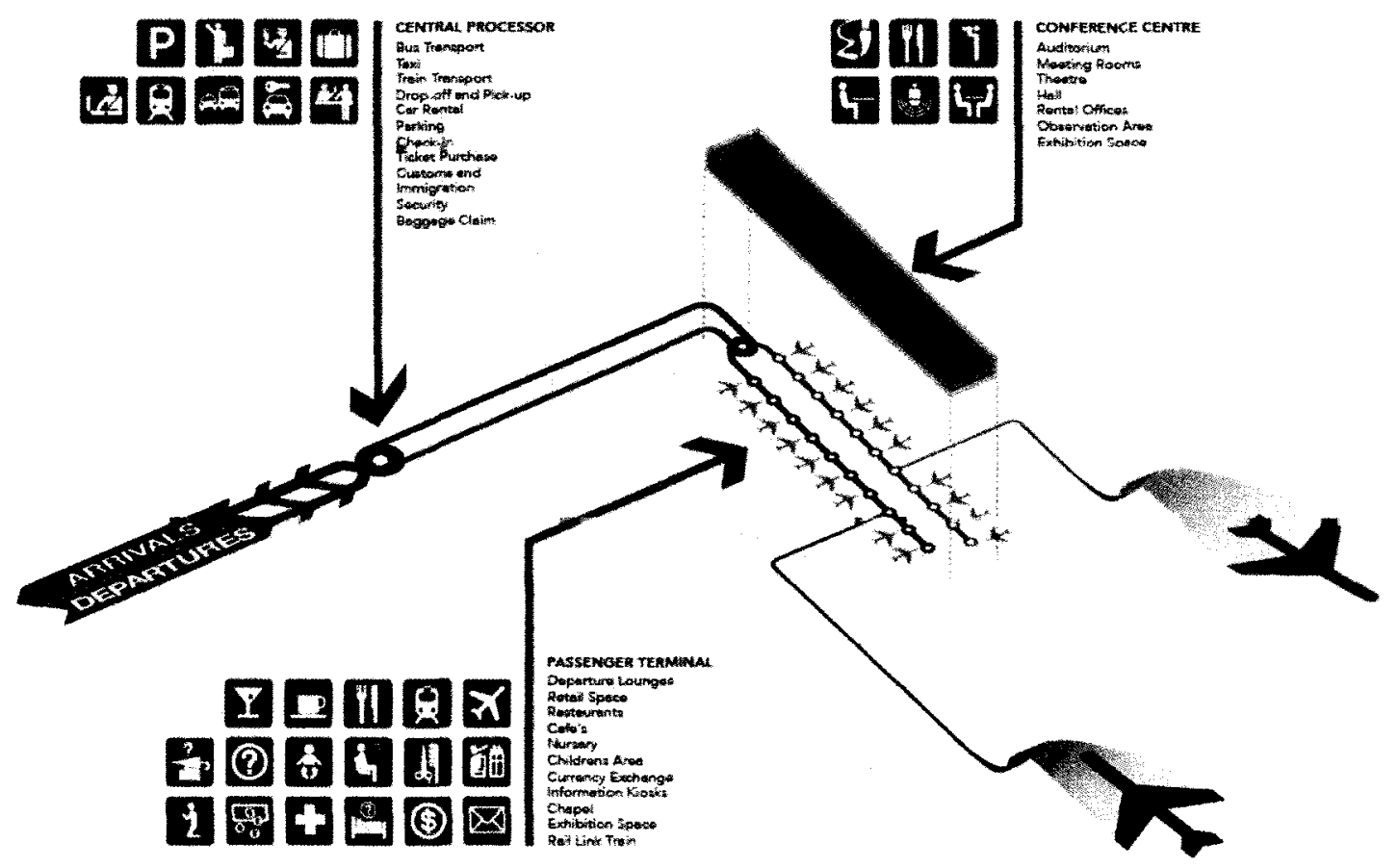

FIGURE 37.

\section{OBSERVATIONS}

The above diagram (figure 37) identifies functional zones and overall layout. A sequence of movement is classified within 3 component areas: Central Processor, Passenger Terminal and Conference Centre. From this illustration, two sets of observations can be made in regards to massing and circulation.

\footnotetext{
${ }^{99}$ Fuller, Harley 17.
} 


\section{SET 01}

1. The infield terminal (composed of mixed-use facilities and passenger operations) resides within a rectilinear footprint.

2. The terminal operations are below that of mixed-use facilities

3. Terminal operations - in passenger terminal and central processor - principally prescribe to linear circulation sequences.

\section{SET 02}

From these functional areas, several forms of circulation can be extrapolated. They are drawn from the type of movement expected from the proposed range of functional environments. They include linear movements, intersecting points, and terminal destinations.

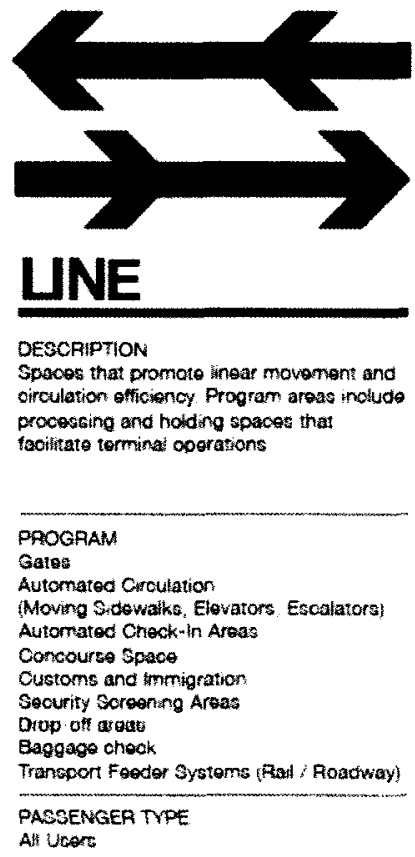

SMOOTH space

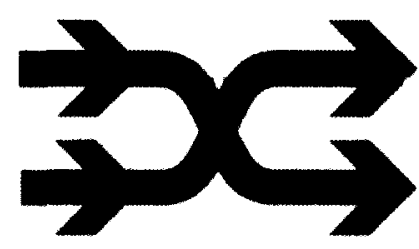
INTERSECTION DESCRPTION

Spacos that allow for the intersection of passengers and usert. This junction is croumstantial and socurs informaly. (random intersalsi program aroas are often suppiementary of adjacont to crectation spaces.

\section{PROGRAM}

Cafo

Rafe

Rastal

Exhibition I Instaktion space

Lounges

Cateteria

Amphitheate:

Bayguges Caum

Grooting Areas

\section{PASOENGER TYPE}

Business Travelars

Familiss

Large grous

En Route / Compoting Travelers (lay-oven) $\rightarrow$

ADOEO AIRPORT PROQRAM AREAS

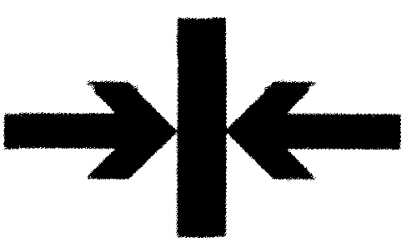

\section{TERMINUS}

\section{DESCRPTION}

Spaces that provide a doetined location tor arriving and doparting passengors. This point is premaditatod and pecurs formally (scheduled intervals) Program Arose do nor require immediate adjaconoy to primery cifculation arsas

\section{PAOGRAM}

Conterenoe Reome

Auditorium

Meater

Conosn Hall

Meeting Rooms

Hotel

\section{PASSERGEA TYPE} Bulisness Traveller / Protesaionals Employens

Campanies / Organications

Poitical Groups

FIGURE 38.

These circulation classifications provide the basic spectrum of internal organization. As originally described by Deleuze and Guattari, the nature of space embodies dimensions of both smooth and striated territory. In the strictest sense, airports have conventionally fulfilled the experience of smooth space. As transient nodes, internal operations rarely exceed opportunities of linear and intersecting spaces. By the inclusion of a mixed-use facility, however, the airport may begin to realize the striated aspects of operation. In this manner, the proposed project may better communicate the 'place' and identity of non-nation space. 


\subsection{1 // ARCHITECTURAL PRINCIPLES}

The previous set of observations (part 3.5) together with programmatic objectives (part 3.3.1.) shape a series of architectural principles from which design processes are drawn. These frameworks provide the frame-of-reference from which to measure outcomes of design concepts, and massing. Following these conclusions, a process-based exploration is undertaken to identify a range of massing concepts.

01 Interrupt Linearity

As a strategy to promote exchange, program areas must utilize formal relationships as a means to create interruption to linear movements. The linear paths of terminal operations shall be thickened, intersected and expanded to create points of intensity in the experience of airport space.

02 Generate Spatial and Programmatic Permeability

Commingling and interaction are also resultant of spatial and functional cross-programming. Porosity in formal relationships can create awareness of the hybridized operations while expanding functions beyond their physical boundaries.

03 Embrace 'Smooth' and 'Striated' Space

The integration of transient functions as well as spaces that convey sedentary function induce the greatest latitude of operation. 'Smooth' spaces - spaces of no fixed classification or boundary - manifest informal exchange while 'Striated' spaces - formalized facilities of fixed coordinates - provide a point of reference and defined identity. ${ }^{100}$

\subsection{2 // ARCHITECTURAL GENERATION}

Based on planning observation and design principles, the following set of processes was devised.

\section{Generative / Deformative Processes}

Applied to initial conceptual sketches, deformative or generative operations produce a series of formal options. Each operation is based on desired aspects of internal experience. (i.e. architectural principles previously outlined) and work within the given parameters outlined in observation set 1 (part 3.5)

\section{OPERATION: EXTRUDE}

To interconnect terminal level with conference level.

Extruded points representative of interface nodes and junctions between program areas.

\section{OPERATION: EXPAND}

To increase mass of extruded shape to accommodate larger destinative functions of conference and mixed-use facilities.

OPERATION: SLICE

To reveal the bound containment of the infield terminal rectilinear footprint

${ }^{100}$ See case study 3 , Yokohama Port Terminal. 
OPERATION: INVERT

To reveal the figure-ground relationship of the created form.

OPERATION: SECTION

To abstract form and reveal new potential relationships of connection.

OPERATION: DRAPE

To experiment with alternative surfaces that define shapes.



FIGURE 39. PROCESS PANEL 


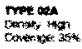

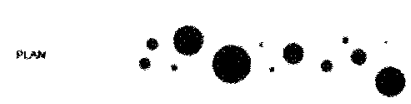

GLEMARER

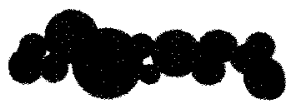

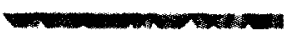
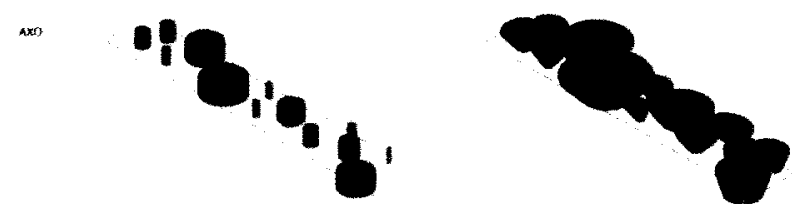

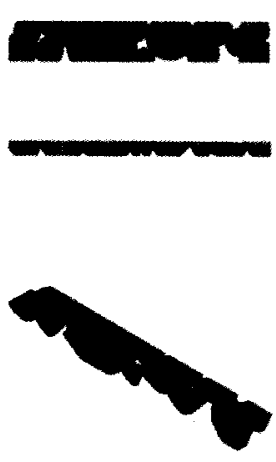

4. nio.s


FIGURE 40. PROCESS MODEL, TYPE 2A


EXIFUDE ALONG PATH
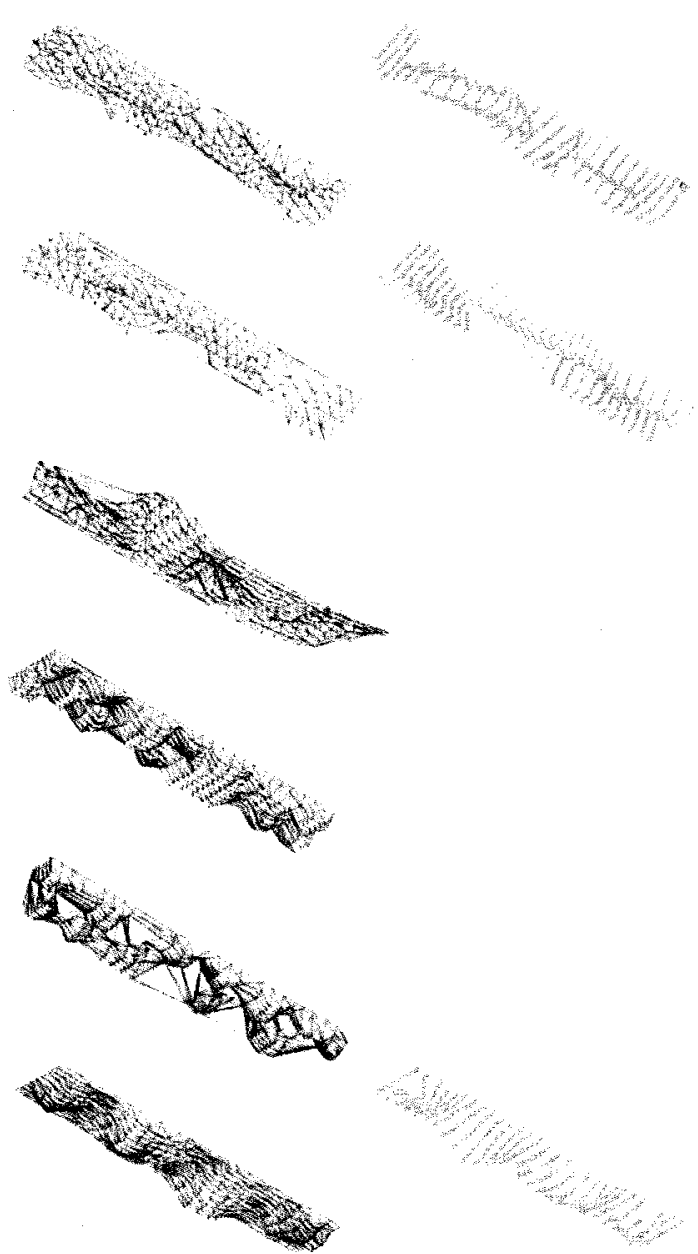

FIGURE 41. PROCESS MODELS CONTINUED 


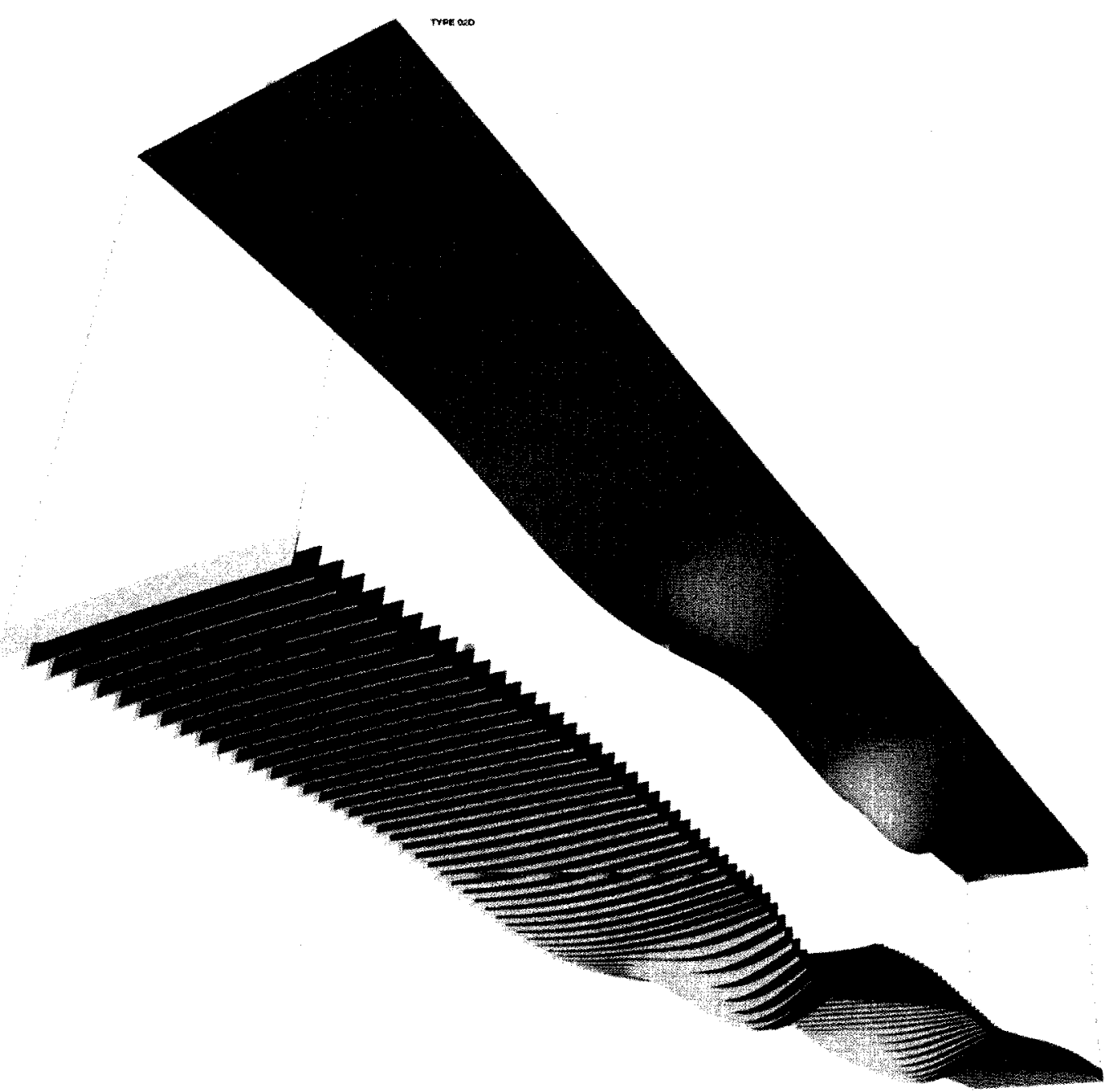

FIGURE 42. Process Modeling 


\section{Fabrication Processes}

To visualize created forms, massing options are fabricated through various mediums.

Subsequent derivatives of fabricated options are captured via 3d scanning technology.
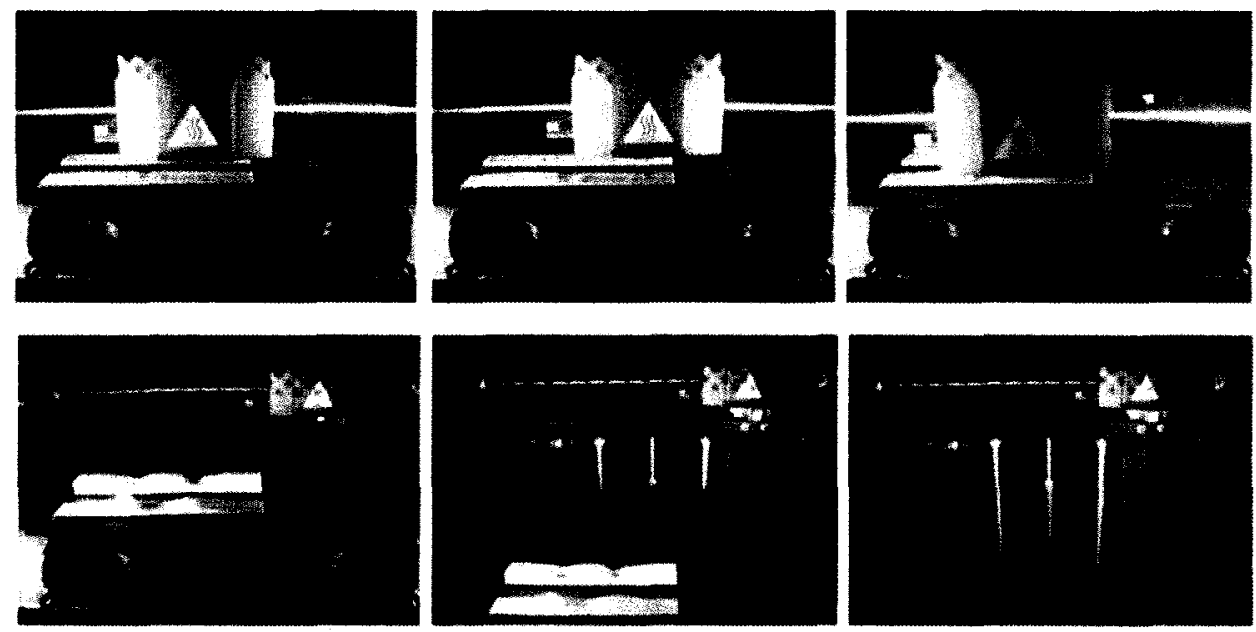

FIGURE 43. Images of 3D printer in progress.



FIGURE 44. 3D printer massing studies. (Approximate scale 1:5000) 


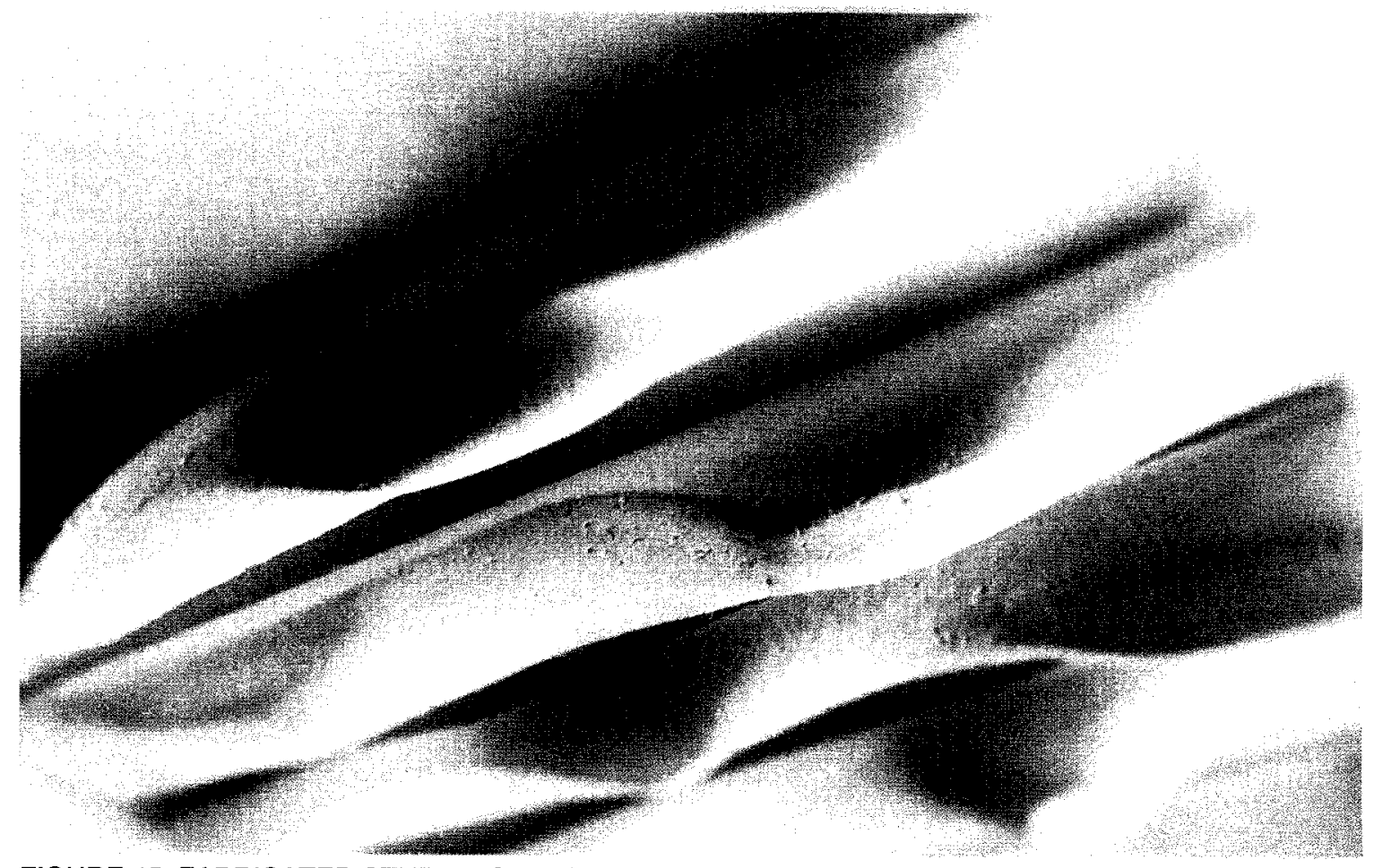

FIGURE 45. FABRICATED STUDY MODELS

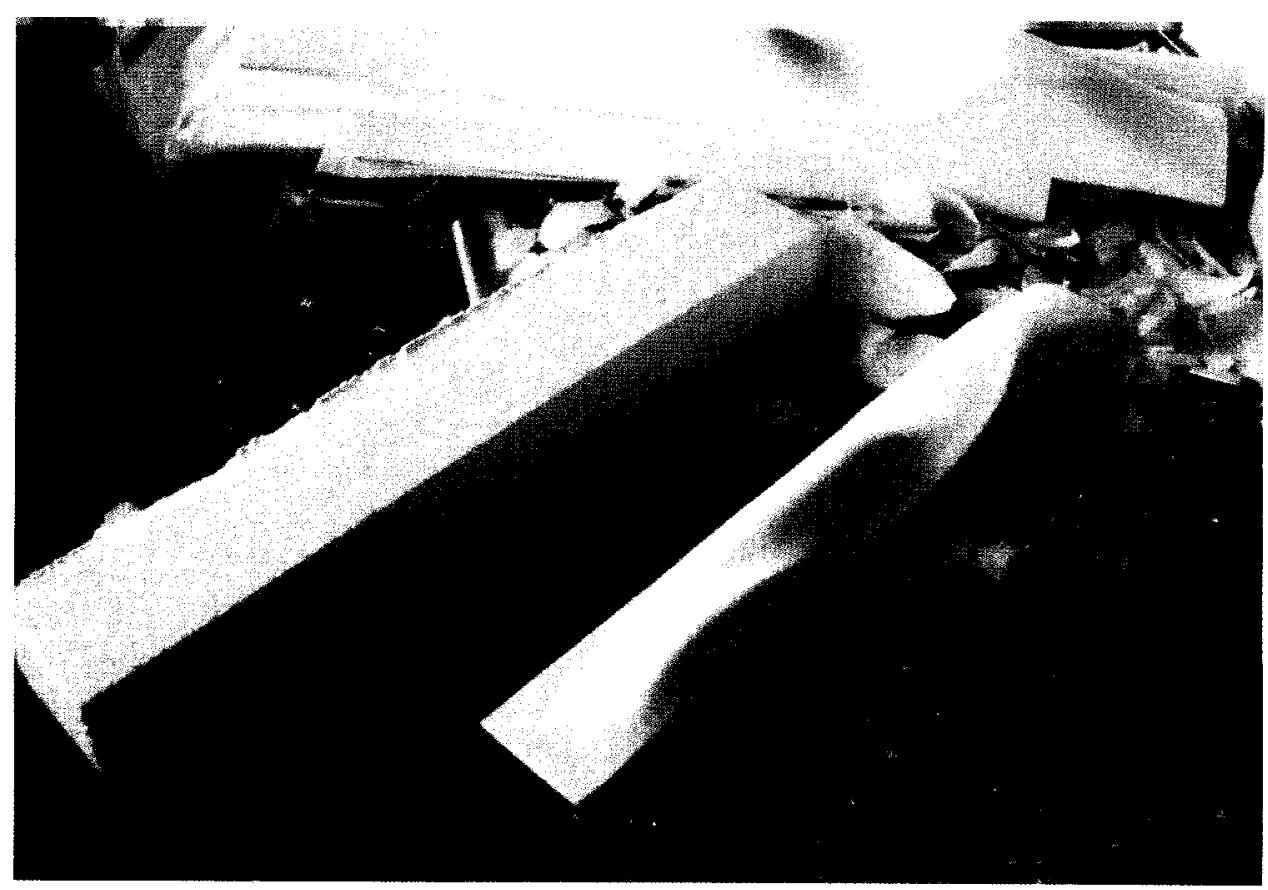

FIGURE 46. FABRICATED STUDY MODELS 


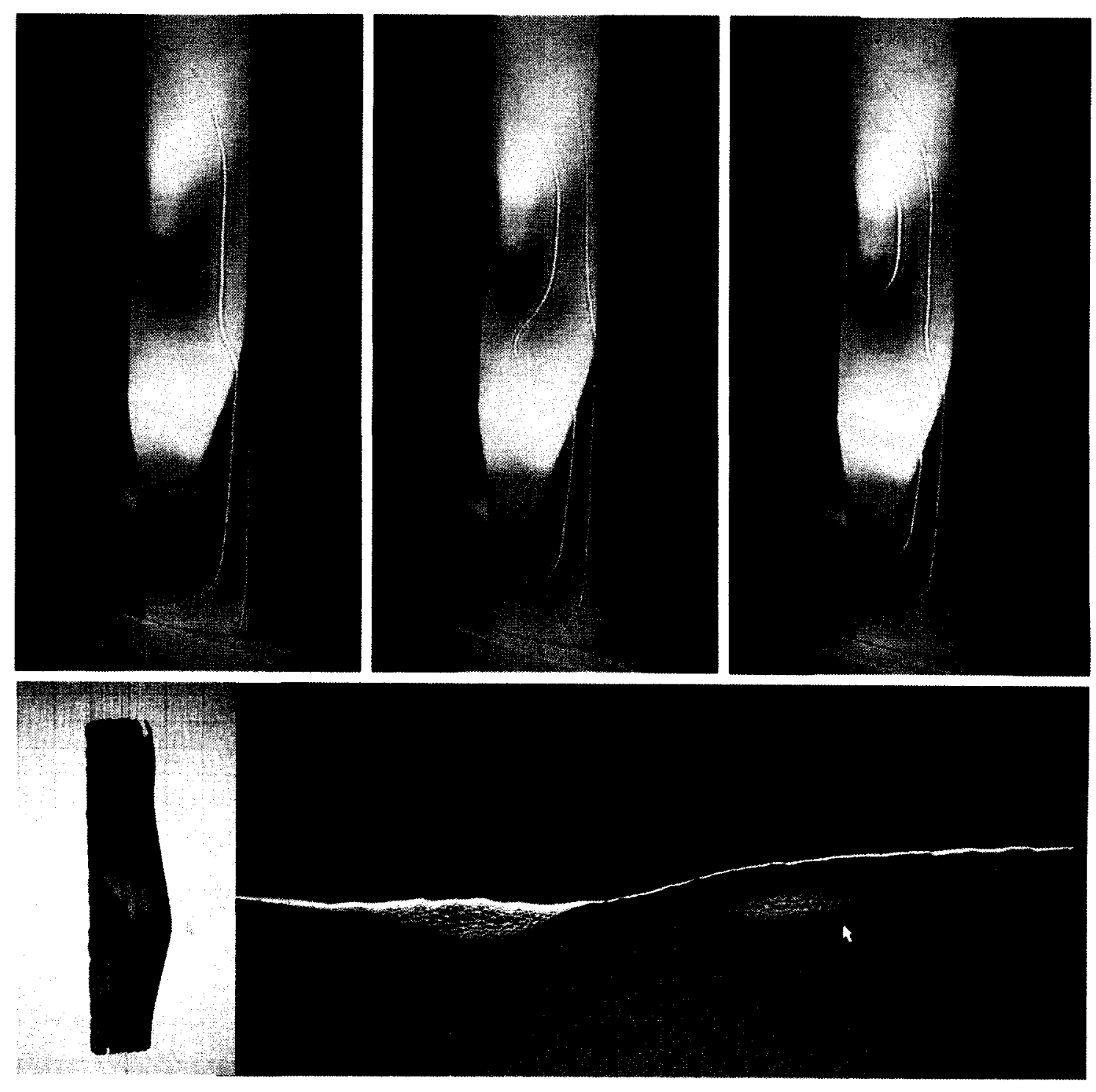

FIGURE 47. 3D Scanning of Study Models 


\section{Testing Processes}

To evaluate the schematic models, the testing process measures effectiveness of formal propositions in relationship to architectural principles and programmatic requirements.

\section{Aircraft Stand}

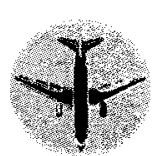

Size:

$59.5 \mathrm{M} \mathrm{o}$

Aircrafts:

B $767,6757, \mathrm{A3} 20, \mathrm{~B} 737$

M Lounge Aroa

$1 / 2805 \mathrm{OM}$

$+1 / 3,000 \mathrm{SOF}$

$M$ Concourse Width

$+10 \mathrm{M}$ $+1-30 F T$

\section{Aircraft Stand}

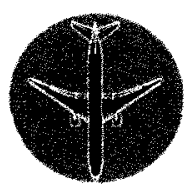

LLounge Area
$+1-3255 \mathrm{SM}$

$+3,500 \mathrm{SQF}$

1 Concourse Width

$+11 \mathrm{M}$

$+7.35 F$

\section{Aircraft Stand}

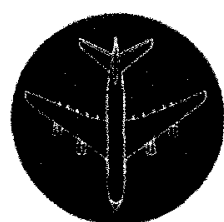

Size:

84.5M o

Aircrafts:

B747, A380

$X L$ Lounge Area

$+1-510 \mathrm{SOM}$

$+-5.500 \mathrm{SQF}$

$X \mathrm{~L}$. Concourse Widh

$+1-12 \mathrm{M}$

$+40 F$

FIGURE 48. Aircraft Stand Sizes

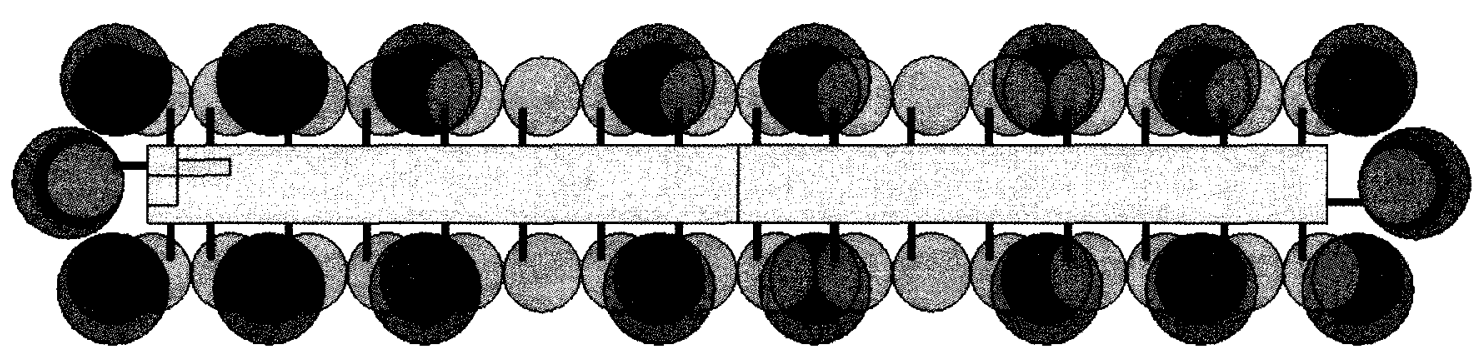

FIGURE 49. Aircraft Stand Layout, Illustrating gate variability

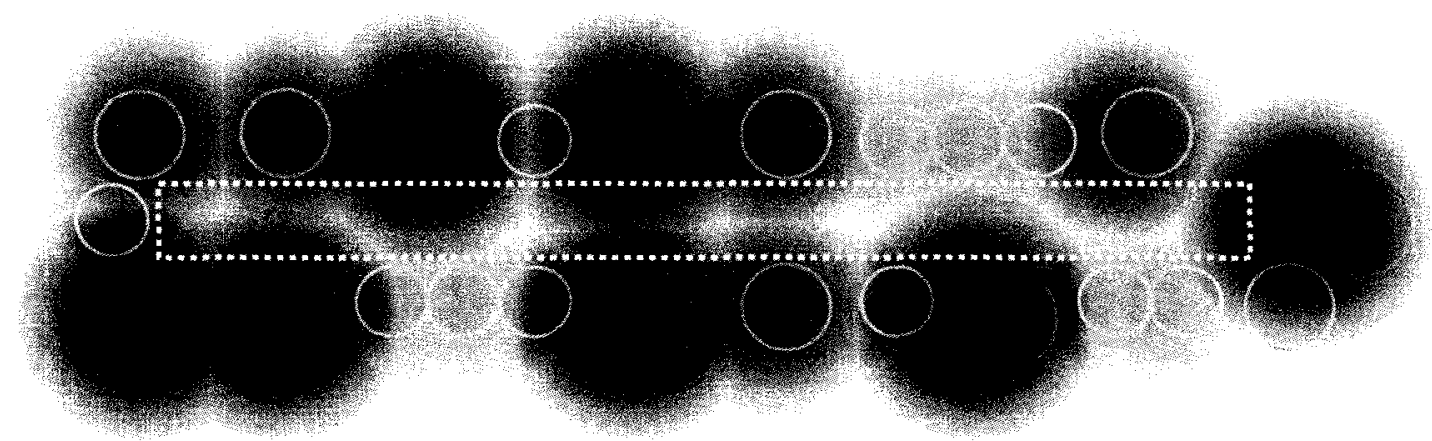

FIGURE 50. Hypothetical gate configuration and associative effect on internal spaces.

\subsection{3 // ARCHITECTURAL PROCESS CONCLUSIONS}

The generative process enables several objectives to be realized.

1. By the application of successive deformative operations, forms are neither derived from predetermined origins, nor prescribe to 'fictions' of architectural representation.

2. Through the integration of circulation and functional patterns into generative processes, the architecture is shaped through its own nature and internal experiences. Spaces achieve an 
artifactual resonance that is conceived through an independent set of values and functional relationships.

3. Fabrication processes allow alternate means of visualization. Surface, texture, structure, materiality and scale begin to emerge as additional layers for consideration. Translation from digital to physical and to digital add new forms of abstraction.

4. Testing processes, while not driving the form, provide appropriate tweaks and adjustments for optimum effectiveness and build feasibility.

\subsection{4 // FINAL DESIGN SOLUTION}

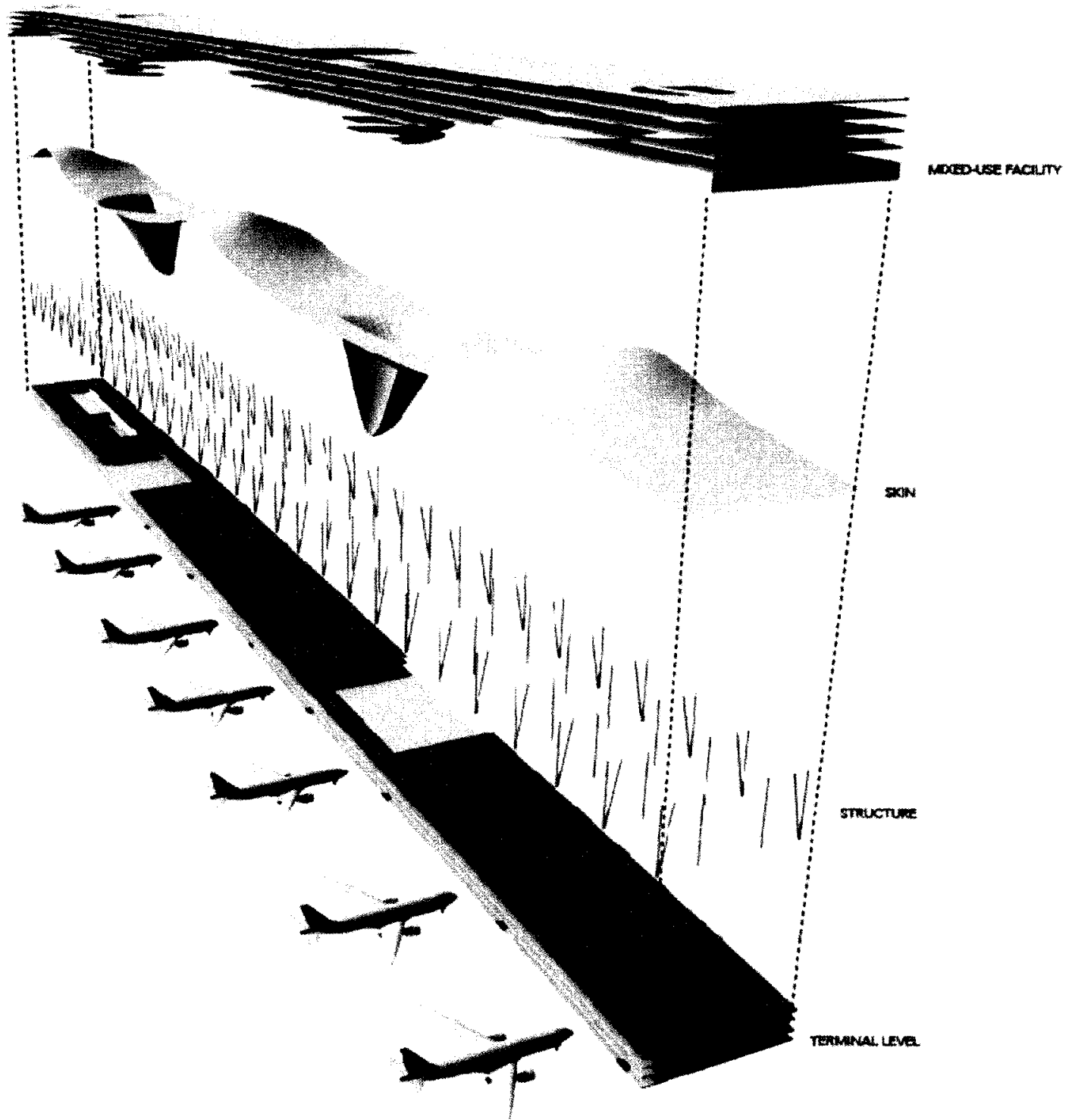

FIGURE 51. 




FIGURE 52.

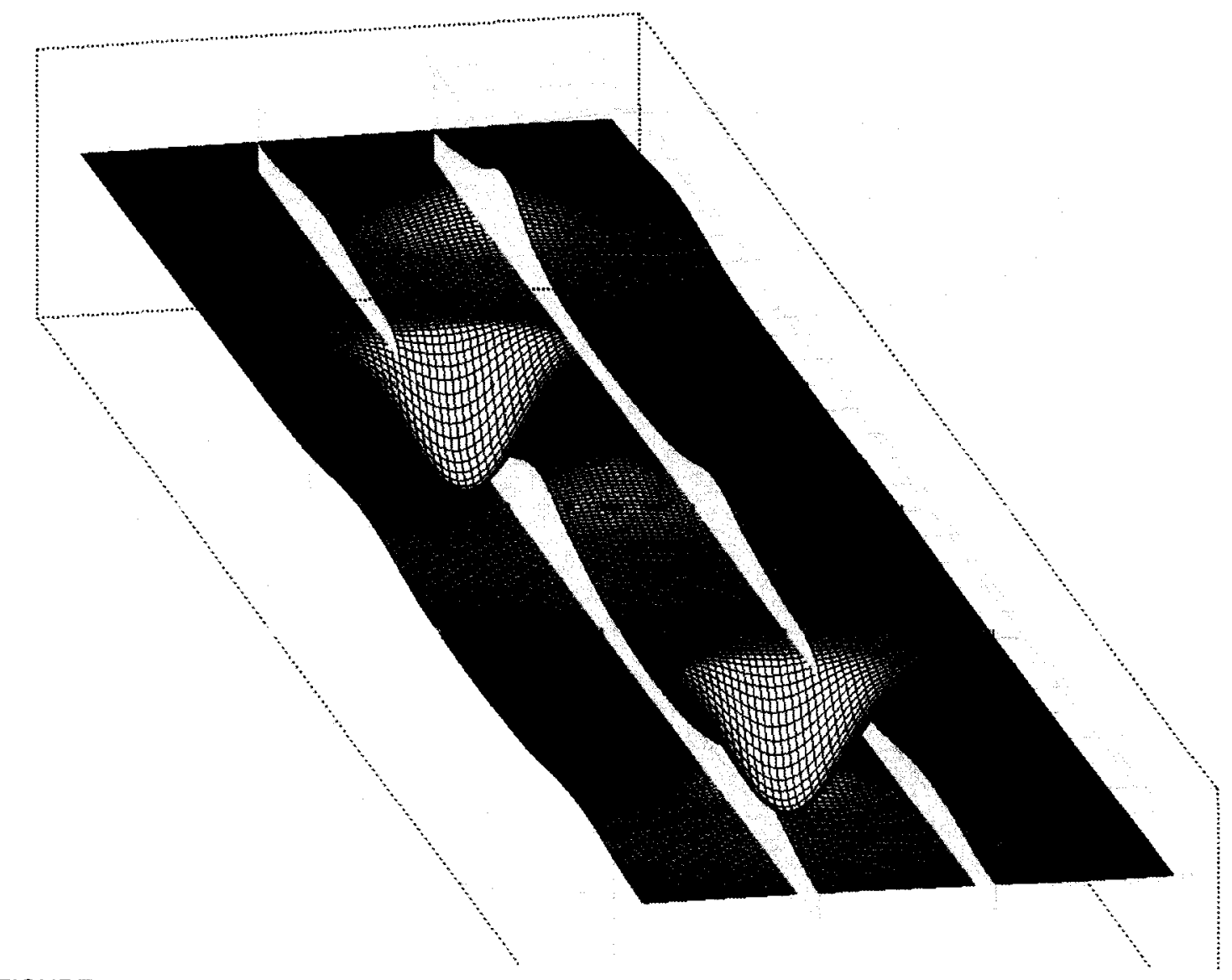

FIGURE 53. 


\section{PART 04 \\ Project Overview and Conclusions}

The shaping of space requires the organization of boundaries. 'Place' is typically understood through the inscribed perimeter of spatial limits. As a fundamental characteristic, boundaries provide a means of orientation, a denotation between inside and outside. Territorial borders exist as a mechanism of sovereignty through which authority of space is enforced. In the modern context of geo-political boundaries, the borderline is a contiguous threshold between neighboring nations. As an interface of cultures, societies, economies, religion, and tradition, border territories can evolve as spaces for cooperative or hostile relationships.

In the global age, the borderline is responsible for the management of two key roles. First, as the threshold between economic and social communities, the border must facilitate the incoming and departing movement of passengers and cargo. Secondly, the territorial integrity of nation-state demands the enforcement of border space as a fortified and surveilled edge. Consequently, the borderline represents an area of heightened intensity. The port of entry, however, is a condensed, congested opening through which a growing population is attempting to squeeze. As a result, the borderline can be more aptly described as a borderspace, a territory between territories. This ' $3{ }^{\text {rd ' }}$ space is an area outside the precise definition of sovereignty. Characterized by qualities of processing and transition, it can be found at every port of entry and - most significantly - within the constructed limits of the international airports.

This research has identified the interstitial territory of the $3^{\text {rd }}$ space as a site for architectural exploration. As initially argued, the growing magnitude of this space merits the consideration for its development. With the objective to postulate the architecture of the $3^{\text {rd }}$ space, the paper has worked to answer two questions. The first is to examine the potential functioning of this territory. The second is to propose an appropriate architectural expression.

As a convergence between intersecting populations that range in ancestry, age, gender, religion, profession, experience and culture, the airport exists as a unique building type. Within a transitory space, as Victor Turner has written, individual shed signs of hierarchy. As such, the airport can be a described as a territory of commonality, a non-nation space that is unbiased in its inclusion of every user. The value of this phenomenon, however, is not utilized within conventional terminal design. The proposal to integrate a mixed-use facility incorporating conference centre, leisure amenities and cultural space - is created to instigate the territory of airport space as a 'place' of commingling and exchange. Through this provision, the $3^{\text {rd }}$ space may exist as an ideal venue outside explicit boundaries of political ethnic and geographic definition.

Like transitory periods described by Turner, the architectural expression is driven through a desire to shed signs of hierarchy. Through the process that detaches explicit influence of external style, representation and form the architecture achieves a dimension of commonality. The derivation of architecture is approached through a process-based investigation. Aspects of internal experience provide operative parameters. Ultimately, the final design solution follows a hybrid framework integrating 'Generative', 'Fabrication' and 'Testing' processes. Through this strategy the architecture exists as a representation of itself, and is "of its own values".

The final interpretation of the design may be described in terms of interconnection and hybridized processes. The mixed-use facility, perched above the terminal concourse, incorporates a fluid undercarriage that is draped over spaces of terminal operations. Zones of 
'smooth' space offer informal spaces of interaction and intersection. The undercarriage and terminal concourse appear in tandem, a parallel expression of undulation and opening.

Functions are provided with loose physical boundaries through which multiple uses may occur. Compartmentalized functions remain visible through apertures and light wells. Zones of 'striated' space offer distinative operations. The undercarriage and terminal concourse intersect to reveal points of entry to above functions and provide visible opening to internal operations. Distinct, dedicated functions provide facilities for performances, conference and exhibitions. With a range of spatial experience and internal functions, the architecture is a varied container. Within a singular envelope, points of intensity mark moment of interruption and intersection while expansive spaces allow for orientation and cross programming.

The architecture of international space connects users. Within the containment of the $3^{\text {rd }}$ space, function is transformed from transitory to terminal. Inhabiting the in-between territory, the international space is able to coalesce users through a diversification of program. The appropriate architectural expression evolves from a process that integrates generative, fabrication and testing processes. Within the network infrastructure which it operates, the architectural of international space achieves an autonomous identify, a point of intensity along the vectorized paths of global movement. 


\section{BIBUOGRAPHY}

\section{MONOGRAPHS}

Adams, Nicholas. Skidmore Owings \& Merrill. SOM since 1936. Milan: Electa architecture, 2007.

Agamben, Giorgio. Means without End. Trans. V. Binetti \& C. Casarino. Minneapolis, University of Minnesota Press, 2000.

Augé, Marc. Non-Places: Introduction to an Anthropology of Supermodernity. Trans. John Howe. New York: Verso Publishers, 1995.

Blankenship, Edward G. The Airport: Architecture, Urban Integration. Ecological Problems. London: Pall Mall Press, 1974.

Blow, Christopher. Airport Terminals. Oxford: Butterworth-Heinemann, 1991.

Deleuze, Gilles, and Félix Guattarr. A Thousand Plateaus. Trans. Brian Massumi. Minneapolis: University of Minnesota Press, 1987.

Foreign Office Architects. The Yokohama Project. Barcelona: Actar, 2002.

Frank, Suzanne. Peter Eisenman's House VI: The Client's Response. New York: Whitney Library of Design, 1994.

Fukuyama, Francis. The End of History and the Last Man. New York: The Free Press, 1992.

Fuller, Gillian and Ross Harley, Aviopolis: A Book About Airports. London: Black Dog

Publishing LTD., 2004.

Galofaro, Luca. Digital Eisenman: An Office of the Electronic Era. Trans. Lucinda Byatt. Basel: Birkhauser, 1999.

Gennep, Arnold Van. The Rites of Passage. Trans. Monika B. Vizedom and Gabrielle L. Caffee, Chicago: University of Chicago Press, 1960.

Gordon, Alastair. Naked Airport: A Cultural History of the Worlds Most Revolutionary Structure. New York: Metropolitan Books, 2004.

Greater Toronto Airports Authority. (GTAA) Celebrating Success: GTAA 10 Year Anniversary. Toronto: 2006.

Greater Toronto Airports Authority. (GTAA) Taking Flight: The Airport Master Plan 2008-2030. Toronto: Grafikom, 2007.

Lefebvre, Henri. The Production of Space. Trans. Donald Nicholson-Smith. Massachusetts: Blackwell Publishers Inc., 1992.

Massumi, Brian. Parables for the Virtual: Movement. Affect. Sensation. Durham: Duke University Press, 2002.

Roach, Kent. September 11: Consequences for Canada. Montreal: McGill-Queen's University Press, 2003.

Romero/LAR, Fernando. Hyberborder. New York: Princeton Architectural Press, 2008.

Tschumi, Bernard. Event-Cities: Praxis. Massachusetts: The MIT press, 1994.

Turner, Victor. The Forest of Symbols: Aspects of Ndembu Ritual. New York: Cornell University Press, 1967. 


\section{EXHIBITION CATALOGUE}

Rosler, Martha. In the Place of the Public: Observations of a Frequent Flyer. Ostfildern-Ruit: Cantz Verlag, 1998.

\section{PERIODICALS / JOURNALS / ESSAYS}

Eisenman, Peter. "The End of the Classical: The End of the Beginning, the End of the End," Perspecta 21 (1984): 154-173.

Elden, Stuart. "Territorial Integrity and the War on Terror," Environment and Planning A 37 (2005): 2083-2104.

Foreign Office Architects, "The Yokohama International Port Terminal," El Croquis 115/116[1] (2003): 35-50.

Foucault, Michel. "Of Other Spaces," ms. Diacritics Trans. Jay Miskowiec. 16 (1986) 22-27.

Gandelsonas, Mario. Introduction, "From Structure to Subject: The Formation of an Architectural Language" House X. By Peter Eisenman. New York: Rizzoli, 1982: 7-30.

Guattari, Felix. "Movement: Life in the Air Changes Everything on the Ground ." Aviopolis: A Book About Airports. By Gillian Fuller, Ross Harley. London: Black Dog Publishing LTD., 2004.

Wark, McKenzie. Essay. "Telegram from Nowhere". Mutations. By Rem Koolhaas, et al. New York: Actar, 2001. 30-40.

Williams, John. "Territorial Borders, International Ethics and Geography: Do Good Fences Still Make Good Neighbours?" Geopolitics 8(2). 2003. 25-46.

\section{ELECTRONIC SOURCES}

2007 World Airport Traffic Report. 2007. Airports Council International. 28 Oct. 2008. $<$ http://www.airports.org>

Canada's Privacy Statement. Canadian Border Services Agency. 30 October 2008. <http://www.cbsa-asfc.gc.ca /prog/nexus/privacy-privee-eng.html>.

Canadian Air Transport Security Authority. 28 October 2008. <http://www.catsaacsta.gc.ca>

National Airport Policy. Transport Canada. 20 October 2008.

<www.tc.gc.ca/programs/airports/policys

Rapid Transit Access to Lester B. Pearson International Airport: Final Report. IBI Group.

February 1999. Transport Canada. 20 June 2008. <http://www.georgetownpearsonstudy.ca>

\section{NONPRINT SOURCES}

Fortier, Renald. Curator: Aviation History, Canadian Aviation Museum. Interview by Author, 07 November 2007.

Gooch, Daniel-Robert. Director of Communications: Canadian Airports Council. Interview by Author. 31 October 2007. 
Jensen, David. Partner and Joint Venture Representative: Adamson Associate Architects. Interview by Author, 13 February 2008.

King, Peter. Chaplain: Fellowship Chaplaincy Services, Pearson International Airport. Interview by Author, 10 February 2008.

Petrie, Lee. Manager: Cultural Programming, Greater Toronto Airport Authority. Interview by Author, 24 October 2007.

Shaw, Steve. Vice-President Marketing and Business Development: Greater Toronto Airport Authority. Interview by Author. 22 October 2007.

\section{FILMS}

Eames, Charles and Ray. "Expanding Airport" The Films of Charles \& Ray Eames 19071978. Vol. 5. Santa Monica, Pyramid Films and Video. July, 1998.

The Terminal. Dir. Steven Spielberg. Perf. Tom Hanks, Catherine Zeta-Jones. Dream Works Pictures, 2004. 


\section{APPENDIX 01.}

Interviews. 


\section{NAME \\ POSITION}

DATE

INTRODUCTION

WHAT IS AN
AIRPORT?

WHEN YOU TRAVEL, WHEN DO YOU KNOW YOU ARE HOME?

\section{OVERVIEW}

SEAN: When does your job begin to affect the passenger experience?

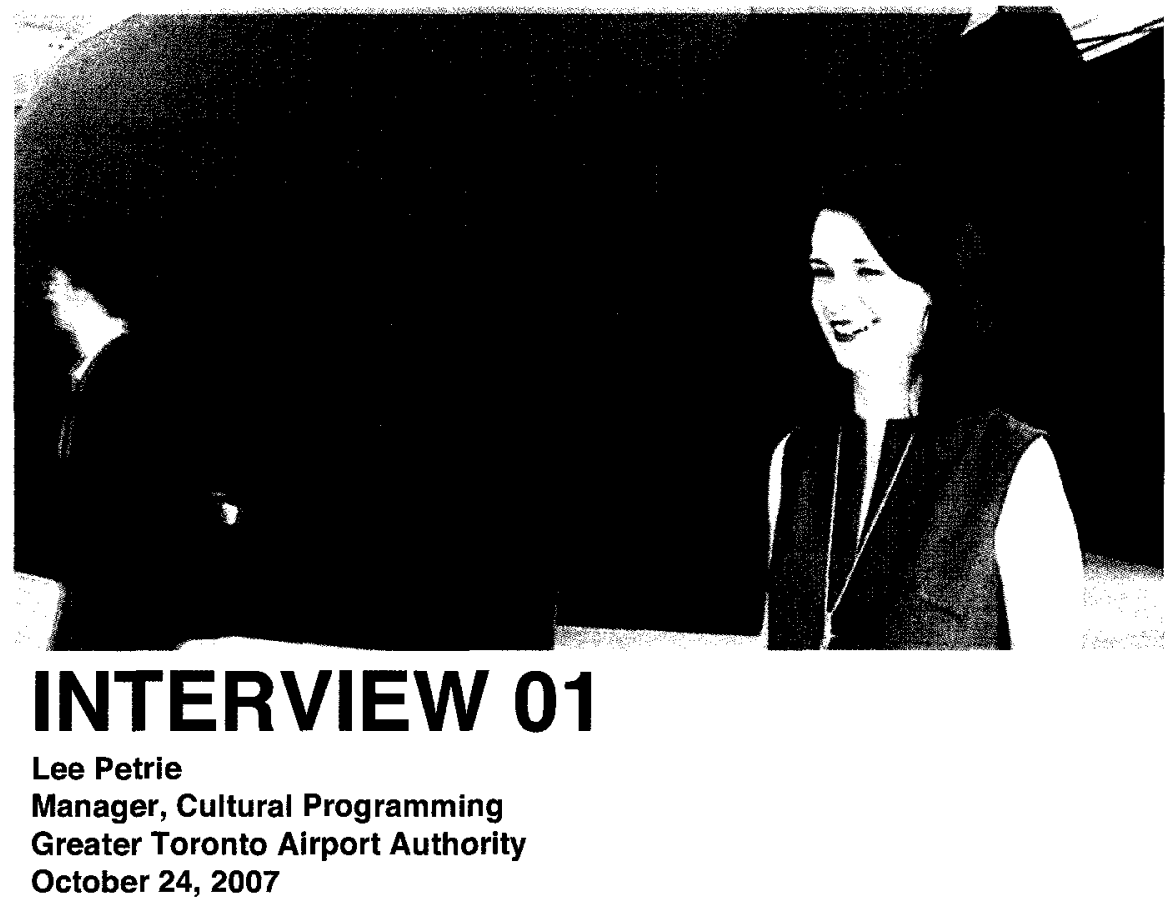

My name Lee Petrie. I am the manager of Cultural Programs for the Greater Toronto Airports Authority. My job is to be the curator of the airports changing exhibition spaces and our permanent collection of sitespecific works.

It is a place for people to catch a plane. It's a transportation hub but it's also a lot more than that.

We're living in an age of heightened security when people are spending more and more time within an airport not necessarily because they want to but because they have to. So airports are becoming more than just places to catch your plane. They're becoming retail environments and they're becoming cultural environments. And I think we are seeing a great shift in the way we think about culture and present culture to people. We are moving beyond institutions. Especially in a city of Toronto we are seeing a huge investment in cultural infrastructure we are also seeing culture presented in non-traditional spaces. We are tying into that. Put art in places where people are going to see it.

When I get off the plane and step in to the airport. For me, that's the place where I am already comfortable. It's when I'm on Canadian soil.

My only wish is for the gallery to be post security. It would be nice for people to visit a gallery while they wait for their plane. My preference would have been to have our substantial walk-in gallery space to be postsecurity.

We've tried to make a statement about the city with this airport but we've done it in a less obvious way. We've tried to make a statement about what the city and surroundings are all about by saying Toronto is a great cosmopolitan. We're multi-cultural. So the art work we've chosen reflects not only multi-generational Canadians but we also have international artist here. I think that makes a strong statement about the city.

It's more focused on the outbound. The art more directly touches departing passengers and is mainly sited within the departure lounges. 
SEAN: What is your mandate?

SEAN: As a curator, how do you respond to that kind of censorship?

SEAN: What is the role of art in the airport?

SEAN: Do you find yourself fighting battles to make a place for art in the building?

SEAN: Is it possible for you to propose new spaces for art in the terminal?
I have no particular mandate for with respect to each exhibition space. I am very fortunate to be working in a situation where the mandate is incredibly broad. I can show art I can show science, craft, design, architecture, history, technology, and nature. My mandate is better to describe in terms of what I can't show. I can't show anything that will cause any anxiety for travelers. I can't show any work with overly political messages or depictions of violence. I can't have any material that has representation of a weapon. That kind of stuff simply won't fly.

I don't find that difficult to deal with. I think that's a very modest restriction. I think there will be other opportunities in my career to do that. It doesn't mean that we can't do challenging content it just means we have to be aware of who are audience is. Myself, as a passenger, when I come to the airport do I want to see something about the great air disasters of history? No, not really. That's going to stress me out. So, no. I don't find that constricting to deal with.

As a curator and working with artists, our objectives are to get things out to the people. It's not simple about us and our ideas. It's about enriching other people's lives. So if we have to edit out a couple aspects of the million things that could be shown, I don't find that problematic.

Art serves a number of different purposes in the airport. Our primary objective with the program is to give people a moment of relaxation. We recognize that even in the best designed airports, people are anxious when they travel.

"Where's my gate?"

"Are there going to be any complications?"

There is a lot associated with travel that causes a lot of people anxiety. We felt it was important to get people to decompress, to allow them to put their mind in a different place. We also recognize that people are stuck in the airport for longer and longer because of increased security measures. So allowing people to learn a bit, to educate themselves, to get a flavor of the local culture was also important to us.

I'm the first person to enjoy shopping, but there is only so much retail you can do. So, it's nice to have kind of intergenerational opportunity for parents and children to spend some quality time with each other.

I wouldn't say I'm fighting a lot of battles to make a place for art because, as we discussed before, spaces were designated in the terminal to be art spaces and that's a terrific situation for me to be in. I like to think that we have a good relationship with that department so that if I want to do a project that is not in one of my designated spaces I can go to my colleagues in that department and say "are you okay with me using this space temporarily"....

In the same way, they come to us. If for example their putting a car in terminal, they would come to us and say: "this is the kind of proximity that we are dealing with. Are you ok with that?"

So, its really important to have that kind of communication.

I would say the pressure I'm under now is for me to create a no cost situation. Not that I will not be paying artist fees or design fees, but can I get sponsors for the exhibition so that I can offset my program costs. And that is the situation that all of us at the GTAA are dealing with. How can we cut costs and how can we make more money?

That would be hard to accomplish since the spaces for art have already been allocated. 
SEAN: Is it a primary interest for the art and architecture to speak of gateway? Or

Canada?

FINAL COMMENT
I think our vision for the program is for it to say something about the city and about the country.

And to send out a very positive message.

Maybe I can throw in a quick comment here.

I love the international departures area because they took a different approach in the artwork. They wanted this to be something interactive and hands on and we don't see that with the works in the other sections. For this section, they really wanted works with which people could interact. It's more than just a visual experience. And we see that with the Serra. I think that's a really successful part of this area.

END OF INTERVIEW 


\section{NAME \\ POSITION}

DATE

INTRODUCTION

WHAT IS AN

AIRPORT?

\section{WHEN YOU TRAVEL, WHEN DO YOU KNOW YOU ARE HOME?}

SEAN: Any unique stories you might be able to share about your experiences here?

SEAN: Have you found any unique challenges to your job

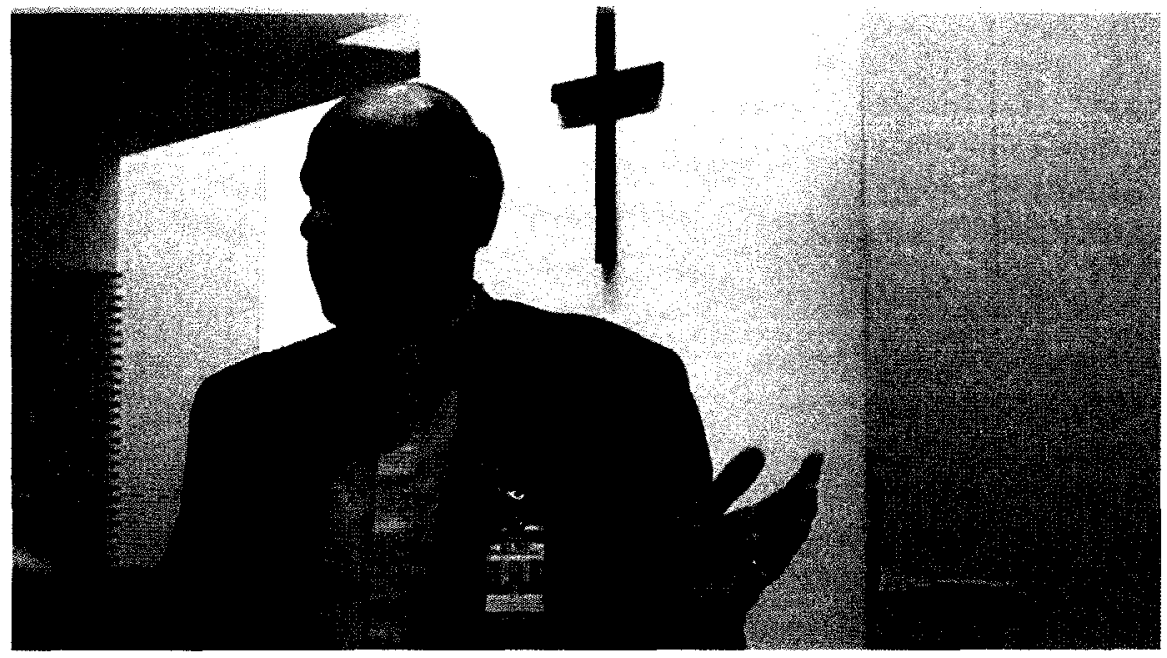

\section{INTERVIEW 02}

\section{Peter King}

Fellowship Chaplaincy Services

Pearson International Airport

February 10, 2008

My name is Peter King and I serve as a evangelical chaplain at Pearson airport. I have been serving here since January of 2000 . Prior to being a chaplain I worked for Air Canada for 26 years. There are three serving on the Roman Catholic team.

What is an airport to me?

An airport is really my sphere of ministry, a place where passengers and employees interact.

Passengers are flying and employees are serving them. We are the spiritual caregivers for both those groups.

Well, I think any Air Canada air plane is home.

When you see the aircraft.

Sure. Just last Wednesday I received a call from an air Canada ticket agent just letting me know that a young women who had purchased a ticket for thunder bay to see her two young children who were involved in a car accident. I asked the agent what gate she was at. She said gate 112. I said l'd be there. Just prior to meeting the passenger, I called a church - sometimes I do that. I call an outside church that I'm connected with and ask the pastor to pray for this particular situation. When I got to the gate, I spoke with the agent and asked if she could page the passenger. I stayed at the counter and saw this petit lady get up and walk toward me. When she saw my collar, she broke down and started to cry. I put my arms around her and said l'm so sorry. I said to her, I want you to know that I called a church and asked them to pray for you. I mentioned the name of the church. Incredibly, this lady attends a bible study at the church on Wednesdays. She was so comforted to know that that church was asked to pray for her.

We have a number of those types of situations that occur everyday. I call that divine appointment.

The skill set required for this position is quite comprehensive. You have to be able to relate to people at all levels. I could be talking to a VP one 
by virtue of being in an airport?

SEAN: What your approach to your ministry in the airport?

\author{
SEAN: Do find people \\ approach you from time to \\ time?
}

SEAN: Have you developed a sense of when people need to be approached?

SEAN: What is it about air travel that excites you so much?

SEAN: Do you feel the airport has done enough to make this resource available, known to passengers? moment and a baggage handler the next moment. I've got to understand where they're coming from and their work environment. So, it's very very unique. It's not simply like being in a church and talking to that person within the walls of that church. It's being in their setting.

Pearson Airport is a global village. It a global village with people from every nation, every background, every language, every culture, every need.

I would say we are involved in a frontline ministry.

I often go walk around. I try to do it systematically. So it's not necessarily random. One day I go to pier $\mathrm{D}$, one day Pier $\mathrm{E}$, one day I go down to the baggage area, one day to the customs hall. We try to hit various departments.

Oh, absolutely. Or I approach them.

Oh, sure.

You can't always recognize it on the surface.

Sometimes the people who appear to be the happiest, have very deep needs. You would never know. But as you get talking to them, they begin to open up to you.

In an airport, you can have a lot of people around you but you can be very lonely. Loneliness is not something that's contingent on the number of people around you but it's the quality of relationships that are meaningful.

An airport is an exciting place. For those who understand an airport and how it operates and all that goes into getting an airplane off the ground, it's absolutely amazing. You've got many departments working to get an airplane off the ground. It's amazing to see how it works.

\section{ST.OCC center}

Station Operation control Centre.

Yeah. That's a really good question.

We appreciate what the airport has done.

We appreciate the space that they have given to us here. It would have been nice to have this space on the departures level. Because that is where people are leaving from.

From my perspective I am just thankful to have the space that we've got.

\section{END OF INTERVIEW}




\section{NAME \\ POSITION}

DATE

INTRODUCTION

WHAT IS THE CAC?

WHAT IS AN

AIRPORT?

\section{WHEN YOU TRAVEL, WHEN DO YOU KNOW YOU ARE HOME?}

SEAN: Could you speak to the magnitude, nature of cargo and passengers across Canadian borders and their change in recent times?
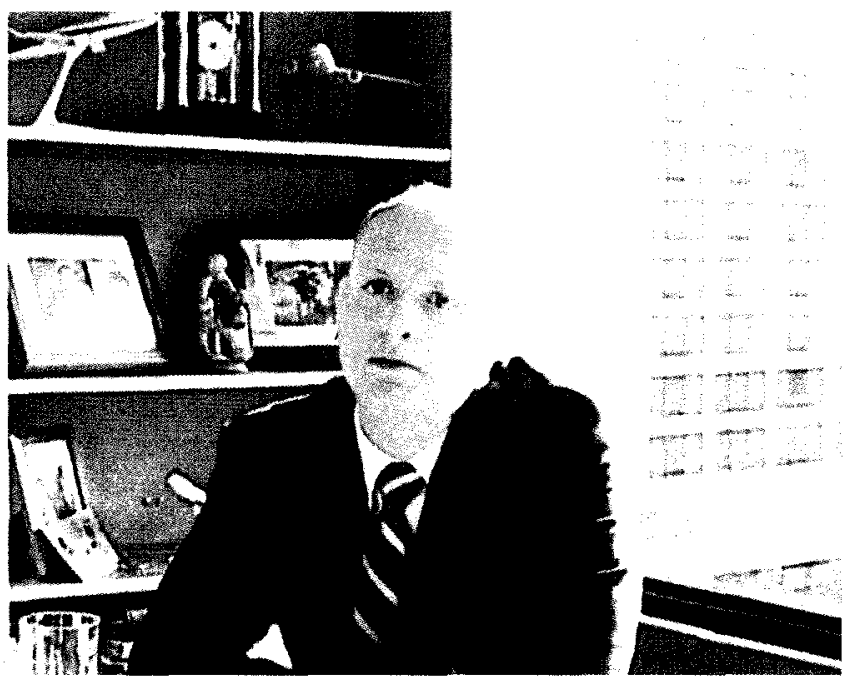

\section{INTERVIEW 03}

\author{
Daniel-Robert Gooch \\ Director of Communications \\ Canadian Airports Council \\ October 31, 2007
}

My name is Daniel-Robert Gooch

I am director of communications for the Canadian Airports Council. I manage everything related with communications both external and internal.

I do press communications and speeches for the CAC and work on research for position papers.

The Canadian Airports Council is the voice of Canada's airports. We have 47 members representing 181 airports across the country. Our members extend from the smallest to the largest airports. Canada has 27 Airports designated as National Airport Systems. (NAS) the national government retained ownership of property but devolved control of them through lease agreements.

Well, a lot of people think of an airport as the terminal building. They are much more than a terminal building. You can look at it in many different ways. In the strictest definition, it is the territory within the perimeter airport property, which includes the terminal building, the fixed base operations, hotels, office building. It's really like a city in many ways. But really, we see airports as gateways to the communities in which they serve. For some of our smaller members, airports can really be vital lifelines to the outside community. But even in larger cities, the airport is still an important gateway for trade and tourism. Approximately, 100 million passengers travel through Canadian airports every year. So we really see airports as vital gateways. Economic, trade and social gateways to communities which they serve.

I consider myself home when the aircraft lands.

When we look at growth in the past 10 years, it's been phenomenal. I believe we're talking about 50\% growth. Since 1991, Canada has experienced more than a $50 \%$ growth in domestic passenger traffic and $120 \%$ growth in international traffic. The $120 \%$ is also growth overseas, not just to the U.S. There has been growth in the transborder market as well, but it has been outpaced by the overseas growth. We have seen a lot of changes in policy since 1991 which has enabled this to happen. The 
SEAN: How would you characterize World Incidents, infectious diseases, acts of terrorism

and their effects on aviation industry?
SEAN: What kind of dialogue is happening now between airports and the federal government? national airports policy is one of the biggest. Which was what lead to the devolution of control of airports from the federal government to not-forprofit local operating authorities. In 1991, the federal government were subsidizing airports to the tune of 100 million dollars a year. By devolving control, the airport authorities were able to upgrade their facilities to get them to be able to take advantage of the growth opportunities. By the end of government ownership, airports were bursting at the seams with crumbling infrastructure. Which is why Canadian airports have invested more than 9.5 billion dollars in capital investments in the last 15 years.

A blip is how I would characterize those.

For an airline from any one country to serve another country, there has to be an air service agreement between the two. Those agreements have dictated everything from the size of the aircraft to the total capacity of the number of seats per week, the frequency per week, the type of carrier, what destinations they can serve, whether they could continue to other countries. It was very prescribed. In the early 90's that started to change. The U.S. adopted a policy of OPEN SKIES. Airlines from two given countries could serve any point within the two countries. There would be no restrictions on frequency, no restriction on capacity, or pricing. This has become the standard in air service agreements since the early to mid nineties and we're seeing more linearization. Canada had an open sky relationship with the United States by 2005 . Canada has new agreements with china, India, United Kingdom, Ireland, Iceland, new Zealand.

The rules of the sky are governed by what are called first thru 7 freedoms. The first 4 are pretty easily to get. They include fly-over, direct service. They are pretty standard.

$5^{\text {th }}$ Freedom: U.S. carrier to Egypt than on to third location $6^{\text {th }}$ Freedom: Similar

$7^{\text {th }}$ Freedom: foreign service by a foreign carrier. U.S. carrier doing service from Canada to UK for instance.

Cabotage: domestic service within country by foreign carrier.

Probably the biggest issue facing Canadian airports today is competitiveness. Particularly since the parity with the U.S. dollar, Canadian businesses have competitiveness issues. In the airport context, this primarily relates to the burden placed on airports and their passengers through taxes. The most high profile issue for us is the issue of airport rent. The CAC's stance is that the rent burden should be lowered or eliminated. Ideally eliminated. Which would enable savings to be transferred to air carriers and their passengers.

One of the biggest issues of airports worldwide is capacity and congestion. Air travel is growing. Its growing in Canada. Its growing out of Canada. Its growing internationally. And a lot of airports are busting at the seams. They have congestion issues. They have terminal congestion issues. They have property congestion issues. So, the unique business model in Canada has been with the devolution of government ownership to the airport authorities. It allowed for enough flexibility to invest such amounts in capital investments.

We estimate that at least 2 million passengers per year are being leaked to U.S. border airports.

Canada processed about 1.4 million tons of air cargo in 2006 
NAME
POSITION

DATE

INTRODUCTION

WHAT IS AN

AIRPORT?

WHEN YOU TRAVEL, WHEN DO YOU KNOW YOU ARE HOME?

\section{OVERVIEW}

TIME 1:17



INTERVIEW 04

Steve Shaw

Vice-President

Marketing and Business Development

Greater Toronto Airport Authority

October 22, 2007

My name is Steve Shaw. I am currently Vice-president for Marketing and Business Development for the GTAA. Part of my role is dealing with how the airport relates to the outside world. The GTAA is an airport operator. It manages it to provide global access to the GTA and to do so in a competitive and sustainable manner.

An airport is an intermodal space. It's a transfer space. It facilitates the movement of passengers and cargo.

As soon as I pass through customs.

The greater growth in traffic is connecting traffic.

We find Toronto is an excellent place for people to land and then go to the states, or land here and go to South America....or Israel - very popular.

We talk about a gateway but it is also a functional gateway. And the function has to relate to the way people come in and go out. There's security, there's customs, there's immigration, there's baggage and the movement within a 3 sector airport. (International, transborder and domestic)

They each has separate security requirement and separate processing requirements.

We have a complex airport.

A person coming in international can come in, and rather than going through Canada Customs, they can go through what we call the in-transit pre-clearance. And once you are past customs, which is a pre-clearance function here, you're virtually in the states. The gateway is into North American, its into Canada, its into Ontario and its into Toronto.

What we've got to do is help people understand that when do transit, as in they arrive internationally and depart internationally, they are still in Canada. We want to make sure they still have a Toronto experience. [pause] Somewhat. And we do that through the retailing. 
SEAN: What is that inbetween space after the aircraft and before customs?

TIME 6:15

SEAN: So from that perspective it's in everyone's best interest to minimize that distance.

SEAN: How can airports get away form the sameness of airport design? How does the GTAA approach this issue?

TIME 8:25

TIME 11:40

SEAN: How doe the airport approach sustainability in the airport?

TIME 06:23
It's a very sterile space, very secure space. You've got to be very careful of that space. In some ways it is a transit space. You've landed but you've not entered the country. You don't enter the country until you've gone through customs. It's a processing space. It's a secure space. And it can't be too Canada.

One of our challenges is to make that space more animated. One ways we may do that is through advertising, which may be of a local flavor.

When you exit the aircraft, the first person you are supposed to see is the customs officer. We have a lot of debate about arrival-duty free. We think people who get off the aircraft, would like to buy something. This is happening at a lot of airports. So, we're into the discussion with government on that. There are a few problems with that. But the thinking is that if you are coming into Canada, you've got to come through the primary inspection line.

Certainly

I think we have not solved that exactly.

You start first by recognizing that there is in international signage.

You do need the international signage. And people need it. You need the signage. There is nothing worse than a space where you don't know where to go next. It's very important for peoples comfort.

Secondly, there are common functions. Where's the rental cars? Where's the baggage? So, you need that basic commonality

The airline wants to come and find a certain commonness. The gates got to work in the same way as it did when it left.

What we've tried to do is accept the gate but then create a terminal that helps people relax. You've been in the plane a long time so you come off and you want space and you want light. And that is the fundamentals to the architectural design. And secondly, we want them to do able to see where they are going. The value of what we've done, I think, is that you can see where you're going. The architecture helps you to know where you are. And we find, and people have said this, that this is a comfort to them. That doesn't speak to Toronto, but it does speak to a functionality that is needed.

Strategic Plan

1. Gateway Development

2. Sustainability

3. Cost

The Aviation Industry uses fuel. And fuel, at the moment, certainly creates green house gas emission. Fuel by its nature, being liquid, can be stored on an aircraft in a very efficient way. We argue, very much, that there is other ways society can address global green house gas emissions. Aircrafts make up less than $8 \%$ of total contributions. They are tremendously important to the welfare and economy of the globe. And whether we like it or not, air travel is fundamental to our [financial] sustainability. We want to be efficient. We want to be responsive. We are working with the airlines and we are pushing between sound mitigation, and better fuel efficiently. And the airlines are going that way.

Runway configuration. Taxiway configuration and high speed taxiways. If you can land an aircraft, you can get it off quickly. 
Our airside capacity is about 130 movements per hour.

SEAN: Who are the different bodies in the airport to control Jurisdiction?

TIME 08:21

SEAN: Are there future plans for Pickering lands?

\author{
SEAN: Original plans to \\ demolish terminal 3 . Still \\ happening?
}

SEAN: Aircraft as vessels as international territory. How is leased space controlled / delegated?

TIME 14:00

SEAN: Other city's have downtown areas for remote check-in. Is Toronto considering that?

SEAN: What is the general attitude of people intermingling of people within the terminal?

TIME 17:30

SEAN: Looking back retrospectively, are there any things you wish you had done differently?

SEAN: I feel as though art work brings color to the terminal.

SEAN: Can you give me some
Transport Canada is the landlord of the airport but we are the tenants and we sub-lease to the airlines. We are required to coordinate all the functions within the terminal. We are required to provide space free to the government agencies. We provide it and we coordinate it. We provide the space and build it to their specification.

Demands and issues of building a Second airport.

We've built an airport we can expand. We now have a terminal design that can be expanded as one terminal or we can maintain 2. So the option is there.

We control the apron. Gate allocation is our responsibility. We own all the gates. We are a common use airport. What happens is that we have an operating agreement that will offer preferential use of a gate to an airline. So, the value of common use is that we provide the terminals: the gates, the check-in counters and the computers. So a flight can be Air Canada this hour or United the next hour and the equipment's common. And that is a very big asset. Airlines complimented us for this. They come in and it's literally plug and play.

Yes. Oh yes, we are very open to that. You can check-in at home. So, what is check-in and what isn't? That is a question of where you're transiting. Check-in counters are in rapid decline. We now have kiosks. And once you have kiosk the questions becomes: why you can't have it someplace else?

We are working with the government, and we've been arguing for a long time for what we call co-mingling which is arriving passengers coming into a sterile, secure area. And what's the problem with having them mix with people going out? You do it domestically. A lot of airports around the world do that now. But there are security, and legislative restraints. So we have to work and that is a process in place. But obviously, to be able to come in walk past shops is much better than coming in and going on a catwalk which is what you do now: Sterile in the corridor, don't look at anyone, don't touch anyone.

Aircrafts are an incredible complicated piece of machinery and it speaks to what it does. Security is such that it is simply gone.

In my present role in marketing, I wish we had more space for retail. And shaped it more in terms of helping people relax and spend money. I think we were very focused, at the time, in putting emphasis in operational efficiencies and architectural cleanliness. The architects had much to much say in the terminal.

You take the Richard Serra sculpture. You're not able to put anything next to it. That is a very valuable retail space. If you go to Vancouver, that space is retail focused. That space is entirely retail. You may not like that as an architect, but for me trying to make money, that is a great thing. Advertising makes money but it also adds something. The positive thing is that it fits in. It adds something. People like it.

I always argue that people bring colour.

Contingent from peel police. We have Airside safety officers. Airport 
insight into some of the operational complexities managed by the GTAA?

TIME 30:00

SEAN: Could you explain the control of aircrafts by control towers?

SEAN: How many people work at the Airport?

TIME 34:00

SEAN: I suppose on of the disparaging part of airports is in their social categorizations. Classes and categorized lines.

TIME 36:00

SEAN: new security Biometrics. Does GTAA plan to integrate that?

TIME 37:00

SEAN: New seat design has really changed social environments for travel. They speak less about companionship.
Operations control centre. We have a logistics Centre, An IT help centre. Apron control Unit. We also have a baggage supervision unit. There is a peel police unit. There are a lot of people who work with us and for us. Really it's like a city. We don't produce food but just about everything else. We have sewer systems, water retention systems, and a co-generation plant. We have a central utilities plant. We have groundside. We have a 20 bus ground side fleet.

Apron control: allocates gates and Manages and marshals the aircraft from a point on the taxiway and over to the gate.

Somewhere in the line of 55,000 . It's a city in-itself.

One of the arguments that the airlines make is that you treat ever passenger the same. They ask for giving priority to our business class passengers and give them a bit of speed. The answer is we don't. Now, there may be a business to be made by doing that. And we are looking at that but at the moment we don't. Once you get to security, it's the same line.

We have that here now. In fact, in my pass there is a chip. And that has my retina and my fingerprint. To go through security, I use this and it will validate me through my retina.

...And that's sort of the fun thing. It's the commingling. You meet an interesting person.... and I like that....I think that is part of the travel experience. You do rub shoulder with other people. I wouldn't want to be too separated from that.

END OF INTERVIEW 


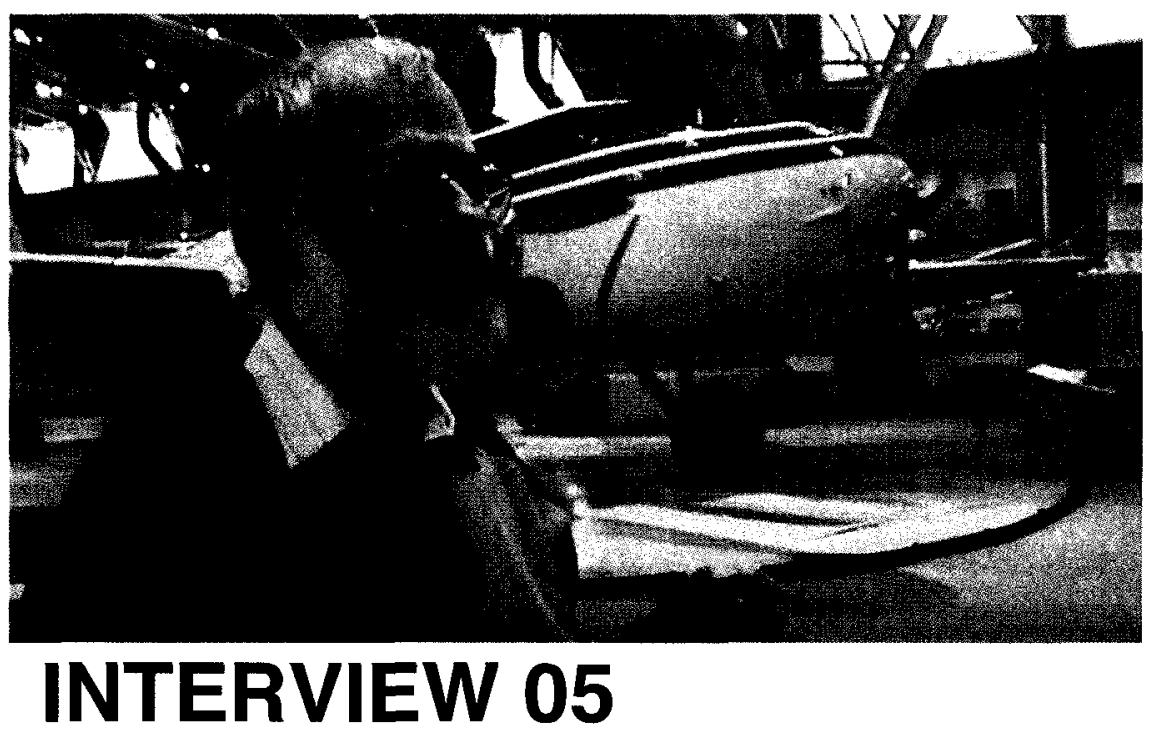

\section{NAME \\ POSITION}

DATE

INTRODUCTION

WHAT IS AN

AIRPORT?

\section{WHEN YOU TRAVEL, WHEN DO YOU KNOW YOU ARE HOME?}

SEAN: What can you tell me about commercial aviation in Canada?

\author{
Renald Fortier \\ Curator, Aviation History \\ Canadian Aviation Museum \\ November 07, 2007
}

My name is Renald Fortier.

I am the curator of aviation history at the Canada Aviation Museum in Ottawa, one of the national museums in Canada. We are part of the Canada Science and Technology Corporation. The Canadian Agriculture Museum, The Aviation Museum, and The Science and Technology Museum make up the corporation.

An Airport, by in large, is a bit like a train station or bus station. It has become that. In early days it may have been a point of departure a bit like a harbor of a large city.

To board a ship that would cross the Atlantic: it was a glamorous thing! You were dressed in your best clothing. You had to be well off. In a way, the airplane was like that. Whereas, nowadays you have people in sandals and shorts going to Florida in the same way they would take the car or bus. The airport in a way has become that. Which is a good thing! It has now become a form of mass transportation.

Although, it is quite different in the sense that you don't have any control.

I don't like flying. I'm not afraid of flying. I don't mind it. I just don't like the idea of being searched and treated like a mass murderer. It's not a pleasant experience. Breathing recycled air and eating plastic food. I don't do it unless I have to do it. I'm home when I arrive at my apartment, open the door and lock it. I see my apartment and everything is still there.

It has a lot to do with geography. Canada is about the size of Europe, give or take a few hundred square kilometers. We have about 32 million people. I do believe Europe has somewhere between 6 and 7 hundred million people in the same territory. So if you want to go anywhere in Canada, it takes time. Airplanes became the way to cross the country. Regular flights began in the late 30 's with Trans Canada Airlines.

Canadian Pacific airways developed shortly after the Second World War. By and large they were two major national airlines. Air Canada (TCA) has been an international carrier since the Second World War. You had the technical developments. For example, you have the piston engine, cabin pressurization, the jet engine either in turbo prop, turbo jet or turbo fan. Then you have the jumbo jet. And all of that has an effect on tourism. 
SEAN: How did Jet power affect the aviation industry and intercontinental flights?
The first major airport, financed by the federal government that was not a military base was Saint Hubert near Montreal. One of the reasons for that was Britain's wishes or interest in creating an inter-imperial airship service. Great Britain to Canada. Great Britain to South Africa. Great Britain to India. There were these big routes under consideration. As part of that, Canada created saint Hubert. And created this $60 \mathrm{M}$ mooring tower. Only one ever arrived.

If you look at the first jet powered airline to go into service. The comet. You're looking at midish 50's. It was pressurized which was a bit of a novelty at the time. The comet had problems with pressurization and metal fatigue. Followed in the late fifties were the DC- 8 and the Boeing 707.

These aircrafts are the ones that truly commercialized inter-continental flight service.

END OF INTERVIEW 
NAME
POSITION

DATE

INTRODUCTION

ROLE AND

RESPONSIBILITIES

WHAT IS AN

AIRPORT?

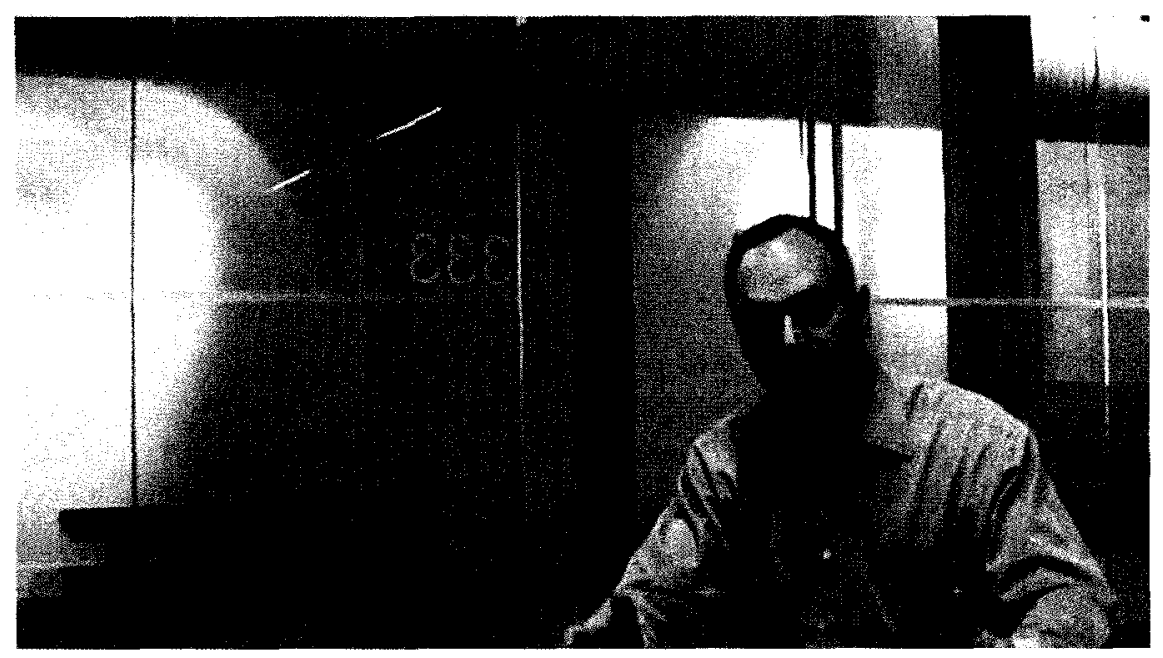

\section{INTERVIEW 06}

David Jensen

Partner and Joint Venture Representative

Adamson Associate Architects

February 13, 2008

I am David Jensen. I am a Partner at Adamson and I am part of a joint venture. With the airport there was a joint venture between Adamson, Safdie and SOM. Right. It was a three way. I'm also representative for the joint venture.

Ok. Basically, I was much more the upfront guy. I do a lot more work with master planning. Planning for the terminal. Adamson's role is actually much more project delivery. Putting together the contract documents and the various components. My strength personally was that I was involved in this master plan and in the previous master plan. So I came with a lot of history about how Toronto was organized and how the terminal was organized.

What is an airport.. Ok.

If, [pause] you know it. [pause] That be a really good question.

To me airports are [pause] They're definitely ports. That means they're entries and exists. They're gateways to cities. Now, [pause] you could [pause] They're not always gateways to countries because they're gateways to regions. Because of immigration laws you will actually have national components to large-scale airports. But lets say its really important. It's really and entrance. And it sort of replaces what an original sea-port was. It was a method of getting in and out of various locations. It meant, though, that you could build it anywhere. You didn't need to build it on the ocean or on a waterway. It drives the whole economy around it. I would say definitely it's a port of entry and exit.

An airport also must mitigate between two scales. One is the size of a 747 and the other is the size of a little tin car. And you're always shifting scales between mass-transit and independent. So, you're always seeing scale shifts on both sides. And one travels short distance and one travels long distance. I always thought terminal buildings were kind of unique in that they're basically circulation. They're a way 


WHEN YOU TRAVEL,
WHEN DO YOU KNOW
YOU ARE HOME? WHEN
DOES THE EXPERIENCE OF
ARRIVAL BEGIN FOR YOU?

DID YOU COME TO THE TABLE WITH A CERTAIN LEVEL OF EXPERTISE WITH RESPECT TO THIS BUILDING TYPE? to of getting from a car to a plane or from a plane to a car. You could say train. Same thing, right. Lets say the majority of facilities are circulation just so you can actually navigate between the two. A transfer point.

Ah, The problem [pause] OK [pause] Let's see. It's not a problem. Lets say you break your terminals down. What Toronto is is a very large originating and destinating terminals. It's not the biggest of hubs. Most of the passengers are going to Toronto as opposed to flying off. The idea, over time it will become a bigger hub operation. There are a lot of terminals where the transfer is very high. Little is $O \& D$. (originating and destination)

You fly to Atlanta. Most people are just changing planes and not getting into a car/train. Most people in Denver are transferring and not getting into a car. In Toronto, more people are arriving in Toronto. So, lets say its largely that.

But for me, it is once I get through the process, when I actually feel like I've arrived in Toronto not when I get off the plane. Good Question. Because the issue with Toronto is walking distance.

You have to go a long ways to get to customs and immigration. Especially if you're coming internationally. Where is the sense of arrival? The whole idea of flow, is suppose to be pleasant all the way through the terminal so you have lots of gracious spaces within the terminal and you have lots of natural light when you're going through. It's a self-orienting terminal. But I don't get the feeling that I've arrived, myself, until after I've cleared all my processes. After passport check, customs and Immigration.

The expression used to be when you're leaving a terminal, right, what did you always want to do? Everyone is always very anxious, they're very anxious. Until they actually see their plane at the gate. Once they see their plane at the gate, they know that its there. Then they'll actually relax and they'll even walk back to retail to get a coffee. Up until then, you're kind of nervous. You're kind of anxious. So, l'd say for most people the sense of departure is after the anxiety been relieved.

Even when you're coming back through customs and immigration, even though you might do it every week, you fill out those forms. You want to clear customs and immigration. You're always afraid something is going to happen. Assigned into a flocking room.

In this building type? Yes. So, I have a background between two companies. I was originally from Adamson. I started here as a student in 1977. -30 years. Not bad. But I was gone for a while. While I was gone, I was the partner in charge of design at NORR Partnership Limited. NORR was doing most of the airport work before. So NORR -- which was * terminal one and terminal two. They also had a company called NAPA. Which was NORR Airport Planning Associates, which was the GTAA's planning consultant. I did a lot of terminal work for NORR and NAPA. So I was the principal in charge of design. So I designed most of the terminal complexes. I was heavily involved in the master planning of Pearson and a lot of other airports.

Number one was the existing site conditions. You had three terminals: terminals 1,2 and three. You had all gates occupied and operating. And you had to build a new terminal exactly where the 3 terminals are standing today. So, you had to build first before you could demolish. So,

that was number one. That was the trickiest part.
SEAN: What are the kinds of issues that are significant in that type of building type? 
Number two. Canadian airports are typically more complicated than anybodies airports. We always have three sector terminals and most other airports were two sector - international and domestic. Because of our relationship with the United States we had U.S. pre-clearance, US customs and immigration in Canada. Which meant that we could fly into domestic airports in the states.

So, almost every week I fly down to LaGuardia. When I go to LaGuardia I clear customs here. So when I arrive in LaGuardia I am just a domestic passenger. There is no other process and that made Canadian airports unique. And because of the three sectors, there are three different passenger flows, three different peaks and the terminal building needs to operate differently than two sector terminals.

So there are two parts. One is a major three-sector terminal and the second was building in the middle of an operating existing airport where you couldn't loose any capacity.

SEAN: Airports are certainly circulation. You say airport can be a gateway. What does that mean?

Was their intention, in the Toronto project, to speak of Canada?

When passengers arrive, is the architecture supposed to speak of that a little bit?

SEAN: Can you think of any specific strategies of how the Toronto terminal did that or attempted to do that?

SEAN: Some have said that is the function of the retail component. But I am wondering what can be done architecturally. That is why I ask.
You could say yes. There was some idea that you could make airports regional. Most airports are really international.

You know, the plane that takes off in Thailand has to land in Toronto. The plane that takes off in Singapore has to land in Toronto or Bulgaria of France or England or Denver. The Technology of where you take-off and where you land has to be compatible. And the security where you take off and where you land has to be compatible -- The basic baggage processing and bag readers and card readers. So its participating in a much more international community than a regional one.

And by themselves, airports are not really "national". I mean, they're not really in their character -in their fictional character -- they're not really regional entities. But they can all be adapted to reflect their region. They need to be adapted to reflect a region.

I would actually say the strongest driver of an airport is a set of pragmatics. And then you can adapt it. As opposed to say it is really a local entity that has been altered to accept international technology. I think it is really the opposite. An international entity that will reflect a bit of its surroundings.

We tried a number of ways. If you look at the competition and at the final panels, you'll notice there was a shift in materials. Originally, all the wallwhich became that granite - it meant to be a limestone wall. Because the largest feature in southern Ontario was the escarpment. When you see the competition panels, you'll see everything rendered in limestone. When you see the final building, you'll see everything rendered in granite. Both of them are still intended to be Canadian stone. Whether you're going to the shield, which is north east of Toronto, or whether you're going to the escarpment, which north west of Toronto. That was one.

[pause] What else would be one? [pause]

There was a number of landscape themes because the whole airport was also meant to be an approach into the airport with the whole roadway system coming in at the top and at the side which was meant to be a landscape move. So you're meant to drive through landscape before you hit all the terminals.

Yes, I know the retail intended to be main streets. We were not doing the retail. We accommodate the retail and set guidelines.

But the retail development strategy for the retailers was not us. In the end, do I recognize that retail as Toronto? I don't think so. Does it look that much different than retail in other terminals. l'd say no. 
SEAN: Now in relationship to this idea of border and territory -- Technically you're not in Canada until you've past through customs. And with the US, you've entered the US on Canadian Soil.

SEAN: Could you say then if you're an international traveler and you haven't passed through customs: What is that space?
It's like an embassy. I think, by the time you go through customs and immigration, the floor you're standing on is the equivalent to American Soil.
SEAN: That is probably the most significant criticism of modern airports. They are nowhere lands.

As an architect, do you say that that's deliberate because the nature of the program or is it to try and work to make something more of that space?

TIME 18:00
There used to be a much larger undefined zone between the two sets of control. So people get stuck between the two. It's like getting stuck in purgatory. I think most countries got tired of sending people back (to originating point of embarkation) and having these people in limbo land that now they are quite adamant. You have to be able to make sure you are going to be able to be received in the other country. They will check your passport here just so that when you show up in London you have one. They won't let you on the plane without the ability to enter the next country. Didn't used to be that way. You used to fly there and could claim refugee status or whatever it is, right. You're in Limbo land. Its still there. They try to eliminate part of it. In the American system, there is very little.

Okay, but lets say you go back to an old ship and you were to board a steamer in Rotterdam. And you took that ship to Ellis Island in NY and they turned you down. Aren't you in the same as an airport? The whole ship is that way. Has it ever been any different? I'm not sure it's a new concept or something unique to airports.

- l'd say they've become a lot more pedestrian, a lot more everyday.

That because a lot more people use airports. People used to use ships. The question is whether you would have said the same of a ship or a port? That you could arrive and still not be in a country?

The question is when you're in an airport do you feel you're in a nowhere land or is it a byproduct of a pile of protocols? The Kafka world. We don't really control all aspects.

Don't know if its unique to all airports

Co-mingling is an issue that has been raised with the government a number of times. And, you see, you could say there are different aspects to commingling. Because what you don't want - or what people don't want about to segregate, so explicitly, the different paths of the various passengers. Is there any desire for the co-mingling of passengers?
The threat of terrorism is one set of issues. And that one had to do with 'lack' airports. So, they didn't want somebody getting off in an airport where it was easy to get past scanners. Greece used to be considered a 'lacks' airport. It was easy to board a plane. And you could simply transfer one to the next. Or you could pass something from one guy to the next without entering the country.

So, an inboard international guy is going to meet an outboard international guy and pass him something. And that outboard international guy may be flying to Washington. So the bomb that went from Greece to Canada was never intended for Canada, it was actually intended for Washington. If you allow that to happen, you need to find a way of resolving that one. And it used to be before the terrorist bombs, they would chase the white powder.

Do you want propane coming from Columbia and transferring without 
entering the country? You only get searched or go through the process of search when you pass through the control points. So if you took an airport where they allow people to mix then the bag of propane can come from Columbia go to Miami, meet another guy and end up in a country where there are very little controls. So it wasn't made to prevent the illegal trade. The only reason that 3 sector terminals started up in other countries was because of the common market, right - E.U. You have flights inside the E.U. It's like a domestic flight. I think that's still 2 sector because that's still not international domestic. Its just that domestic is a little bit bigger than the country, you know? It's like a province within a country. So, it's a zone, right? So, say even after $9 / 11$ its become harder to organize commingling. There was always this issue with the states. Why wouldn't they - if your standing on American soil (you go through customs and immigration, you're on American soil) and the guy is coming in from the states. Why can't you meet? Because anything he would have would be presumably - fine.

SEAN: So, it's like a failsafe strategy.

It is. But that's because there are some transit terminals in the states and that is the Achilles heel.

Again, so what would happen is:

If a guy is going to the states and you're going to the states: let's mix. The guy coming from the sates is coming from Miami. But the guy is not actually coming from Miami. He's coming on a Miami flight, but he's actually from Columbia. He's going to Canada and he never entered the states. The issue is you have transfer terminals. So, you're not sure that everyone on that plane is an American. That's the issue.

Everyone takes all the laws and they pull them apart and because you have week links in the airport they don't actually want to actually allow the commingling until the weak links are fixed.

That's my understanding of it.

If you go through the process and everybody's allowed to mix and your going to accept flights from Panama or your going to accept flights from Russia or India, Do you know all those people have been through the same process? That's the problem.

SEAN: How else has security issues shaped the architecture?

TIME 26:00

SEAN: Terminal 1 was a Satellite, then came Terminal 2 - a linear building, then 3 -a pier approach. Is this scheme the one to stay?
Oh, sure. When I was a kid [pause]

When skyjacking came in, security lines first went up. So, there was a lot of middle east skyjacking going on at the time, right. All of a sudden you couldn't walk around [where you used to] That was before the bombs started going on the planes. Security changed a lot of airports.

The technology is going to continue to change. An airport might have a life span of 25 years, maybe 50 years. Scale is constantly changing, modes of transportation is constantly changing.

Modes of transportation will continue to change. Aircraft technology will continue to change. [T1] is designed to accept the new A380. But we don't know what's coming after that. It could go in reverse. You could get smaller planes going point to point.

International laws will change it. Is third time lucky? No. But if you could actually build the infrastructure of the building to accept more change, its got a chance of lasting longer. And hopefully that is what [T1] has. 
check-in, the ticketing area has changed. Will that be seen in new terminal design?

TIME 35:00

SEAN: Airport as city infrastructure. Public Space. Until, recently, delegated to private enterprise. What you begin to see is more retail as well as greater separation between social classes.

SEAN: Recent discussion on whether the A380 can accommodate standing room only. Can designers have the conviction to say no?

TIME 43:00

SEAN: My concern is when you begin to affect the wellbeing of people.

TIME: $45: 00$

SEAN: Any favorite Terminal? character of the main departures hall. Quite a bit.

Yes. Agreed.

Are we building a class system? Ok.

I don't think airports are generating a class system. But I think, yes, we are building a class system. You know [pause] Maybe I'm arguing chicken and egg. But, ah, sure you have those guys who travel and get their lounges and special parking.

Now, if anything, the airport will reflect what's happening in current social environments. I don't think its generating it.

When I was a kid, I traveled on the cheap seats. I was a hitchhiker for a long time. I got no problem with being a hitchhiker.

$I$ also know that if I need to get to a business meeting in Washington tomorrow at noon, I want to be able to get on to that flight. I know I'm willing to pay five times what the hitchhiker is willing to pay.

I don't know if it's wrong. I think it just the way it is. What may appear as a class system may actually be pragmatics.

Yeah, but that's not effecting the well-being of people.

I see now a pattern of pragmatics that I may not agree with but I'm going to say that I need to have them.

The glamour is gone. I'd say that for sure.

Well, Kansai I was excited about.

I fly there a couple of times on purpose.

Once I saw it I was under whelmed. It wasn't the terminal I thought it was going to be.

Fosters in Hong Kong, I liked quite a lot. 


\section{APPENDIX 02.}

Presentation Panels. 

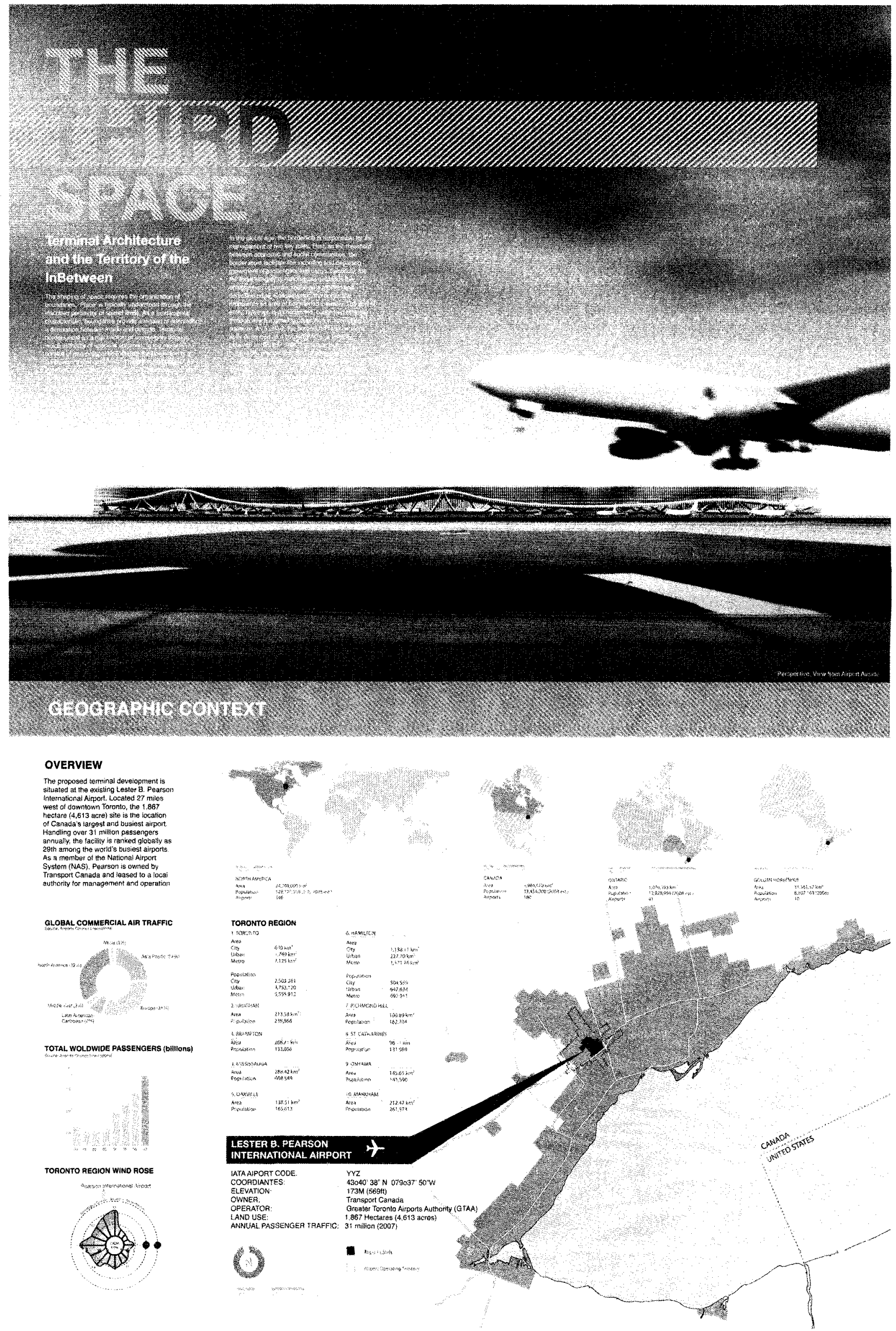




OVERVIEW

To address conceptual and
functionai concsins, the new

Mterna tersinal is

the airsosit lands. For thist tio oceur

the remminal is sopit into two

processor, acts as the magis entry
and intertacs berween terminal and

city-trensport inffastructure. The

seccostd an in-1ied, satelite

pirograminatic elemints stch as boarding facititios and aientational sections are conrected ty a

Concepplually the planning approach

distinguishes beiveen transian

grourtisside systems) ant holt

space (in- itetat torminal). The

Groundside end central processo
reflect their rabituse as inter modal

processing and screening spaces
within a larger networked system

Movements is restrited within a

compreased pouce Users fravel

which is iams and holistic and

autonomous. Festriction is rete

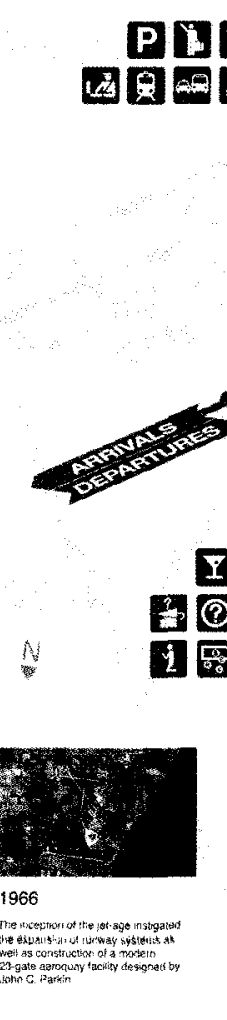

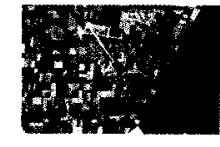

1954

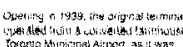






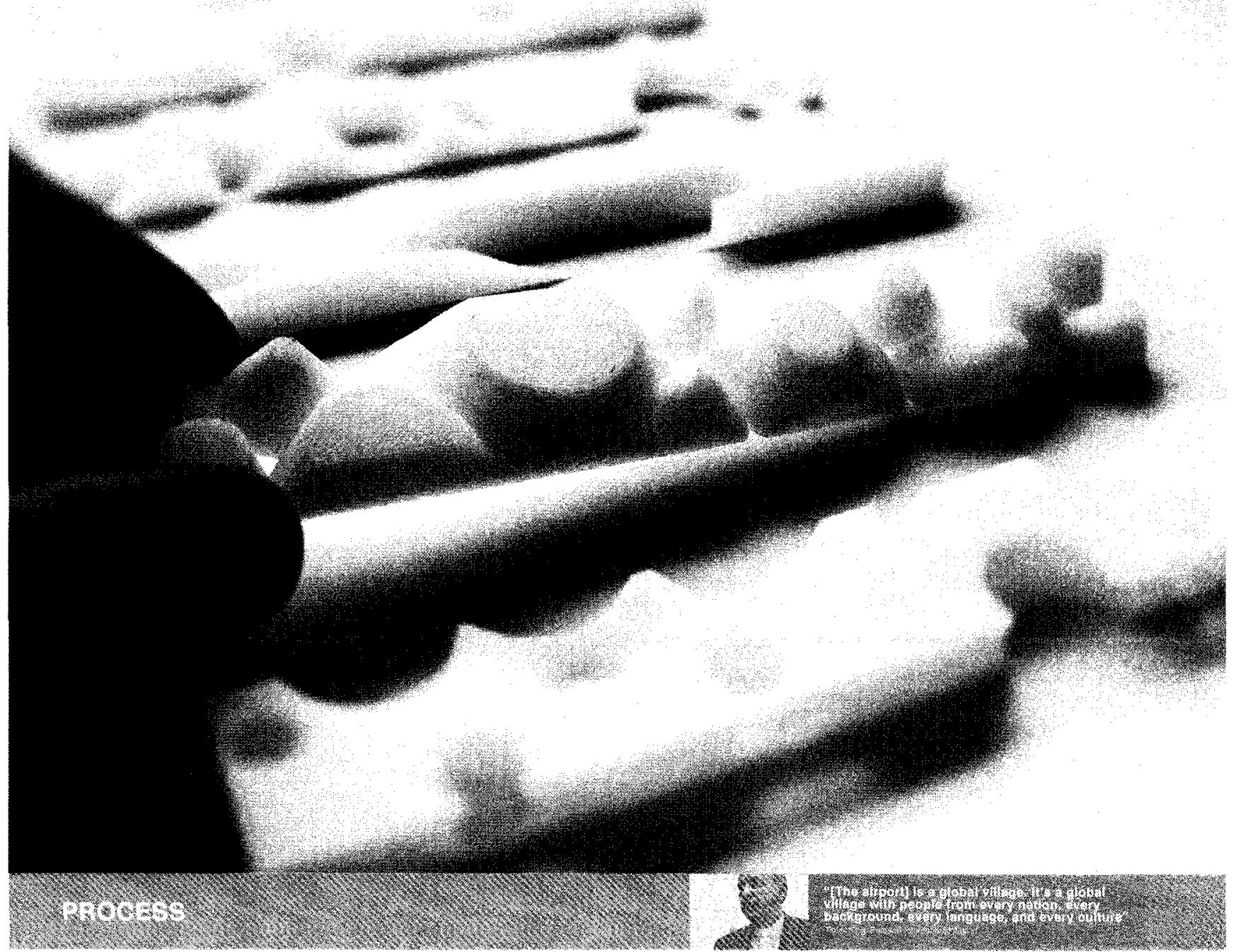

ARCHITECTUAAL PRICIPLES CIRCULATION MODELS



thickened, intersecicid and exparsted to crrate

O2 GENERATE SPAT:ALAND

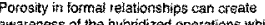

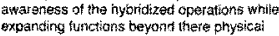

bourdarites

O3 EMBRACE SWOOTH' AND STRIATED
SPACE



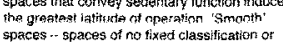

botrndary - inarifest informat axchange while

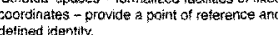

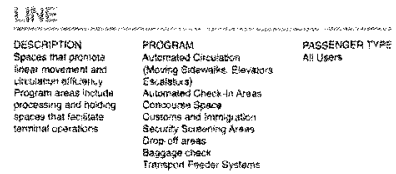

GENERATIVE PROCESSES

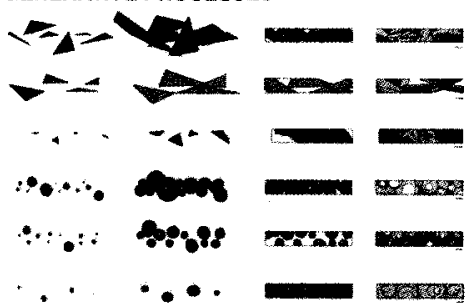

$\therefore-1=0$

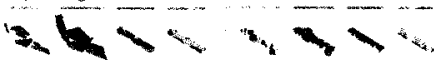

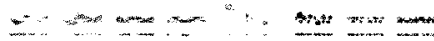

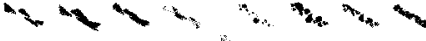

$\because= \pm \quad \cdots \quad \cdots \bar{\nu}$
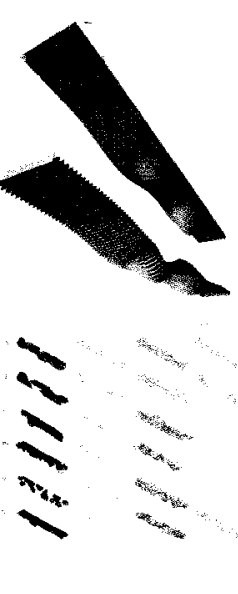

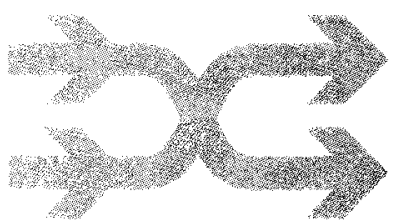

in

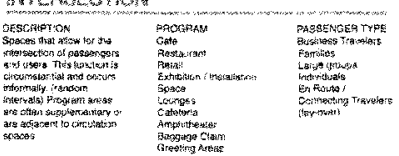

FABRICATION PAOCESSES


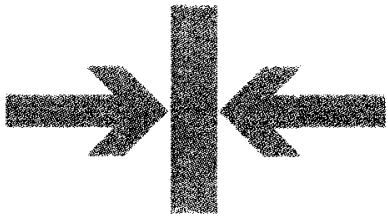

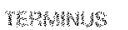



TESTING PROCESSES

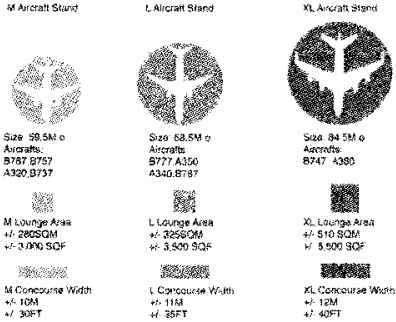

2.

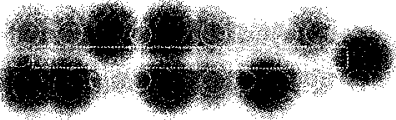






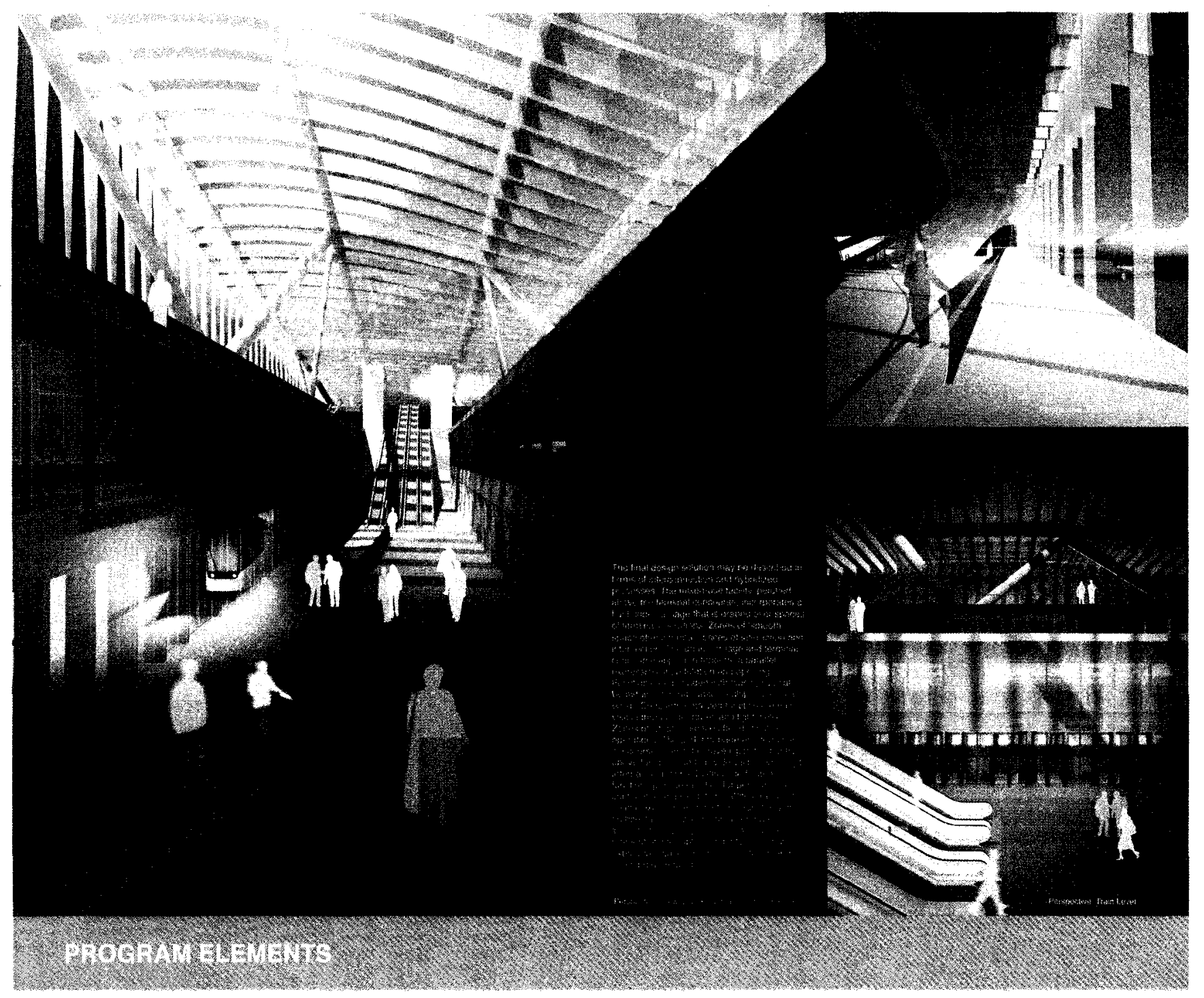

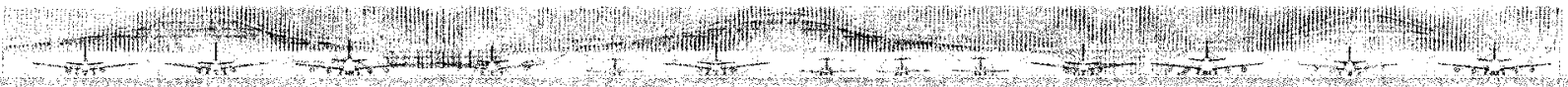

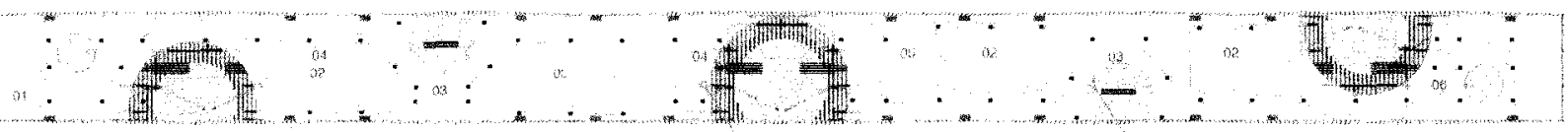

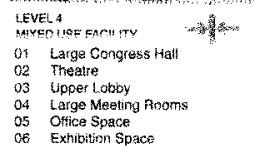

$$
\begin{aligned}
& \text { DEx } \\
& \text { LEVEL3 }
\end{aligned}
$$

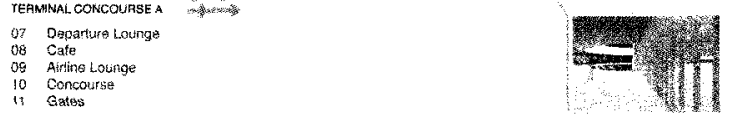

$$
\begin{aligned}
& \text { at }
\end{aligned}
$$

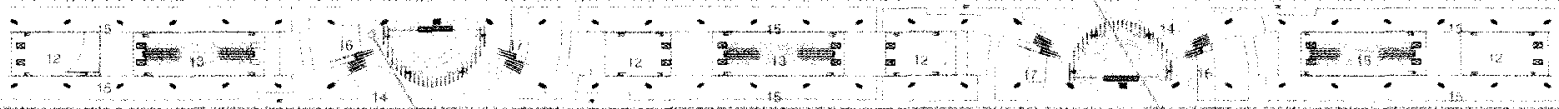

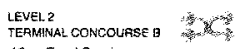

$$
\begin{aligned}
& 18 \text { Ford Strvices } \\
& \begin{array}{l}
\text { Mutt-usa Space } \\
\text { Retail Space }
\end{array} \\
& \begin{array}{l}
16 \text { An Galler } \\
17 \text { Gate }
\end{array}
\end{aligned}
$$



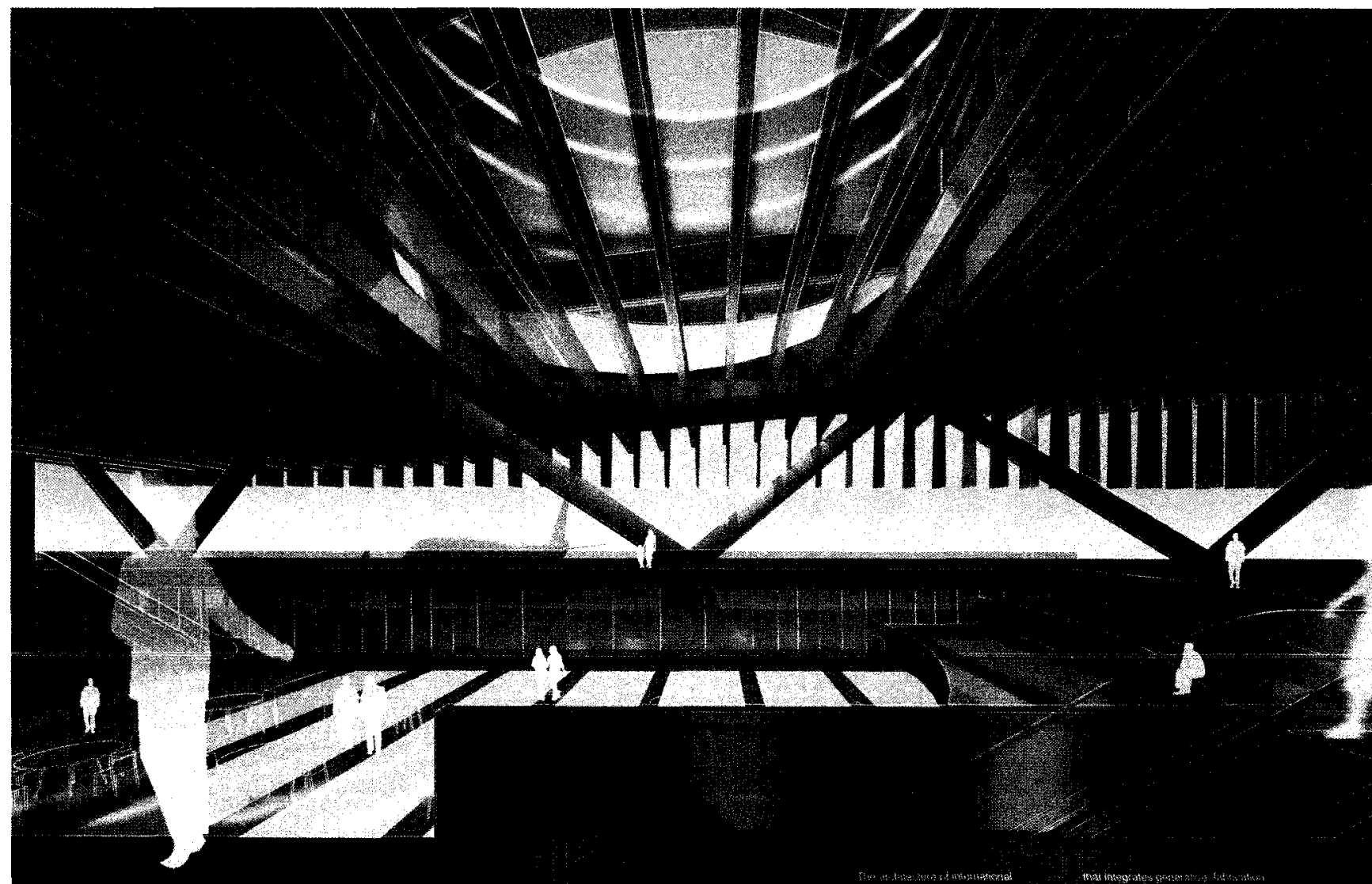

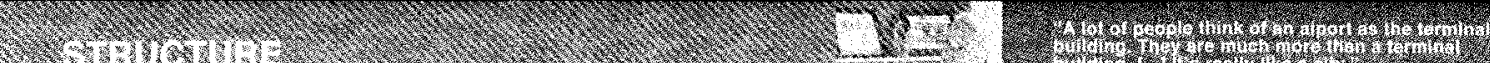

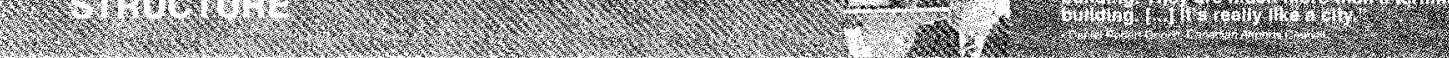
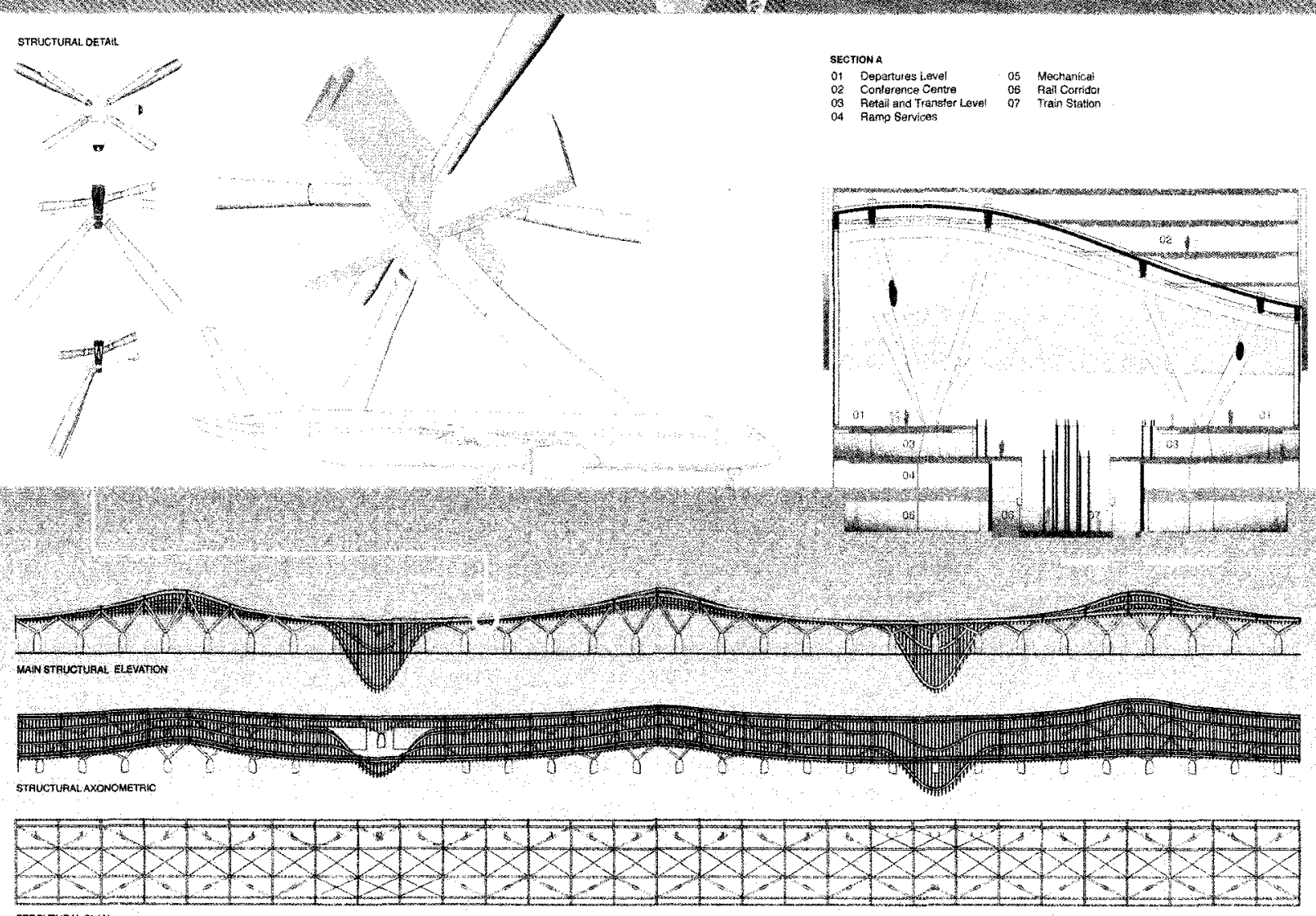